\title{
1993 Annual Report on Alaska’s Mineral Resources
}

\author{
U.S. GEOLOGICAL SURVEY CIRCULAR 1102
}

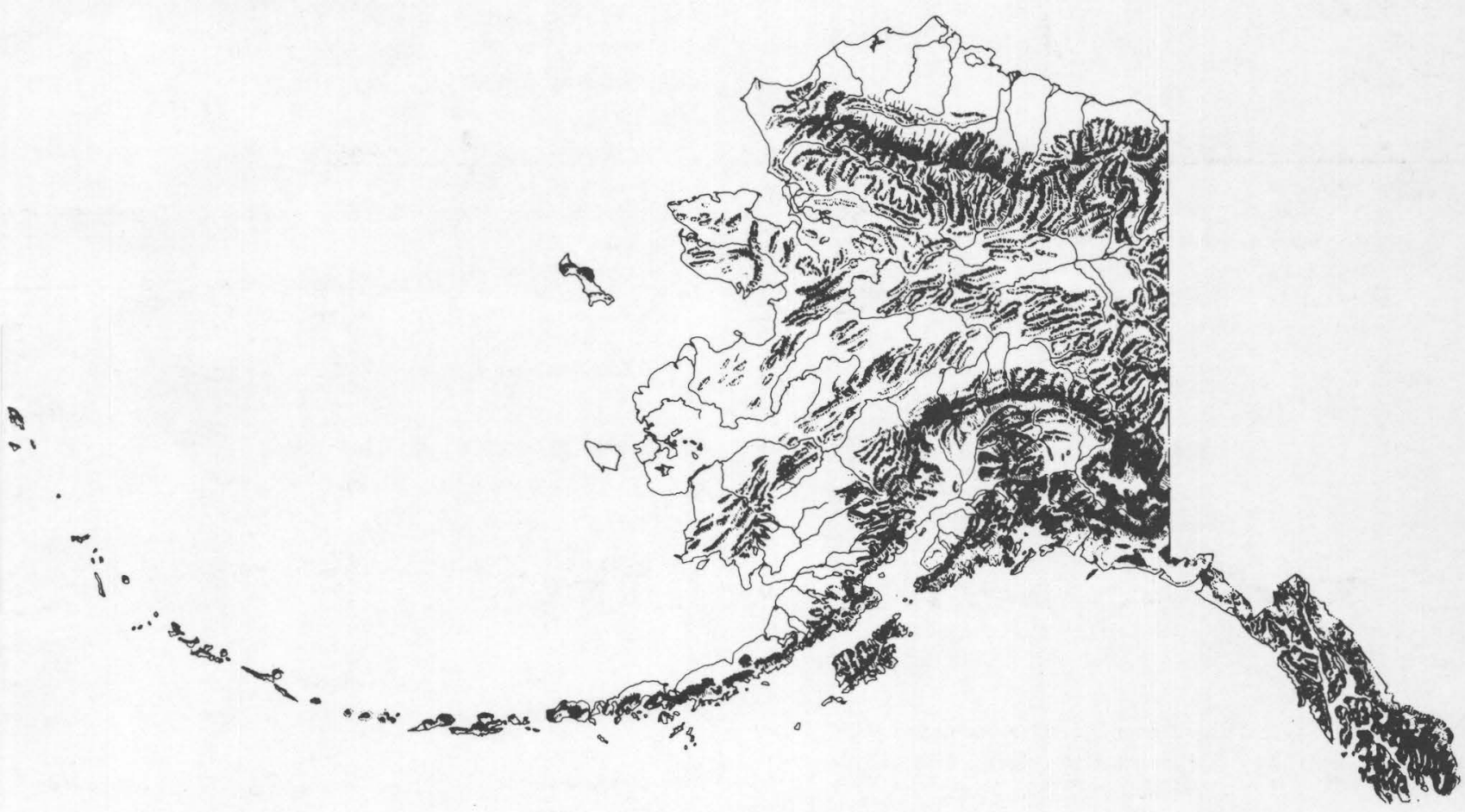

Prepared in cooperation with the Bureau of Land Management, the U.S. Fish and Wildlife Service, the Minerals Management Service, the National Park Service, the U.S. Bureau of Mines, the U.S. Forest Service, and the Department of Energy, as mandated by Section 1011 of the Alaska National Interest Lands Conservation Act, Public Law 96-487, of December 2, 1980

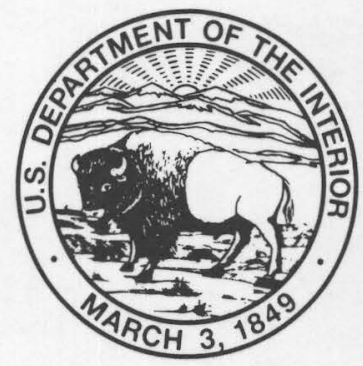




\section{AVAILABILITY OF BOOKS AND MAPS OF THE U.S. GEOLOGICAL SURVEY}

Instructions on ordering publications of the U.S. Geological Survey, along with prices of the last offerings, are given in the currentyear issues of the monthly catalog "New Publications of the U.S. Geological Survey." Prices of available U.S. Geological Survey publications released prior to the current year are listed in the most recent annual "Price and Availability List." Publications that are listed in various U.S. Geological Survey catalogs (see back inside cover) but not listed in the most recent annual "Price and Availability List" are no longer available.

Prices of reports released to the open files are given in the listing "U.S. Geological Survey Open-File Reports," updated monthly, which is for sale in microfiche from the U.S. Geological Survey Books and Open-File Reports Sales, Federal Center, Box 25286, Denver, CO 80225. Reports released through the NTIS may be obtained by writing to the National Technical Information Service, U.S. Department of Commerce, Springfield, VA 22161; please include NTIS report number with inquiry.

Order U.S. Geological Survey publications by mail or over the counter from the offices given below.

\section{BY MAIL}

\section{Books}

Professional Papers, Bulletins, Water-Supply Papers, Techniques of Water-Resources Investigations, Circulars, publications of general interest (such as leaflets, pamphlets, booklets), single copies of periodicals (Earthquakes \& Volcanoes, Preliminary Determination of Epicenters), and some miscellaneous reports, including some of the foregoing series that have gone out of print at the Superintendent of Documents, are obtainable by mail from

\section{U.S. Geological Survey, Books and Open-File Reports Sales \\ Federal Center, Box 25286 \\ Denver, CO 80225}

Subscriptions to periodicals (Earthquakes \& Volcanoes and Preliminary Determination of Epicenters) can be obtained ONLY from the

\section{Superintendent of Documents \\ U.S. Government Printing Office \\ Washington, DC 20402}

(Check or money order must be payable to Superintendent of Documents.)

\section{Maps}

For maps, address mail orders to

\section{U.S. Geological Survey, Map Sales \\ Federal Center, Box 25286 Denver, CO 80225}

Residents of Alaska may order maps from

$$
\begin{aligned}
& \text { U.S. Geological Survey, Map Sales } \\
& 101 \text { Twelfth Ave., Box } 12 \\
& \text { Fairbanks, AK } 99701
\end{aligned}
$$

\section{OVER THE COUNTER}

\section{Books and Maps}

Books and maps of the U.S. Geological Survey are available over the counter at the following U.S. Geological Survey offices, all of which are authorized agents of the Superintendent of Documents.

- ANCHORAGE, Alaska-4230 University Dr., Rm. 101

- LAKEWOOD, Colorado-Federal Center, Bldg. 810

- MENLO PARK, California-Bldg. 3, Rm. 3128, 345 Middlefield Rd.

- RESTON, Virginia-National Center, Rm. 1C402, 12201 Sunrise Valley Dr.

- SALT LAKE CITY, Utah-Federal Bldg., Rm. 8105, 125 South State St.

- SPOKANE, Washington-Rm. 135, U.S. Post Office Bldg., W. 904 Riverside Ave.

- WASHINGTON, D.C.-Main Interior Bldg., Rm. 2650, 18th and C Sts., NW.

\section{Maps Only}

Maps may be purchased over the counter at the U.S. Geological Survey offices:

- FAIRBANKS, Alaska-New Federal Building, 101 Twelfth Ave.

- ROLLA, Missouri-1400 Independence Rd.

- STENNIS SPACE CENTER, Mississippi-Bldg. 3101. 


\section{Annual Report on}

Alaska's Mineral Resources 


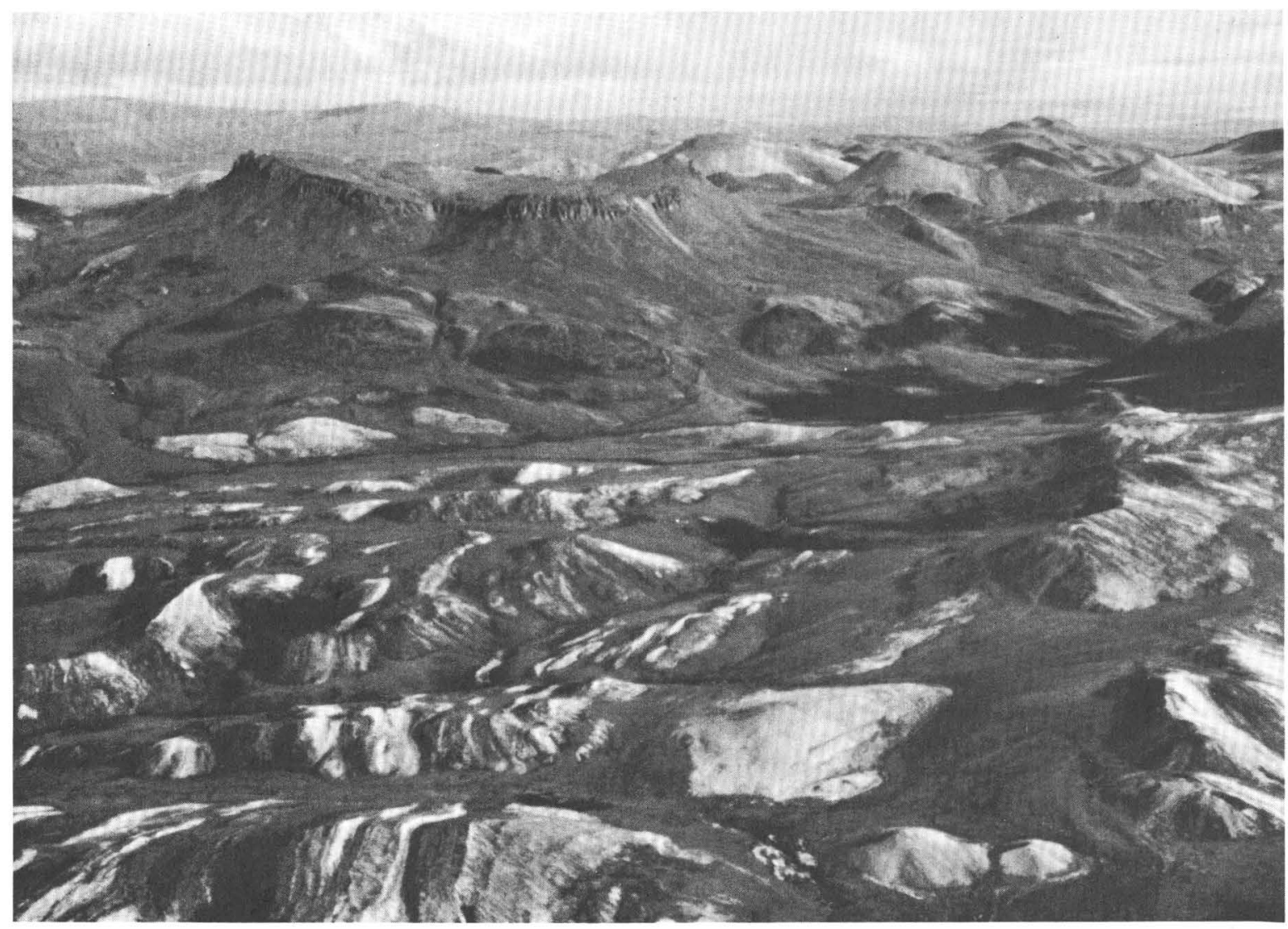

Frontispiece. Cutaway Creek area in the northern foothills of the central Brooks Range. USBM, USGS, and BLM geologists are studying the oil, gas, and mineral-resource potential of this area under several agency and inter-agency programs. The mineralresource data for the area's Colville mining district will be incorporated into the BLM's Arctic District Land Management Plan. Photograph by J. Dumoulin. 


\title{
1993 Annual Report on Alaska's Mineral Resources
}

\author{
JILL L. SCHNEIDER, Editor
}

\section{U.S. GEOLOGICAL SURVEY CIRCULAR 1102}

Prepared in cooperation with the Bureau of Land Management, the U.S. Fish and Wildlife Service, the Minerals Management Service, the National Park Service, the U.S. Bureau of Mines, the U.S. Forest Service, and the Department of Energy, as mandated by Section 1011 of the Alaska National Interest Lands Conservation Act, Public Law 96-487, of December 2, 1980

A summary of mineral resource activities in Alaska during 1992 


\title{
U.S. DEPARTMENT OF THE INTERIOR \\ BRUCE BABBITT, Secretary
}

\author{
U.S. GEOLOGICAL SURVEY
}

Robert M. Hirsch, Acting Director

Free on application to the

Book and Open-File Report Sales

U.S. Geological Survey

Federal Center, Box 25286

Denver, CO 80225 


\section{CONTENTS}

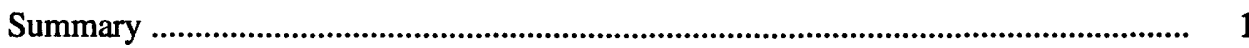

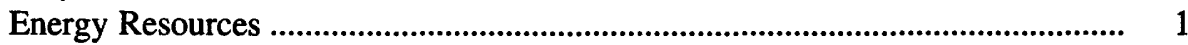

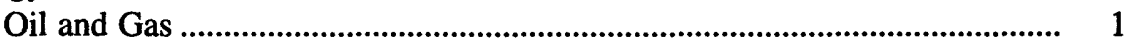

Arctic National Wildlife Refuge ............................................................ 2

Exxon Valdez Oil Spill ........................................................................... 2

Coal and Peat ................................................................................................... 2

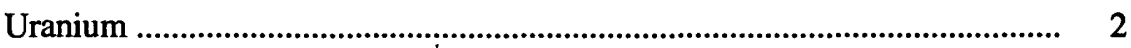

Geothermal Resources ............................................................................... 3

Nonfuel-Mineral Resources .......................................................................... 3

Metallic Minerals .............................................................................................. $\quad 3$

Industrial Minerals ................................................................................ 4

Introduction .................................................................................................. 4

Mineral Programs ....................................................................................... 4

Department of the Interior ................................................................................... 4

U.S. Geological Survey ................................................................................ 4

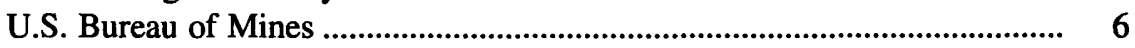

Minerals Management Service ................................................................. 7

Bureau of Land Management ................................................................... 8

U.S. Fish and Wildlife Service ................................................................ 8

National Park Service ............................................................................. 9

Department of Agriculture ..................................................................... 11

U.S. Forest Service ............................................................................... 11

Department of Energy ................................................................................... 11

Contacts for Further Information ................................................................. 11

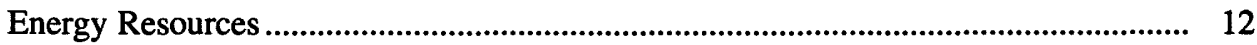

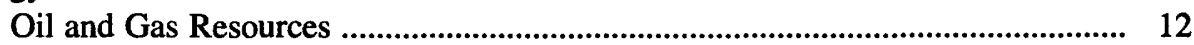

Overview of Production and Prices ......................................................... $\quad 12$

Exploration .......................................................................................................... 12

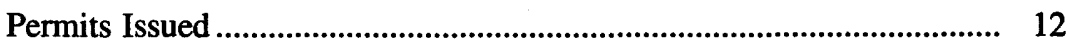

Drilling Activity ........................................................................................ 12

Geophysical Surveys .............................................................................. 13

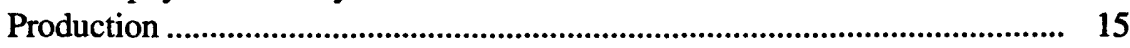

North Slope ....................................................................................... 15

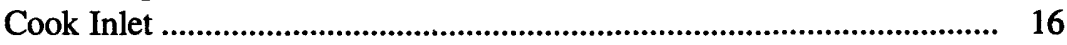

Lease Sales......................................................................................................... 16

Transportation ............................................................................................... 16

Activity by Federal Agencies ........................................................................... 17

Minerals Management Service ........................................................... 17

Leasing and Exploration Activity ............................................... 17

Future Lease Sales ................................................................... 20

Oil and Gas Resource Assessment ............................................ 21

Data Acquisition on the Alaskan OCS ......................................... 21

Joint Federal-State Studies .......................................................... 21

Environmental Studies Program .................................................. 21

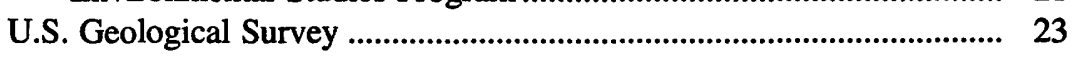

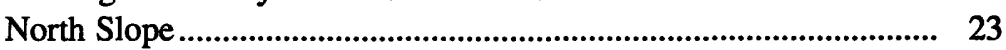

Interior Alaska ........................................................................... 23

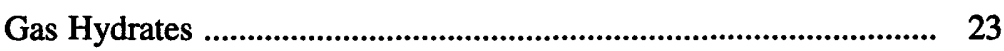

Thermal-Maturity Map of Alaska ................................................. 24

Oil and Gas Resource Assessment ................................................ 25

Bureau of Land Management ............................................................. 25 
Energy Resources-Continued

Oil and Gas Resources-Continued

Activity by Federal Agencies-Continued

U.S. Fish and Wildlife Service ........................................................ 26

Kenai National Wildlife Refuge .............................................. 26

Activities Under Section 1008 of ANILCA ................................... 26

Resource Activity Impact Assessment ........................................... 26

National Park Service ............................................................................ 27

Department of Energy ............................................................................ 27

Arctic National Wildlife Refuge ................................................................. 27

Activity by Federal Agencies ................................................................. 29

U.S. Fish and Wildlife Service .................................................... 29

Exxon Valdez Oil Spill ........................................................................ 29

Activity by Federal Agencies .................................................................. 29

U.S. Fish and Wildlife Service ..................................................... 29

Minerals Management Service .................................................... $\quad 30$

National Park Service .................................................................. $\quad 30$

U.S. Geological Survey .......................................................... 30

Coal and Peat Resources ............................................................................. 30

Overview of Industry Activity ................................................................. $\quad 30$

Activity by Federal Agencies ……................................................................. 33

U.S. Geological Survey .................................................................. 33

Bureau of Land Management ............................................................. 33

Department of Energy ........................................................................ 33

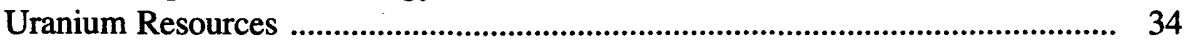

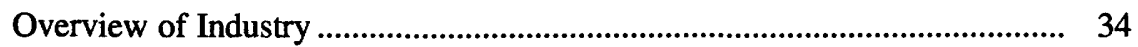

Activity by Federal Agencies ................................................................ 34

U.S. Geological Survey ........................................................................ 34

U.S. Fish and Wildlife Service .......................................................... 34

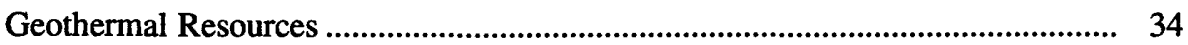

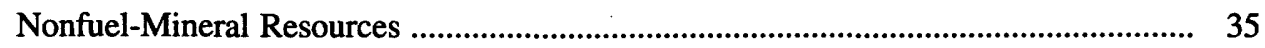

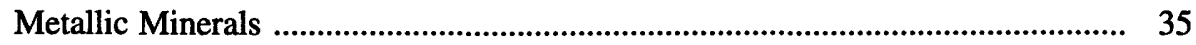

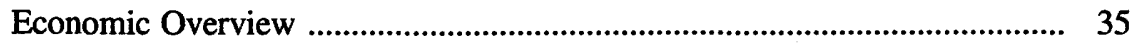

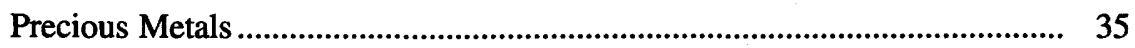

Other Metals ................................................................................................. 39

Activity by Federal Agencies .................................................................... 40

U.S. Geological Survey .................................................................... 40

Alaska Mineral Resource Assessment Program .............................. 40

Precious Metals ........................................................................... 43

Strategic and Critical Minerals .................................................... 43

Other Metals ............................................................................ 43

Statewide Mineral-Resource Assessment ......................................... 44

Cooperative Programs with Foreign Scientific Agencies ................. 44

Trans-Alaska Crustal Transect ........................................................... 45

National Petroleum Reserve-Alaska ............................................ 45

U.S. Bureau of Mines ....................................................................... 46

Minerals Availability Program ...................................................... 46

Policy Analysis .................................................................... 46

State Mineral Activities ............................................................ 47

Mineral Land Assessment .............................................................. 47

Mining Research .................................................................... $\quad 50$

Bureau of Land Management ................................................................. 51

U.S. Fish and Wildlife Service ....................................................... 51

Minerals Management Service ................................................................. 51

National Park Service ....................................................................... 52 
Non-Fuel Mineral Resources-Continued

Metallic Minerals-Continued

Activity by Federal Agencies-Continued

U.S. Forest Service 54

Tongass National Forest ............................................................ 54

Chugach National Forest ........................................................... 54

Industrial Minerals .......................................................................................... 55

Overview of Industry Activity ...................................................................... 55

Activity by Federal Agencies ....................................................................... 55

Bureau of Land Management ........................................................... 55

U.S. Fish and Wildlife Service .......................................................... 55

U.S. Forest Service ........................................................................... 56

References Cited .................................................................................................. 56

Appendix 1. Alaska Mineral Reports Released During 1992 and Early 1993............ 58

Department of the Interior .................................................................................. 58

U.S. Geological Survey ................................................................................ 58

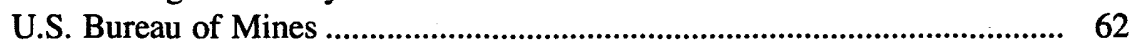

Minerals Management Service .................................................................... 63

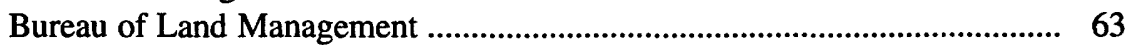

U.S. Fish and Wildlife Service ..................................................................64

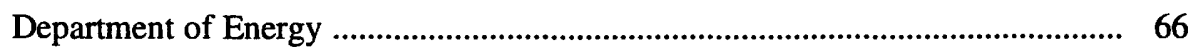

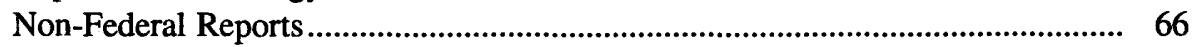

Alaska Division of Geological and Geophysical Surveys ............................... 66

Additional Non-Federal Publications ............................................................. 66

Appendix 2. Roles of Federal Agencies in Mineral Programs .................................... 67

Department of the Interior ............................................................................... 67

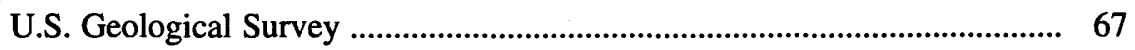

U.S. Bureau of Mines ................................................................................ 68

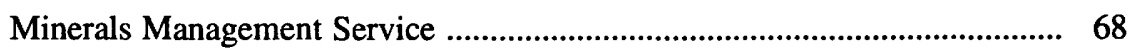

Bureau of Land Management ................................................................. 69

U.S. Fish and Wildlife Service .................................................................. 69

National Park Service .................................................................................. 69

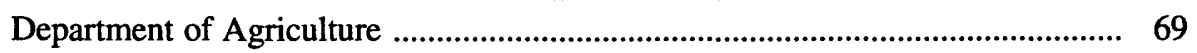

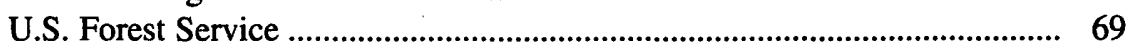

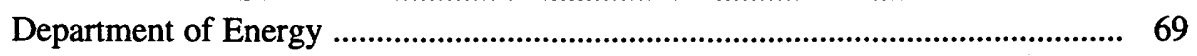

\section{FIGURES}

Frontispiece. Photograph of Cutaway Creek area in the northern foothills of the central Brooks Range ....................... II

1. Map of Federal land ownership in Alaska ....................................................................................... 5

2-4. Photographs showing:

2. USGS scientist collecting pan-concentrate sample for geochemical analysis ................................... 6

3. Pegmatite in southeastern Alaska being evaluated by the USBM for its mineral-resource potential ... 7

4. Helicopter used by Federal and State geologists for access to remote field sites in the Colville mining district

5-8. Maps showing:

5. National wildlife refuges in Alaska

6. Locations of exploratory oil wells drilled in 1992, oil and gas fields, and possible petroleumbearing sedimentary basins

7. Alaska Outer Continental Shelf Region planning areas and lease sale history .

8. Areas proposed by the MMS for future lease sales or geological and environmental studies, 1992-1997.

9. Photograph showing outcrop of Lisburne Group in the Ivotuk Hills, Killik River quadrangle. 
10-12. Maps showing:

10. Onshore favorable petroleum provinces, land units referred to in text, and locations of DOE-funded research in 1992

11. Areas of potential coal, uranium, and geothermal resources mentioned in text

12. Areas of significant industry activity involving metallic minerals (excluding uranium) in 1992, and mine and deposit locations referred to in text

13. Photograph showing gold-placer dredge in Chicken Creek, Fortymile mining district

14. Photograph showing abandoned workings of the A-J Mine on hillside above downtown Juneau .............. 39

15. Map showing status of USGS level III AMRAP quadrangle studies as of January 1993 ......................... 41

16. Map showing locations of USGS level IV AMRAP metallic-mineral and TACT studies in 1992........... 42

17. Photograph showing Stack barite deposit in central Howard Pass quadrangle ........................................... 45

18. Map showing locations of 1992 U.S. Bureau of Mines study areas listed in table 9 ............................... 48

19-21. Photographs showing:

19. Spiral separator used to concentrate heavy minerals in beach sands at Cape Yakataga ...................... 50

20. NPS personnel reviewing plan of operations in Bering Land Bridge National Park and Preserve ...... 53

21. USBM scientist inspects oil-filled electrical transformer at an abandoned mine in the Chugach National Forest

\section{TABLES}

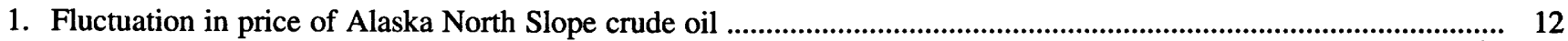

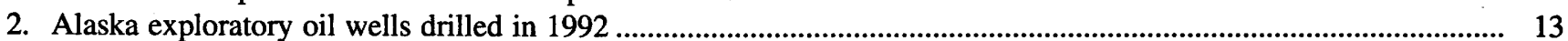

3. Alaska Outer Continental Shelf leases and wells drilled, 1976-1992 .................................................................. 19

4. Proceeds from lease sales on Alaska Outer Continental Shelf planning areas ........................................................ 19

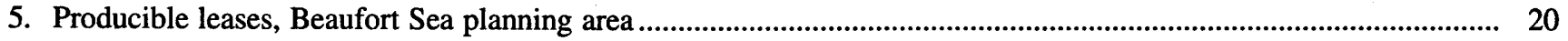

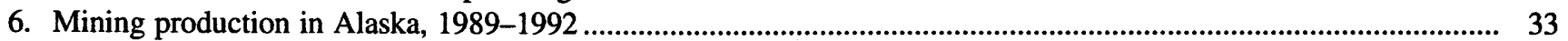

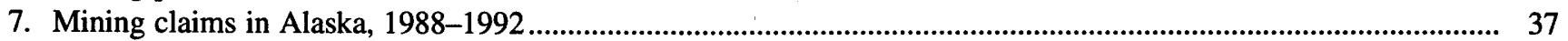

8. Level IV studies of the U.S. Geological Survey Alaska Mineral Resource Mineral Resource Assessment Program and related projects active in 1992

9. U.S. Bureau of Mines study areas in 1992

\section{ACRONYMS AND ABBREVIATIONS}

$\begin{array}{ll}\text { ACE } & \text { U.S. Army Corps of Engineers } \\ \text { ADGGS } & \text { Alaska Division of Geological and Geophysical Surveys } \\ \text { AFOC } & \text { Alaska Field Operations Center } \\ \text { AIDEA } & \text { Alaska Industrial Development and Export Authority } \\ \text { A-J } & \text { Alaska-Juneau } \\ \text { AMHL } & \text { Alaska Mental Health Lands } \\ \text { AML } & \text { Abandoned Mineral Lands } \\ \text { AMRAP } & \text { Alaska Mineral Resource Assessment Program } \\ \text { ANGTS } & \text { Alaska Natural Gas Transportation System } \\ \text { ANILCA } & \text { Alaska National Interest Lands Conservation Act } \\ \text { ARCO-AK } & \text { ARCO Alaska } \\ \text { ARDF } & \text { Alaskan Resource Data File } \\ \text { bbl/d } & \text { barrels of oil per day } \\ \text { BEST } & \text { Biomonitoring of Environmental Status and Trends } \\ \text { BLM } & \text { Bureau of Land Management } \\ \text { Btu } & \text { British thermal unit } \\ \text { C } & \text { Celsius } \\ \text { CFR } & \text { Code of Federal Regulations } \\ \text { CIRI } & \text { Cook Inlet Region Incorporated } \\ \text { DOE } & \text { Department of Energy } \\ \text { DOI } & \text { Department of the Interior } \\ \text { DST } & \text { deep stratigraphic test } \\ \text { EIS } & \text { environmental impact statement } \\ \text { EPA } & \text { Environmental Protection Agency } \\ & \end{array}$




$\begin{array}{ll}\text { ESP } & \text { Environmental Studies Program } \\ \text { F } & \text { Fahrenheit } \\ \text { FWS } & \text { Fish and Wildlife Service } \\ \text { g/t } & \text { grams per metric ton } \\ \text { GVEA } & \text { Golden Valley Electric Association } \\ \text { I\&E } & \text { Inspection and Enforcement } \\ \text { JPO } & \text { Joint Pipeline Office } \\ \text { LNG } & \text { liquefied natural gas } \\ \text { MAS } & \text { Minerals Availability System } \\ \text { MCIS } & \text { Mineral Claim Information System } \\ \text { MILS } & \text { Minerals Industry Location System } \\ \text { MMS } & \text { Minerals Management Service } \\ \text { MRDS } & \text { Mineral Resources Data System } \\ \text { NEPA } & \text { National Environmental Policy Act } \\ \text { NOAA } & \text { National Oceanic and Atmospheric Administration } \\ \text { NP\&P } & \text { National Park and Preserve } \\ \text { NPRA } & \text { National Petroleum Reserve-Alaska } \\ \text { NPS } & \text { National Park Service } \\ \text { NSRC } & \text { North Slope Regional Corporation } \\ \text { NURE } & \text { National Uranium Resource Evaluation } \\ \text { NWR } & \text { National Wildlife Refuge } \\ \text { OCS } & \text { Outer Continental Shelf } \\ \text { PCB } & \text { polychlorinated biphenyls } \\ \text { PGM } & \text { platinum-group metal } \\ \text { ppm } & \text { parts per million } \\ \text { RCRA } & \text { Resource Conservation and Recovery Act } \\ \text { REE } & \text { rare-earth elements } \\ \text { SAMRAP } & \text { State of Alaska Mineral Resource Assessment Program } \\ \text { SCRMP } & \text { Studies Related to Continental Margins Program } \\ \text { SESU } & \text { Social and Economic Studies Unit } \\ \text { TACT } & \text { Trans-Alaska Crustal Transect } \\ \text { TAGS } & \text { Trans-Alaska Gas System } \\ \text { TAPS } & \text { Trans-Alaska Pipeline System } \\ \text { USBM } & \text { U.S. Bureau of Mines } \\ \text { USCG } & \text { U.S. Coast Guard } \\ \text { USFS } & \text { U.S. Forest Service } \\ \text { USGS } & \text { U.S. Geological Survey } \\ \text { USSR } & \text { Union of Soviet Socialist Republics, now defunct } \\ & \end{array}$

\section{INTERNATIONAL SYSTEM OF UNITS (SI) CONVERSION TABLE ${ }^{1}$}

\begin{tabular}{llc}
\hline To convert from & to & divide by \\
\hline cubic meter & barrel (oil) & 0.1589873 \\
cubic meter & cubic foot (gas) & 0.02831685 \\
cubic meter & cubic yard & 0.7645549 \\
degree Celsius & degree Fahrenheit & $t{ }^{\circ} \mathrm{F}=32+\left(1.8 \times t^{\circ} \mathrm{C}\right)$ \\
gram & troy ounce & 31.10348 \\
joule per kilogram & Btu per pound & 2324.444 \\
meter & foot & 0.3048 \\
meter & inch & 0.0254 \\
kilogram & pound & 0.4535924 \\
kilogram & troy ounce & 0.03110348 \\
kilometer & mile & 1.609347 \\
metric ton & ton (short) & 0.9071847 \\
square kilometer & acre & 0.004046873 \\
square kilometer & square mile & 2.589998 \\
\hline
\end{tabular}

${ }^{1}$ American Society for Testing and Materials (1980) 


\title{
CONTRIBUTORS
}

\section{DEPARTMENT OF THE INTERIOR}

\author{
Bureau of Land Management \\ Gary Brougham \\ Joseph Dygas \\ Nolan Heath \\ Ruth Stockie
}

\section{U.S. Fish and Wildlife Service Jerald Stroebele \\ Minerals Management Service Richard Newman}

National Park Service

Judith Alderson

\section{U.S. Bureau of Mines Steven Fechner}

\section{U.S. Geological Survey}

Kenneth Bird

Diedra Bohn

Kendell Dickinson

John Galloway

Jill Schneider

Gary Stricker

Ellen White

\section{DEPARTMENT OF AGRICULTURE}

U.S. Forest Service Roger Griffin

\section{DEPARTMENT OF ENERGY}

\section{Steven Heintz}

Rod Malone

Harold Shoemaker 


\title{
1993 Annual Report on Alaska's Mineral Resources
}

\author{
Jill L. Schneider, Editor
}

\section{SUMMARY}

Section 1011 of the Alaska National Interest Lands Conservation Act (ANILCA) of 1980 requires that "On or before October 1, 1982, and annually thereafter, the President shall transmit to Congress all pertinent public information relating to minerals in Alaska gathered by the United States Geological Survey, Bureau of Mines, and any other Federal agency." This report has been prepared in response to that requirement.

This circular is the twelfth in a series of annual ANILCA reports. The report provides information about current Alaskan mineral projects and events during 1992; the emphasis is on Federal activity. The report addresses both onshore and offshore areas of Alaska.

The U.S. Geological Survey (USGS), U.S. Bureau of Mines (USBM), and Minerals Management Service (MMS) are the principal Federal agencies that publish information about energy and mineral resources in Alaska. Their reports and data form the basis for decisions by other Federal agencies regarding land use, access, environmental impacts, and mining claim evaluation. The time required for sample analysis, data synthesis, and publication is lengthy; as a result, scientific reports are generally issued a year or more after initial sample and data collection. Other sources of information for this report include additional Federal and State publications, trade and professional journals, newspaper articles, presentations at public meetings and hearings, and press releases.

Information is provided for two broad categories of minerals: energy resources and nonfuel-mineral resources.

\section{ENERGY RESOURCES}

\section{OIL AND GAS}

Alaskan oil production in 1992 totaled 654 million barrels of oil and natural-gas liquids, down 3.8 percent from the previous year. Apart from a small increase in 1991, annual oil production in Alaska has declined since the peak level of 738 million barrels in 1988. Alaska

Manuscript approved for publication September 20, 1993. provided 25 percent of total United States oil production in 1992. Dry natural gas production in 1992 rose 1 percent to 5.7 billion cubic meters. North Slope oil prices during the year averaged $\$ 17.32$ per barrel (West Coast), a 3.6-percent decline from the previous year. Prices per barrel ranged from a low of $\$ 14.84$ in January to a high of $\$ 20.20$ in July.

The Alaska Oil and Gas Conservation Commission issued 153 drilling permits in 1992, slightly down from the 157 permits issued in 1991. A total of 16 exploratory wells were active. Three oil discoveries in northern Alaska were announced: two in the Colville River Delta region and one in the eastern Beaufort Sea. A fourth discovery was confirmed in the Cook Inlet region. The State of Alaska held three lease sales on and offshore of the North Slope; high bonus bids for two of the sales totaled over $\$ 12$ million for 101 tracts covering 1,560 square kilometers. No Federal lease sales were held during 1992.

The MMS prepared a 5-year comprehensive program for the management and leasing of natural gas and oil on the Alaskan Outer Continental Shelf (OCS); six lease sales are planned for 1994-1997. The MMS issued permits for 2,832 kilometers of seismic surveys in OCS waters in 1992. Cooperative studies in 1992 by the MMS and the Alaska Division of Geological and Geophysical Surveys (ADGGS) focused on the Prudhoe Bay area, the foothills of the Arctic National Wildlife Refuge (Arctic NWR), and the western front of the Brooks Range. Continued environmental studies on the OCS emphasized possible environmental effects following exploration activities and oil and gas drilling.

In 1992, the USGS continued its evaluation of oil potential on the North Slope and in the Kandik basin of eastcentral Alaska, and of the energy potential of the Nenana basin. The USGS also continued to investigate the potential production of gas from hydrate complexes, completed a generalized thermal-maturity map of Alaska, and released additional details of the 1987 national oil and gas assessment.

The Bureau of Land Management (BLM) completed a resource assessment in the Forty Mile/Black River planning area and completed oil and gas assessments in the Utukok and Teshekpuk Lake Special Areas of the National Petroleum Reserve-Alaska (NPRA). In addition, the BLM continued to work toward a possible oil and gas lease sale 
in NPRA and completed several oil and gas appraisals for land-exchange parcels. Other ongoing activities include North Slope mineral assessment, mining claim patent evaluation, and oil and gas lease management. The BLM continued its Alaska Inspection and Enforcement program for leasehold oil and gas operations on producing Federal leases in the Cook Inlet Basin. Through the Joint Pipeline Office, the BLM monitors the Trans-Alaska Pipeline System in cooperation with seven other Federal and State agencies.

Minerals-related activities for the U.S. Fish and Wildlife Service (FWS) during 1992 included environmental monitoring, permit review and comment, and contaminant analysis both on and off refuges. On refuges, the FWS maintained oversight for remedial cleanup programs and issued special use permits for exploration and development activities. The FWS reviewed 23 permit applications for oil and gas activities off refuges and issued 17 special-use permits for activities on refuges. One Federal OCS environmental impact statement and 14 State oil and gas lease sales were reviewed.

In 1992, the National Park Service (NPS) commented on oil and gas lease sales scheduled near national park units. The Department of Energy (DOE) continued to study the applicability of recovery techniques to gashydrate reservoirs in the Arctic.

\section{ARCTIC NATIONAL WILDLIFE REFUGE}

The FWS and BLM continued to respond to public and congressional inquiries regarding the resource potential and likely impacts to surface resources in the ANILCA 1002 area, a 6,070-square-kilometer strip within the coastal plain of the Arctic NWR. While visits to the area by congressional and industry groups were numerous in 1991, there were few such visits in 1992. BLM geologists and geophysicists reviewed all geoscience information pertinent to Arctic NWR. The FWS completed the fifth year of its 5-year continuing studies in the 1002 area, inventorying the vegetation, water availability, birds, mammals, and fish, in order to better understand the area's ecosystem. This knowledge will be used to avoid, minimize, or rectify adverse impacts from oil drilling, if drilling should occur in the 1002 area.

\section{EXXON VALDEZ OIL SPILL}

The oil tanker T/V Exxon Valdez ran aground on Bligh Reef on March 24, 1989, spilling more than 41,640 cubic meters $(262,000$ barrels) of Prudhoe Bay crude oil into eastern Prince William Sound. Containment efforts failed, and the oil eventually spread south and west as far as the Alaska Peninsula. In October 1991, the Exxon Corporation and Exxon Shipping Company agreed to pay a record $\$ 1.025$ billion in fines, restitution, and civil damages to the Federal and State governments. Federal and State agencies continue to monitor and assess the long-term impact of the oil spill.

During the fourth year following the Exxon Valdez oil spill, the FWS remained actively involved in response activities, assessing the status of national wildlife refuge shorelines, monitoring cleanup activities, and protecting Department of the Interior (DOI) trust resources. The FWS also continued its Natural Resource Damage Assessment and Restoration Planning activities on migratory birds and sea otters, those species most severely impacted by the spill.

The MMS provided staff and some funding to assist in the cleanup and monitoring of the oil spill. In 1992, MMS researchers continued to collect information on the longterm social, economic, and cultural consequences of the spill.

Since the oil-spill litigation in 1991, the NPS has continued its active involvement in restoration planning and implementation of the settlement agreement. An oilpersistence survey conducted by the NPS showed small amounts of oil remaining at more than 20 locations within the three parks affected by the spill.

In order to track oil from the spill, the USGS collected and analyzed sediment samples from beaches, nearshore environments, and deep-water sites in Prince William Sound. Results indicate that oil found in the beach and nearshore sediments is chemically comparable to Exxon Valdez oil. Possible oil contamination was also found in five deep-water sites.

\section{COAL AND PEAT}

Alaskan coal production fell slightly to 1.39 million metric tons, valued at $\$ 38.3$ million. At present, all production comes from the Usibelli Mine in central Alaska; however, in 1992, the North Slope's Aluaq Mine produced 680 metric tons on an exploration permit. Development of the Healy Clean Coal Project is moving forward. Peat production, valued at $\$ 400,000$, was down almost 7 percent in 1992.

USGS researchers sampled and studied coals on the Kenai Peninsula and analyzed samples from the Usibelli coal mine in central Alaska. The BLM continued its assessment of the coal potential of NPRA as part of the joint USBM-USGS-BLM Colville mining district study, and also continued its management of the Jarvis Creek coal lease near Delta Junction. The DOE prepared an environmental impact statement for the Healy Project.

\section{URANIUM}

Alaska's uranium resources remain undeveloped owing to low market value coupled with high exploration and development costs. USGS uranium research continued at a 
low level; most of the activity relates to previously collected data. The USGS published a report in 1992 describing uranium distribution on the Kenai Peninsula.

At Cape Thompson, the Alaska Maritime NWR placed warning signs for possible radiation-contamination hazards and, in cooperation with the DOE, began scoping the level of effort required to assess and remediate nuclear contaminants at the former Project Chariot site.

\section{GEOTHERMAL RESOURCES}

Geothermal resources in Alaska are associated with the widespread, young volcanic activity in the south-central part of the State. No Federal geothermal research was funded for Alaska.

\section{NONFUEL-MINERAL RESOURCES}

\section{METALLIC MINERALS}

The value of Alaska's metallic mineral production rose by 4 percent in 1992 to $\$ 457$ million, in spite of depressed metal prices; development expenditures rose 16 percent to $\$ 29.6$ million. Exploration outlays declined 24 percent to $\$ 30.4$ million. Zinc production produced the most revenue at $\$ 302$ million for 248,978 metric tons; gold, silver, and lead are the other main metals produced in Alaska. Alaska supplied approximately 50 percent of the United States zinc production in 1992, plus 17 percent of the silver and 12 percent of the lead. The Kennecott Greens Creek silver-lead-zinc mine closed in early 1993 due to low metal prices.

The number of active mineral properties in Alaska fell 13 percent from 1991 levels to 29,116 State claims and 20,933 Federal claims.

AMAX Gold continues to develop its Fort Knox gold mine near Fairbanks, which has the potential to become one of the five largest gold mines in the United States; production is expected by 1995 . Other active gold prospects include properties on Ester Dome near Fairbanks, the Valdez Creek Mine north of Anchorage, Nome-area gold veins, and the Alaska-Juneau and Kensington Mines in the Juneau gold belt of southeastern Alaska. Exploration for nongold metals includes the Taurus copper property near Tok, lode platinum near Goodnews Bay, and the Pebble Beach copper deposit near Lake Iliamna.

The Alaska Mineral Resource Assessment Program (AMRAP) continues to be the focus of USGS mapping and mineral assessment in Alaska. In 1992, USGS scientists released numerous reports on geologic mapping, mineral-resource assessment, and specialized geologic studies of Alaska lands; conducted field studies, research, and report writing for mineral assessments of twenty-five 1:250,000-scale quadrangles; and performed specialized geologic studies on a detailed scale for 27 projects around the State. The first geologic map of the Holy Cross quadrangle was compiled, and the "Metamorphic History of Alaska" was published.

USGS researchers also performed site-specific studies on precious-metal deposits and strategic and critical mineral deposits. The copper-lead-zinc deposits of Prince William Sound were catalogued and classified. Cooperative programs with Russian scientific agencies, the State of Alaska, and the Canadian Geological Survey continued in 1992; metallogenesis of the Circum-North Pacific Terrane was discussed at workshops and scientific meetings throughout the year, and ophiolite maps of Alaska were published. Previously collected field data from the TransAlaska Crustal Transect Program were compiled and analyzed, and new data were collected in the northern Brooks Range and southern North Slope. Field work for the cooperative USGS-USBM-BLM mineral resource study of the Colville mining district in the southern NPRA uncovered several new mineral occurrences, including seven barite deposits, which increase by 50 percent the Nation's known reserves of that mineral.

In 1992, the USBM studied submarine tailings disposal, developed capital and operating-cost escalation factors for Alaskan mineral deposits, and researched costs for the design and construction of mine and mill unit processes. Ongoing USBM studies included the impact of the permitting process on mine development, the impact of proposed Federal solid-waste regulations on mineral development in Alaska, the economic impacts of land planning on mining in the Tongass National Forest, and the impact of "ecosystem management" concepts on mineral development. The Mining Claim Information System (MCIS) was updated. The USBM continued mining-district studies, site-specific mineral investigations, abandoned-mine land activities, forest planning, and mining research.

A total of 24,617 Federal mining claims were filed with the BLM in Alaska during the 1992 assessment year. Two mineral patents covering 14 claims were issued. Geologists and field support personnel from the BLM assisted the USBM and USGS in the Colville mining district study. The FWS reviewed 21 permits for mining-related activities off wildlife refuges.

The NPS continued to process plans of operations for mining and mining access in national park units. One operation was approved, and three rejected; environmental and engineering analyses were begun on an additional three plans. Permits for AMRAP projects in national parks were issued to the MMS, USBM, and USGS. Claimvalidity examinations were completed on 55 claims, and 17 new historic mining sites were located. Reclamation research continued in the Kantishna area of Denali NP\&P.

The U.S. Forest Service (USFS) is revising the Tongass Land Management Plan to apply a mineralsmanagement prescription encouraging minerals development on lands having a high potential for mineral 
resources. The Record of Decision for the final environmental impact statement on the Kensington project was issued by the Chatham Area Forest Supervisor. The USFS also conducted mineral-validity examinations and inventories of environmental and safety hazards on abandoned and inactive mining claims in the Tongass and Chugach National Forests.

\section{INDUSTRIAL MINERALS}

The production of sand, gravel, and building stone, valued at $\$ 65$ million, has remained static for the last 6 years; in 1992, 13.2 million metric tons of sand and gravel and 2.6 million metric tons of building stone were quarried. The value of jade and soapstone increased 150 percent from 1991, to $\$ 30,000$ in 1992.

The FWS allowed gravel extraction in the Izembek NWR and considered a gravel sale in the Alaska Maritime NWR. The USFS continued to sell sand, gravel, and quarried stone for use in the construction of timber-sale roads, breakwaters, and airports. The BLM made a number of mineral-materials sales.

\section{INTRODUCTION}

Section 1011 of the Alaska National Interest Lands Conservation Act (ANILCA) of 1980 requires that "On or before October 1, 1982, and annually thereafter, the President shall transmit to Congress all pertinent public information relating to minerals in Alaska gathered by the United States Geological Survey, Bureau of Mines, and any other Federal agency." The USGS subsequently was delegated as the lead agency in responding to this requirement. This circular is the twelfth in its series, synthesizing information made public in 1992. The report focuses on energy resources (oil, gas, coal, peat, uranium, and geothermal) and nonfuel-mineral resources (metallic and industrial minerals).

The USGS and the USBM are the principal Federal agencies that generate information about onshore mineral resources in Alaska; the MMS is the prime agency reporting on resource activities in Alaska's coastal waters. Their data, analyses, and reports are used by other agencies for resolving questions on land use, access, environmental impacts, and mining claim evaluation.

As used herein, the term "public information" includes results of Federal projects as published in Government reports and professional and trade journals; oral presentations by representatives of Federal and State agencies and industry at symposia, conferences, and other public forums; and proceedings volumes, press releases, and newspaper articles. Many of the cited references are listed at the end of this report; however, most of the papers cata- logued in the text are identified as being listed in appendix 1 , which inventories mineral reports published or released in 1992 or early 1993. Data from the State's annual report on Alaska's mineral industry are cited in parts of this circular.

The next section describes the current mineral programs of land-management and other Federal agencies in Alaska. The roles of these agencies as they relate to minerals are discussed in appendix 2 . The distribution of lands under Federal management is shown in figure 1.

\section{MINERAL PROGRAMS}

\section{DEPARTMENT OF THE INTERIOR}

\section{U.S. GEOLOGICAL SURVEY}

As directed by Section 1010 of ANILCA, the Secretary of the Interior is required to assess "the oil, gas, and other mineral potential on all public lands in the State of Alaska in order to expand the data base with respect to the mineral potential of such lands." The AMRAP is one of the major responses of the USGS to this legislation. The goal of this program is a systematic investigation of the State's mineral resources through four progressively more detailed levels of study. Geologic studies at level I cover the whole State, and at level II cover large areas. Studies at level III draw on many geologic disciplines to produce resource assessments at scales of 1:250,000 and 1:125,000 (fig. 2). Level IV research focuses on detailed studies of specific mining districts, mineral deposits, or topics relating to the genesis of mineral deposits. In 1992, level III studies were under way in 25 quadrangles, and 27 level IV studies were in progress.

USGS AMRAP publications are a key source of information about Alaska's geology and resource potential. AMRAP studies are essential for the determination of the distribution and potential of national mineral and energy endowments, for the formulation of public policy affecting resource and land management, and for the improvement of resource-assessment technology in minimizing potential impacts from development. These studies, which develop the concepts, models, and techniques needed to identify new mineral deposits, are vital to the minerals-exploration industry.

The USGS performs its resource-assessment work in Alaska through several programs in addition to AMRAP. Among the programs active in 1992 were (1) studies of mineral resources on public lands; (2) the Development of Assessment Techniques Program, which has a goal of improving the ability to identify and evaluate mineral resources; (3) the Strategic and Critical Minerals Program, which identifies the potential of these resources to meet national military and economic needs; and (4) the Oil and 


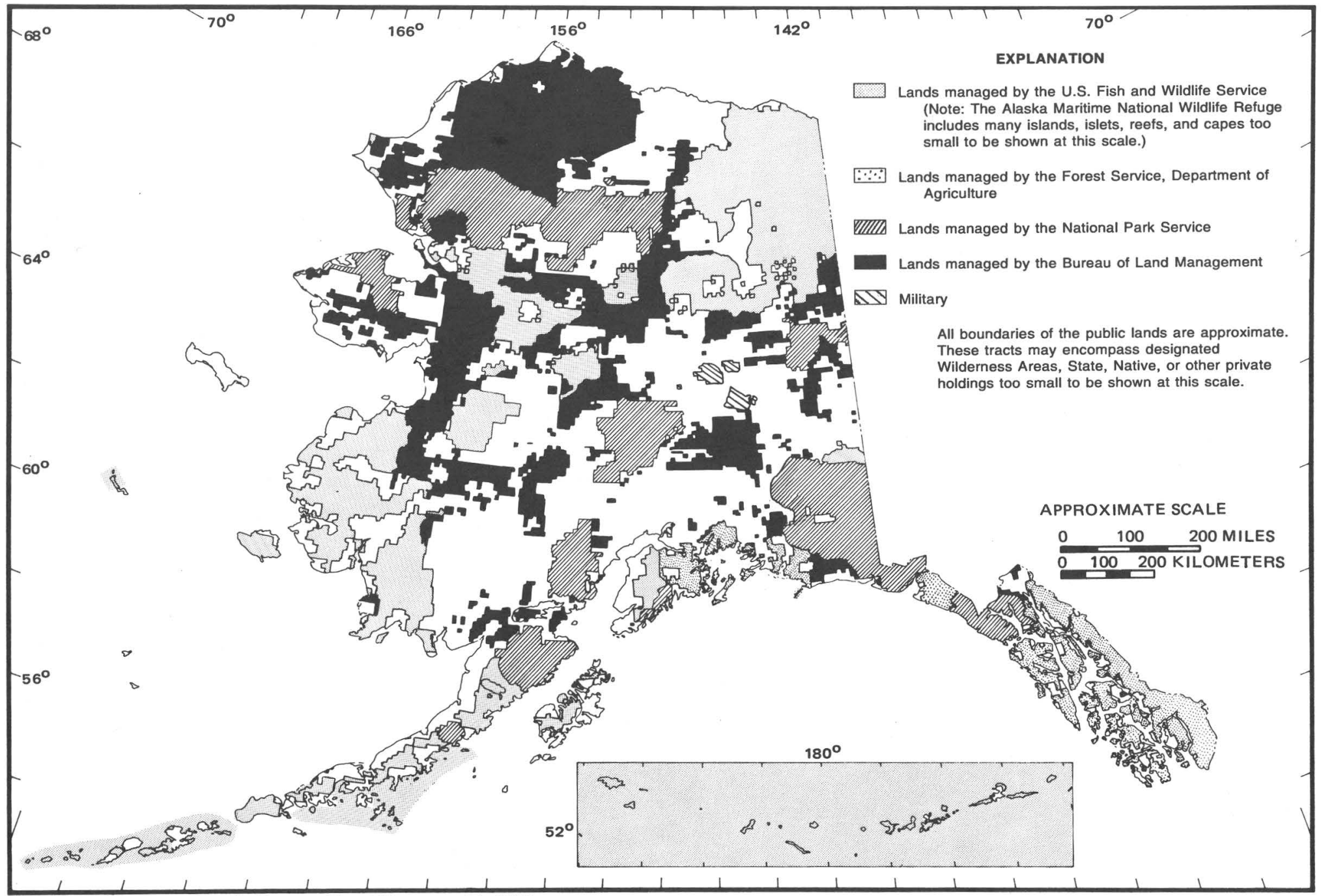

Base from maps prepared by the Bureau of Land Management in 1987.

Figure 1. Federal land ownership in Alaska (boundaries as of June 1987). 
Gas Investigations Program, which focuses on studies of petroleum-forming processes and potential source regions in order to produce reliable estimates of undiscovered petroleum resources. The mineral-related aspects of many of these programs are more fully described in later sections of this report.

Other USGS programs that are not mineral specific include (1) the Earthquake Hazards Reduction Program, which seeks to mitigate earthquake losses through providing data and evaluations for land-use planning, engineering, and emergency preparations; (2) the Volcano Hazards Program, which includes studies on the assessment, reduction, and prediction of volcanic hazards and helps fund the Alaska Volcano Observatory; (3) the Deep Continental Studies Program, which investigates the geology and geophysics of the volcanic eruption of 1912, and the resulting vent and Novarupta dome, in Katmai National Park; and (4) the Geologic Framework Program, involving both general and specialized research on the regional geology of Alaska. In addition, the Trans-Alaska Crustal Transect

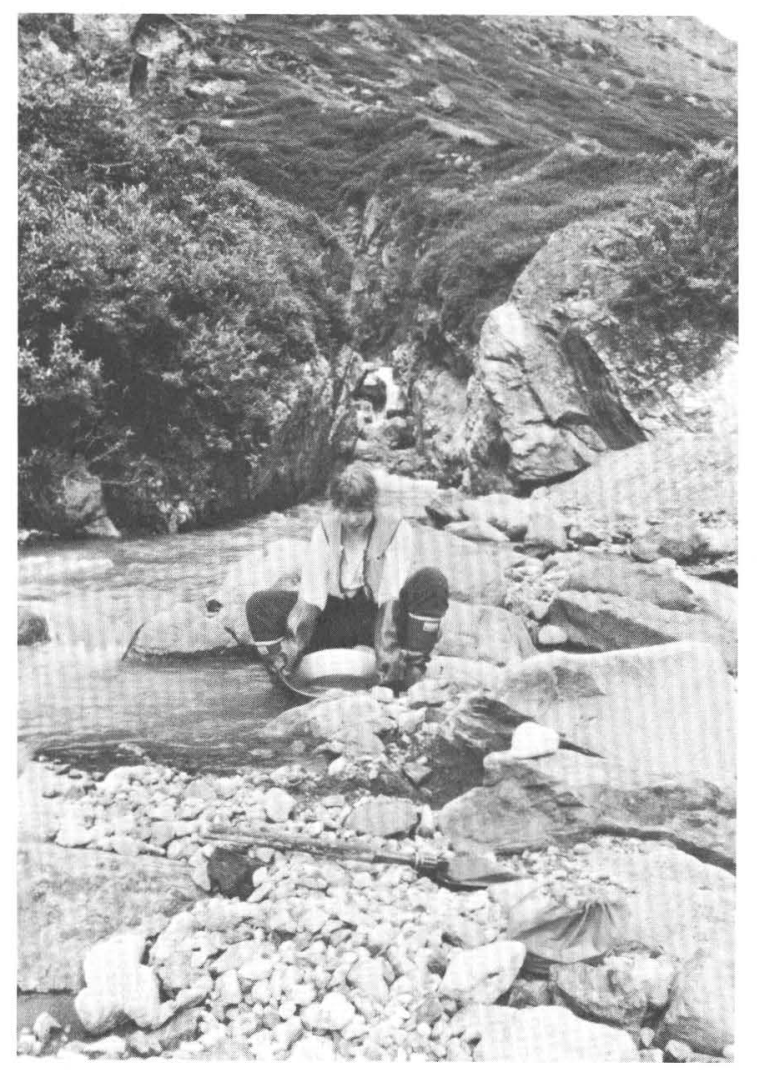

Figure 2. USGS scientist collects pan-concentrate sample for geochemical analysis as part of level III AMRAP studies in the Lime Hills quadrangle. The geochemical data will be incorporated with geologic and geophysical data to produce a mineral-resource assessment of the area. Photograph by S. Rose.
(TACT) program is a multidisciplinary approach to study the Earth's crust along a corridor from the Pacific Ocean to the Arctic Ocean. This program is coordinated with the Trans-Alaska Lithosphere Investigation, which utilizes earth scientists from the ADGGS, the University of Alaska, other universities, and private industry.

Information for mineral deposits and occurrences in the United States and worldwide is available through computerized files of the USGS Mineral Resources Data System (MRDS). In Alaska, there are presently 4,155 records in one-hundred 1:250,000-scale quadrangles throughout the state. Data in these files include up to 200 entries related to record identification, location, geology, deposit type, exploration and development, mine workings, commodity, production, reserves, resources, and references (Leonard and Huber, 1987). Geologic and deposit information from the Alaska MRDS files can be used to complement economically oriented data from the Minerals Availability System (MAS) computerized files of the USBM, discussed in the next section. Further MRDS information can be obtained from Ray Arndt, MRDS Project Chief, U.S. Geological Survey, 920 National Center, Reston, VA 22092-0001.

\section{U.S. BUREAU OF MINES}

During 1992, the Alaska Field Operations Center (AFOC) and various research centers of the USBM were active in the programs listed below; see appendix 2 for further information on the scope and nature of these programs.

Minerals availability.-The two computerized components of the minerals availability program are the MAS and the Mineral Industry Location System (MILS) data bases. MAS contains information on reserve estimates, mineral extraction and beneficiation methodologies, environmental constraints on mining, and cost analyses for selected major mineral deposits. MILS lists basic information on the identification and location of known mineral deposits.

Policy analysis.-The policy analysis program compiles analyses of mineral data with respect to local and national needs. Technical, institutional, political, social, and economic criteria are used to identify mineral issues.

State mineral activities.-A USBM Alaskan State Mineral Officer compiles and analyzes mineral data to report on activities and trends within Alaska's mining industry.

Mineral land assessment.-The USBM's major emphasis in Alaska is the development of areal and commodity-oriented mineral assessments. An integral part of this program focuses on evaluations of mining districts in the State, including assessments of the type, quantity, distribution, reserves, and beneficiation characteristics of specific mineral deposits (fig. 3). The program also emphasizes site-specific investigations of deposits that contain strategic and critical minerals and advanced materials. 
USBM scientists locate, map, and estimate the size and grade of mineral deposits; they also collect samples for ore characterization and beneficiation research.

Minerals research.-Minerals research in Alaska includes efforts to improve mining technology, mineral extraction, and environmental aspects of the mineral industry, while considering Alaska's distinctive climate and geologic conditions. Research is administered by one or more of nine USBM research centers in the lower 48 States or by Washington headquarters, as is the case with the cooperative programs with universities such as the Mineral Institutes. Although partially funded by the USBM, the Mineral Institutes utilize university staff and facilities to conduct their work. Researchers from the University of Alaska at Fairbanks Mineral Institute were active in Alaska in 1992.

Much of the USBM's work involves highly speculative, long-range research that promises major technological improvements. Corporate industry often chooses not to conduct such research; the Nation, however, cannot afford to do without it. A primary goal of this research mission is the communication of USBM research results to industry, government, and the general public.

\section{MINERALS MANAGEMENT SERVICE}

The primary mission of the MMS in Alaska is the management of mineral resource exploration and development on Federal OCS lands. Management efforts are largely focused on leasing offshore areas for oil and gas exploration and development; the MMS also has the authority to lease OCS lands for mining of hard minerals.

Prior to an OCS lease offering, the MMS appraises the economic worth of leasable offshore lands and assesses the environmental risks associated with development of resources on or beneath these lands. Following a thorough process of public review and comment, the MMS selectively makes these lands available to interested parties through competitive OCS lease sales. The MMS regulates postlease exploration, development, and production activities to ensure that operations are conducted in a safe and environmentally acceptable manner. The MMS

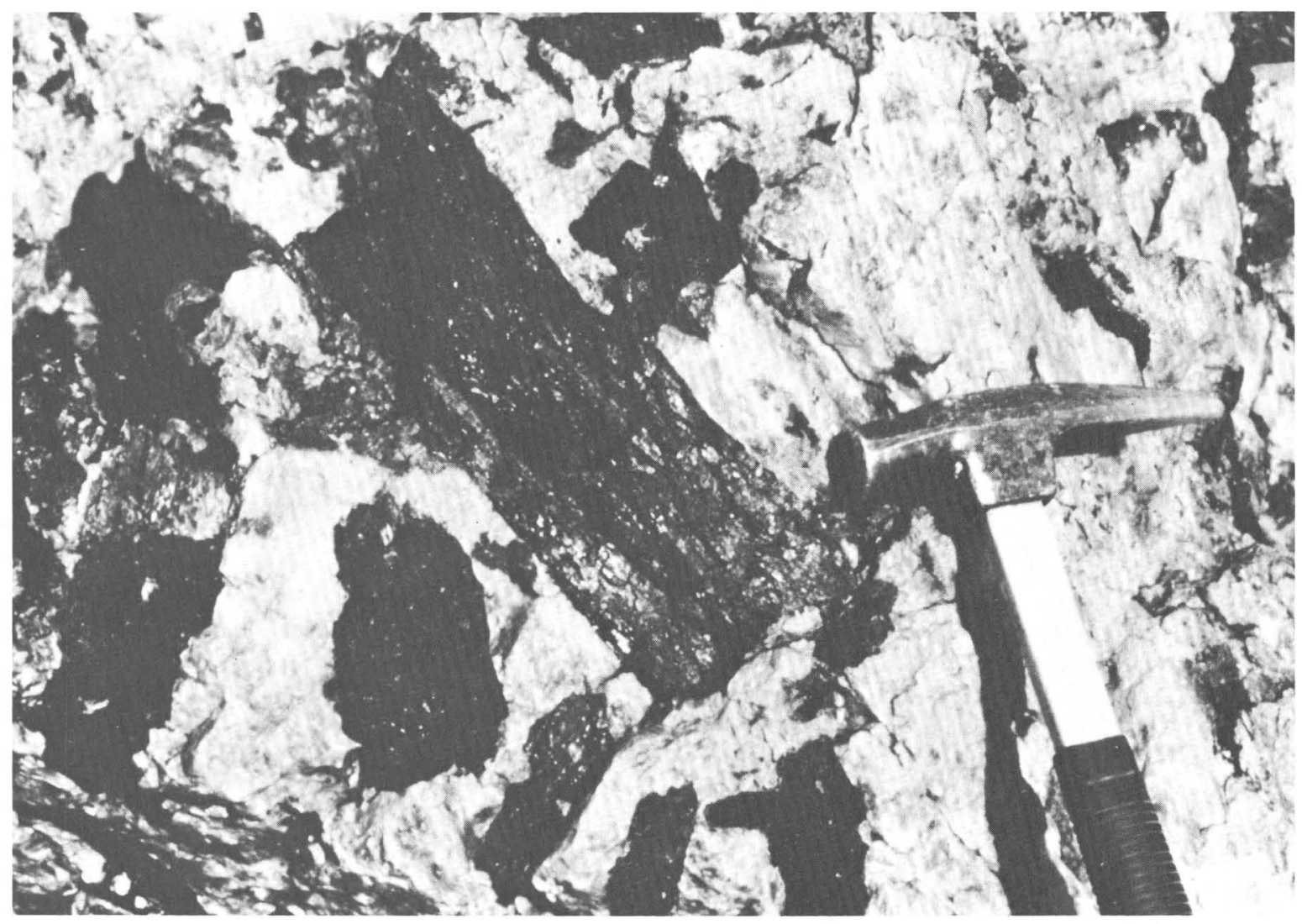

Figure 3. Pegmatite on Duke Island, southeastern Alaska, which the USBM is evaluating as a potential source of beryllium, lithium, rubidium, cesium, thallium, and niobium, as well as sheet mica, perthite, and high-purity silica. Photograph by P. Bittenbender. 
inspects operations to ensure compliance with applicable laws, regulations, and lease terms. Finally, the MMS is responsible for the collection and accounting of royalty and rental revenues generated by the leased properties. At present, no minerals are being developed or produced on the Alaska OCS.

The MMS does not oversee the onshore exploration and development of Federal mineral commodities in Alaska. It is responsible, however, for the collection of royalties, bonus payments, and lease rentals generated from onshore Federal and certain Native lands. Productive leases in the Beaver Creek and Swanson River oil and gas fields, as well as the Beluga, Cannery Loop, and Kenai gas fields, provide the bulk of this kind of revenue. Specific data on production and revenues from these fields may be obtained from the Minerals Management Service, Royalty Management, Lakewood, CO 80225.

The MMS also conducts regional studies of the geologic history and petroleum potential of Alaska's offshore basins for the National Resource Assessment, the MMSUSGS inventory of America's oil and gas resources. Results of these studies have been published as part of the MMS OCS report series. Appendix 1 lists these titles. Copies of the reports may be obtained from the MMS regional office library in Anchorage.

\section{BUREAU OF LAND MANAGEMENT}

The principal activities of the BLM related to Alaska's onshore mineral and energy resources are (1) assessment of the mineral potential of BLM planning areas (fig. 4) and, through the planning process, identification of how the minerals can best be managed; (2) development of the terms and conditions, through the planning process and environmental review in accordance with the National Environmental Policy Act (NEPA), for mineral exploration and development on BLM lands; (3) providing mineral resource and economic evaluations to determine mineral values for lease sales, land exchanges, and Federal land disposal; (4) issuance and management of Federal leases in coordination with the responsible surface-management agency; (5) administrative maintenance and adjudication of Federal mining claims, determination of the validity of claims, critical review of Federal mineral validity reports, and issuance of mineral patents; (6) regulation of mining activities on BLM lands to protect the environment; (7) regulation, permit and agreement approval, inspection of oil and gas leasehold operations, and enforcement of onshore orders for Federal leases producing oil and gas in the Cook Inlet Basin, in compliance with the BLM's National Inspection and Enforcement Strategy; (8) active participation in the State's Abandoned Well Site Closure Program for plugged and abandoned wells on Federal lands; and (9) protection of public mineral resources through an active program to identify, analyze, and study oil and gas drainage patterns.
The BLM is responsible for enforcing the environmental and technical stipulations of the Agreement and Grant of Right-of-Way for the Trans-Alaska Pipeline System (TAPS); the overall goal of this effort is to maintain a continuous supply of energy via pipeline integrity and to ensure public safety and environmental protection by minimizing environmental impacts. In addition, the BLM issues land-use authorizations and conducts mineralmaterials sales to support the operations and maintenance of TAPS, as well as preconstruction activities for the planned natural-gas pipeline and other projects. The BLM has also provided assessments of mineral-potential studies for other land-managing agencies, such as the FWS and NPS, and for input to congressional initiatives.

Administrative responsibilities for minerals require close coordination with other surface-management agencies. Generally, in the case of onshore leases, the BLM issues leases and integrates leasing with other land uses in cooperation with the surface-management agency. To assure proper surface and subsurface protections after a lease is issued, the BLM enforces the regulations of 43 Code of Federal Regulations (CFR) 3160 and the lease stipulations and permit conditions for exploration and development activities.

\section{U.S. FISH AND WILDLIFE SERVICE}

In Alaska, the FWS manages 76 million acres of national wildlife refuge lands and an additional 18 to $22 \mathrm{mil}-$ lion acres of lands within the refuge boundaries that have been selected by the State or by Native corporations but have not yet been conveyed to them. The FWS is also responsible for research and monitoring of contaminants in fish and wildlife resources; for enforcement of Federal wildlife laws on and off refuges; and for coordination and comment under the Fish and Wildlife Coordination Act, which provides for review and comment of Federal permitting and development activities in waters and wetlands. This latter function includes the investigation, review, and comment on Federal permits and environmental impact statements.

Mineral activities may be allowed under permit on national wildlife refuges provided that the activity is compatible with the purposes for which the refuge was established. Under Section 810 of the ANILCA, if an activity would significantly restrict subsistence use of Federal lands, the agency must give notice and hold hearings to determine (1) that the restriction is necessary, (2) that a minimum amount of land is affected, and (3) that reasonable steps are taken to minimize adverse impacts upon subsistence uses and resources. The locations of the 16 national wildlife refuges in Alaska are shown in figure 5.

The FWS makes recommendations to other Federal agencies for mitigating adverse impacts to fish, wildlife, and habitats from federally constructed, funded, or permit- 
ted projects. The FWS reviews U.S. Army Corps of Engineers (ACE) permit applications under Section 404 of the Clean Water Act of 1977, as amended, and under Section 10 of the Rivers and Harbors Act of 1899, as amended. These permit requirements apply to both public and private lands and waters.

The FWS manages migratory birds, listed threatened and endangered species, and certain marine mammals. When an agency is considering permit applications for exploration or development activity, that agency must determine if listed species are present within the area of activity. When a listed species is present, and it is determined that the proposed activity may adversely affect that species, the agency must consult with the FWS in accordance with the Endangered Species Act of 1973, as amended.

The FWS manages three marine mammals species in Alaska: polar bear, sea otter, and Pacific walrus. Section 101(a)(5) of the Marine Mammal Protection Act of 1972, as amended, authorizes the Secretary of the Interior to allow, via a permit, a U.S. citizen, engaged in a specified activity in a specified region, the incidental, but not intentional, taking of small numbers of marine mammals.

\section{NATIONAL PARK SERVICE}

Under its congressionally mandated mission, the NPS manages all units of the National Park System so as "to conserve the scenery and natural and historic objects and the wild life therein and to provide for the enjoyment of the same in such manner and by such means as will leave them unimpaired for the enjoyment of future generations" (16 U.S.C. 1 et seq.). With three exceptions that exist in the conterminous 48 States, Congress has coupled this mandate with a prohibition against Federal mineral leasing in parks. Congress has also universally closed all park units to the location of new Federal mining claims under the 1872 Mining Law. As a result, the NPS does not manage minerals in the same sense as other Federal agencies. The NPS protects park resources and values from the adverse impacts associated with mineral development of valid existing rights. Valid existing rights may exist in a park either because they stem from Federal authorization predating the establishment of the park or they consist of rights under private (which includes rights held by Native corporations) or State ownership. Examples of such rights

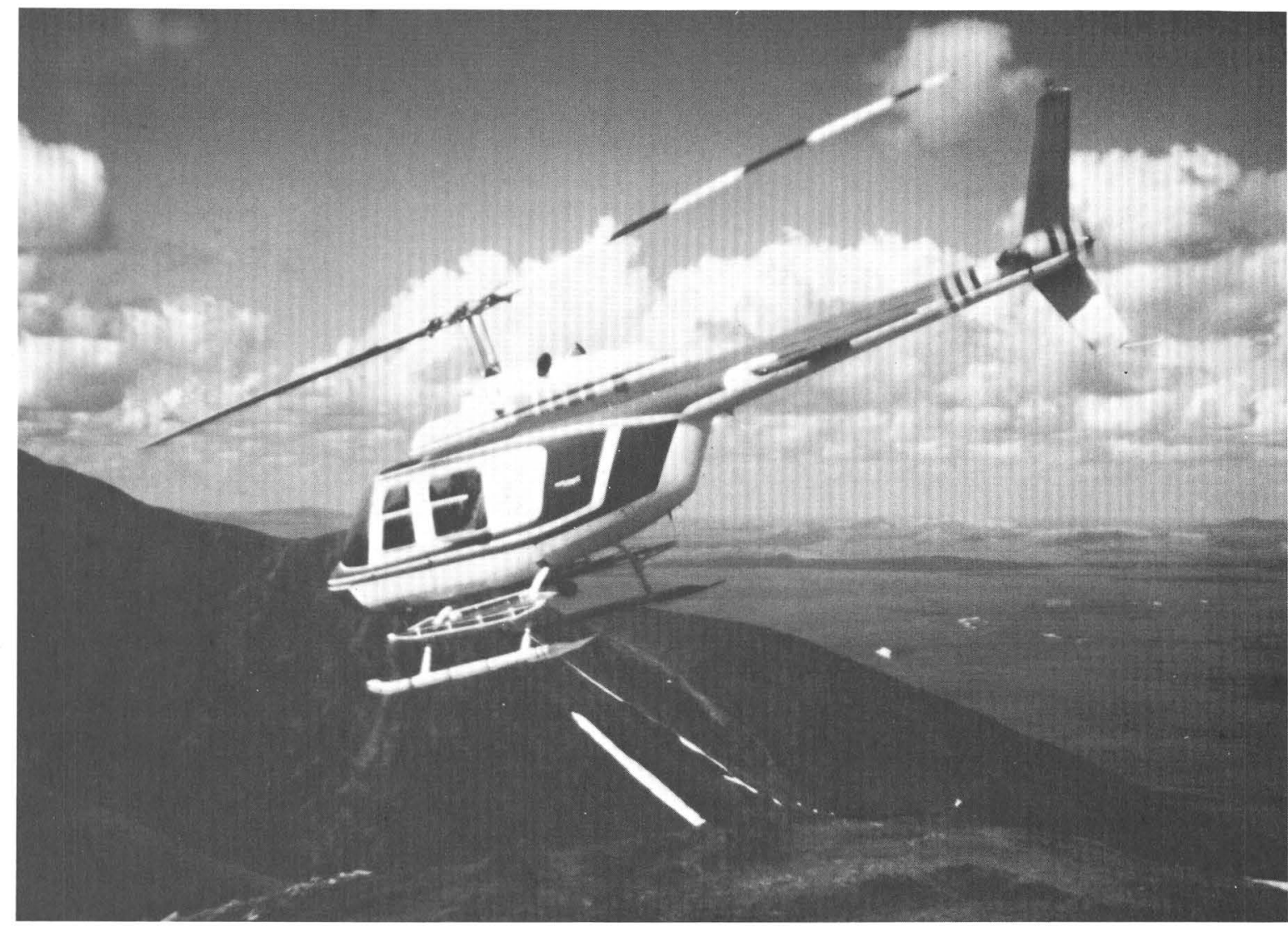

Figure 4. Helicopter used by Federal and State geologists for access to remote field sites in the Colville mining district, an area being assessed for its mineral-resource potential by USBM, USGS, and ADGGS geologists for the BLM's Arctic District Land Management Plan. Photograph by J. Schmidt. 


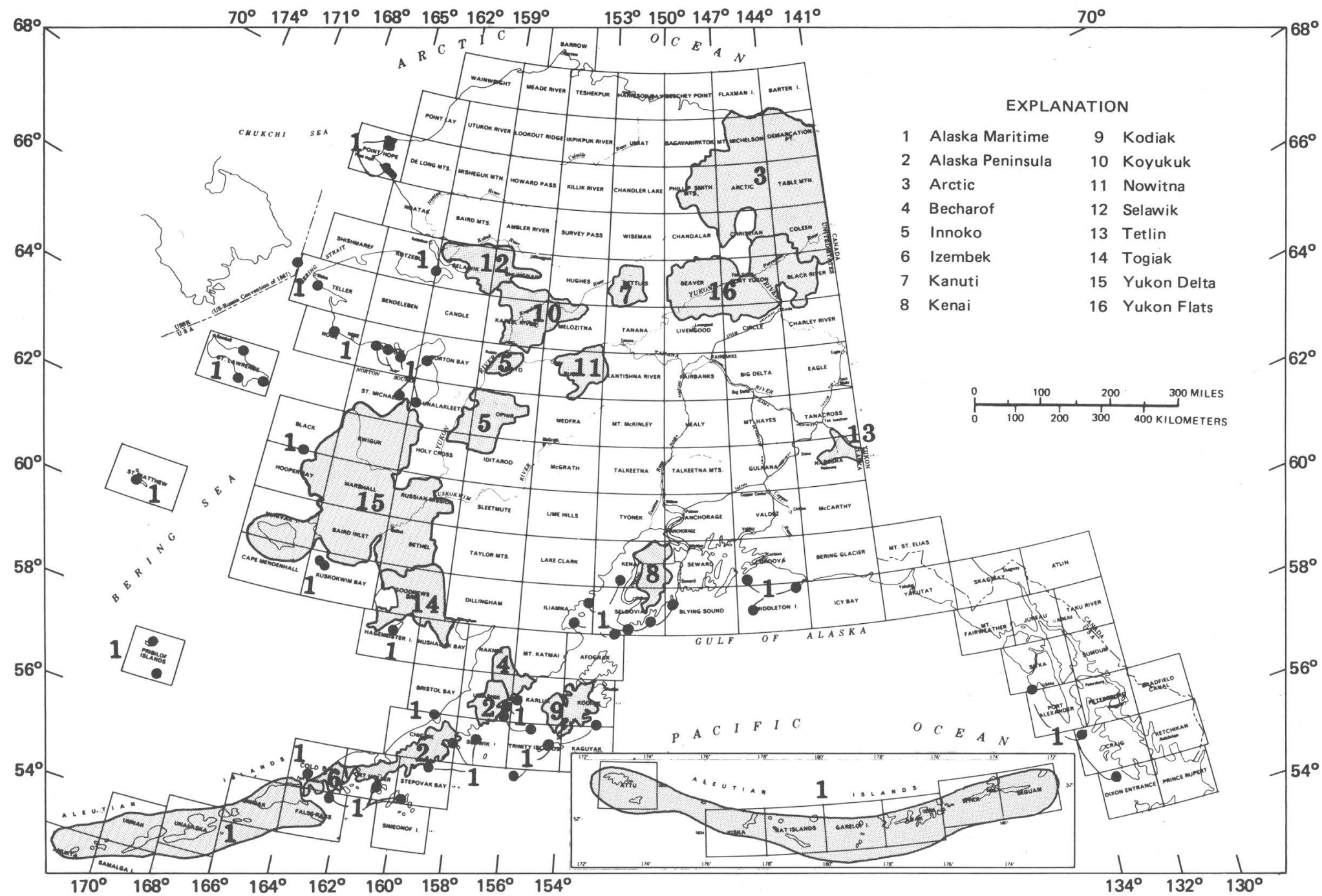

Figure 5. National wildlife refuges in Alaska. 1:250,000-scale quadrangles are outlined and labeled. 
include valid mining claims located under the 1872 Mining Law prior to the establishment of the park unit or nonFederal oil and gas rights. Where valid rights exist, the NPS regulates mineral development in order to minimize adverse impacts to park resources and values.

The NPS carries out a variety of minerals-management functions, such as mineral examinations to determine claim validity; the evaluation of proposed mining plans, including completeness determination, engineering analysis, impact assessment, and bonding; compliance monitoring of approved operations; mineral valuation appraisals; and mining claim acquisition and site reclamation, where appropriate. Major programs have been undertaken to survey, take aerial photographs, and map mining claims; to prepare topographic maps of mining claims (scale 1:1,200, 10 -foot contour interval); to inventory abandoned mineral lands; to perform hydrologic monitoring; to reclaim abandoned and acquired mining claims; and to conduct reclamation research. Guidelines for NPS management and regulation of mineral-related activities are discussed in appendix 2.

\section{DEPARTMENT OF AGRICULTURE}

\section{U.S. FOREST SERVICE}

Under a memorandum of understanding with the BLM, the USFS jointly administers the general mining laws on National Forest system lands in Alaska. An example of this joint responsibility is the patent issued to Kennecott Greens Creek Mining Company for mining claims at the Greens Creek Mine near Juneau. The BLM issued this patent on the basis of favorable findings in a mineral report prepared by USFS mineral examiners.

The USFS cooperates with DOI agencies, particularly the BLM, in issuing mineral leases and assuring mitigation of surface impacts of lease activities. The USFS also cooperates with State agencies and the private sector in development of energy and mineral resources on inholdings. One such inholding is the Bering River Coal Field, which is under consideration for possible development in a joint venture by Chugach Alaska and others.

In Alaska, 23 million acres of land is administered by the USFS (fig. 1), whose regional office is in Juneau. Offices for the Chugach National Forest are located in Anchorage, Girdwood, Seward, and Cordova; Tongass National Forest offices are in Sitka, Ketchikan, and Petersburg.

\section{DEPARTMENT OF ENERGY}

In Alaska, the DOE is focusing its efforts on petroleum and coal resources. The DOE in Alaska administers congressional mandates relating to energy, monitors grants, and oversees contracts for energy-resource studies. DOE funding helps support USGS resource-assessment studies and research by the University of Alaska.

To develop a better understanding of both conventional and unconventional petroleum resources and to provide fundamental information to accelerate utilization of these resources, the DOE emphasizes resource and technological investigations that continue to expand the body of essential and basic scientific knowledge concerning conventional and heavy petroleums, shale oil, tar sands, and gas hydrates. Gas hydrates are a specific target of DOE research in Alaska.

The DOE is working to evaluate Alaskan coal in terms of its contribution to total national resources. Coal research currently centers on utilization methods suitable to Alaskan coals and conditions.

The DOE closed its regional office in Anchorage in 1985. Requests for information about DOE Alaskan activities should be addressed to the office listed below.

\section{CONTACTS FOR FURTHER INFORMATION}

\section{DEPARTMENT OF THE INTERIOR}

Bureau of Land Management

Edward F. Spang, State Director

Federal Building

222 West Seventh Avenue, No. 13

Anchorage, AK 99513-7599

U.S. Fish and Wildlife Service

Walter O. Stieglitz, Regional Director

1011 East Tudor Road

Anchorage, AK 99503-6199

Minerals Management Service

Alan D. Powers, Regional Director

Alaska OCS Region

University Plaza Building, Room 603

949 East 36th Avenue

Anchorage, AK 99508-4302

National Park Service

Jack Morehead, Regional Director

Alaska Regional Office

2525 Gambell Street, Room 107

Anchorage, AK 99503-2892

U.S. Bureau of Mines

Martin D. Conyac, Acting Chief

Alaska Field Operations Center

3301 C Street, Suite 525

Anchorage, AK 99503

U.S. Geological Survey

L. David Carter, Chief

Branch of Alaskan Geology

4200 University Drive

Anchorage, AK 99508-4667 


\section{DEPARTMENT OF AGRICULTURE}

\author{
U.S. Forest Service \\ Michael Barton, Regional Forester \\ Alaska Region \\ P.O. Box 21628 \\ Juneau, AK 99802
}

\section{DEPARTMENT OF ENERGY}

Hydrocarbon resources

Harold Shoemaker

Morgantown Energy Technology Center

P.O. Box 880, 3610 Collins Ferry Road

Morgantown, WV 26507

\section{ENERGY RESOURCES}

\section{OIL AND GAS RESOURCES}

\section{OVERVIEW OF PRODUCTION AND PRICES}

Oil and gas remained the most valuable commodities produced in Alaska in 1992. Alaska's two oil-producing areas, the Arctic North Slope and the Cook Inlet, provided 627.3 million barrels ( 1 barrel $=0.16$ cubic meters) of oil, 26.9 million barrels of natural-gas liquids, 5.65 billion cubic meters of dry natural gas, and 69.11 billion cubic meters of casinghead gas (Alaska Oil and Gas Conservation Commission Bulletin, February, 1993); 61.7 billion cubic meters of total gas production was reinjected for enhanced oil recovery. Oil production decreased 3.8 percent from 1991 levels; dry natural gas production increased slightly. Daily oil production averaged 1.7 million barrels per day (bbl/d), 144,954 bbl/d less than in 1991 and well below peak production of 2.02 million bbl/d in 1988 . North Slope fields produce about 98 percent of Alaska's oil.

Alaska North Slope crude oil price-per-barrel was at its low of $\$ 14.84$ (West Coast) at the beginning of the year, rising steadily to peak at $\$ 20.20$ in July, and declining to $\$ 17.44$ at year's end (table 1). The average 1992 price was $\$ 17.32$ per barrel (West Coast), 3.6 percent below the 1991 average of $\$ 17.96$. Alaska's treasury is especially vulnerable to crude oil prices because 88 percent of its current income is derived from royalties and taxes paid on State-owned oil and gas leases (Anchorage Daily News, April 14, 1992). Each $\$ 1$ change in the price of crude oil translates to approximately $\$ 150$ million gained or lost in State revenues.

\section{EXPLORATION}

PERMITS ISSUED

The Alaska Oil and Gas Conservation Commission approved 153 permits in 1992, for 125 development wells,
Table 1. Fluctuation in price of Alaska North Slope crude oil

[Data from Alaska Report; BP Exploration's Alaska North Slope contract crude oil price represents 95 percent of production. Contract price is based on average of spot market price for Alaska North Slope crude for prior month; price is set at beginning of each month (Alaska Report, May 11, 1988). WC, delivered to West Coast; GC, delivered to Gulf of Mexico]

\begin{tabular}{lrr}
\hline & \multicolumn{2}{c}{ Cost per barrel } \\
\cline { 2 - 3 } Date & WC & GC \\
\hline $12 / 1 / 91$ & $\$ 17.56$ & $\$ 19.16$ \\
$1 / 8 / 92$ & 14.84 & 16.47 \\
$2 / 5 / 92$ & 14.92 & 15.74 \\
$3 / 4 / 92$ & 15.26 & 16.17 \\
$4 / 8 / 92$ & 15.49 & 16.29 \\
$5 / 6 / 92$ & 16.95 & 17.77 \\
$6 / 3 / 92$ & 18.06 & 18.62 \\
$7 / 8 / 92$ & 20.20 & 20.56 \\
$8 / 5 / 92$ & 19.38 & 19.65 \\
$9 / 2 / 92$ & 18.00 & 18.82 \\
$10 / 7 / 92$ & 18.50 & 19.31 \\
$11 / 4 / 92$ & 18.80 & 19.42 \\
$12 / 2 / 92$ & 17.44 & 18.26 \\
$1 / 6 / 93$ & 16.33 & 17.19 \\
1992 average price $\ldots . . . . . . . . . . . . . . . . . . . . . . . . . . ~$ & $\$ 17.32$ & \\
\hline
\end{tabular}

12 exploratory wells, and 16 service wells. This is only a slight decrease from the 157 permits issued in 1991. Most of the approved wells were sited on the North Slope; only 3 exploratory wells and 8 development wells were planned for Cook Inlet.

\section{DRILLING ACTIVITY}

Sixteen exploratory wells were drilled in 1992, three more than the previous year: 10 wells on the North Slope, 2 in the Beaufort Sea, and 4 in the Cook Inlet region (fig. 6; table 2). Most wells were plugged and abandoned. Discoveries were announced for Cook Inlet, the North Slope, and the Beaufort Sea.

Cook Inlet.-ARCO Alaska and Phillips Petroleum each drilled a stepout well from their 1991 oil and gas discovery at the Sunfish No. 1 well, which flowed 1,100 barrels of oil and 28,317 cubic meters of gas per day. ARCO's North Foreland State No. 1 well confirmed the Sunfish discovery and revealed an oil field large enough for commercial development (Fairbanks Daily NewsMiner, January 29, 1993). Phillips spudded their Sunfish No. 2 well in late 1992 to further delineate the field. Production from the field is planned for 1996. Possible oil reserves of 750 million barrels make Sunfish the largest oil field in Cook Inlet and the fourth largest in the State, after Prudhoe Bay, Kuparuk River, and Kuvlum (Alaska Journal of Commerce, April 26, 1993). The 
Table 2. Alaska exploratory oil wells drilled in 1992

[See fig. 3 for locations. Locations for onshore and State offshore wells given in section-township-range; SM, Seward Meridian; UM, Umiat Meridian. Locations for Federal offshore wells given by latitude and longitude. ARCO-AK, ARCO Alaska; P\&A, plugged and abandoned]

\begin{tabular}{|c|c|c|c|c|c|c|c|}
\hline $\begin{array}{c}\text { Well } \\
\text { No }\end{array}$ & Company & Well name & API No. & Location & $\begin{array}{c}\text { Total } \\
\text { depth } \\
\text { (meters) }\end{array}$ & $\begin{array}{c}\text { Date } \\
\text { completed } \\
(1992)\end{array}$ & Remarks \\
\hline
\end{tabular}

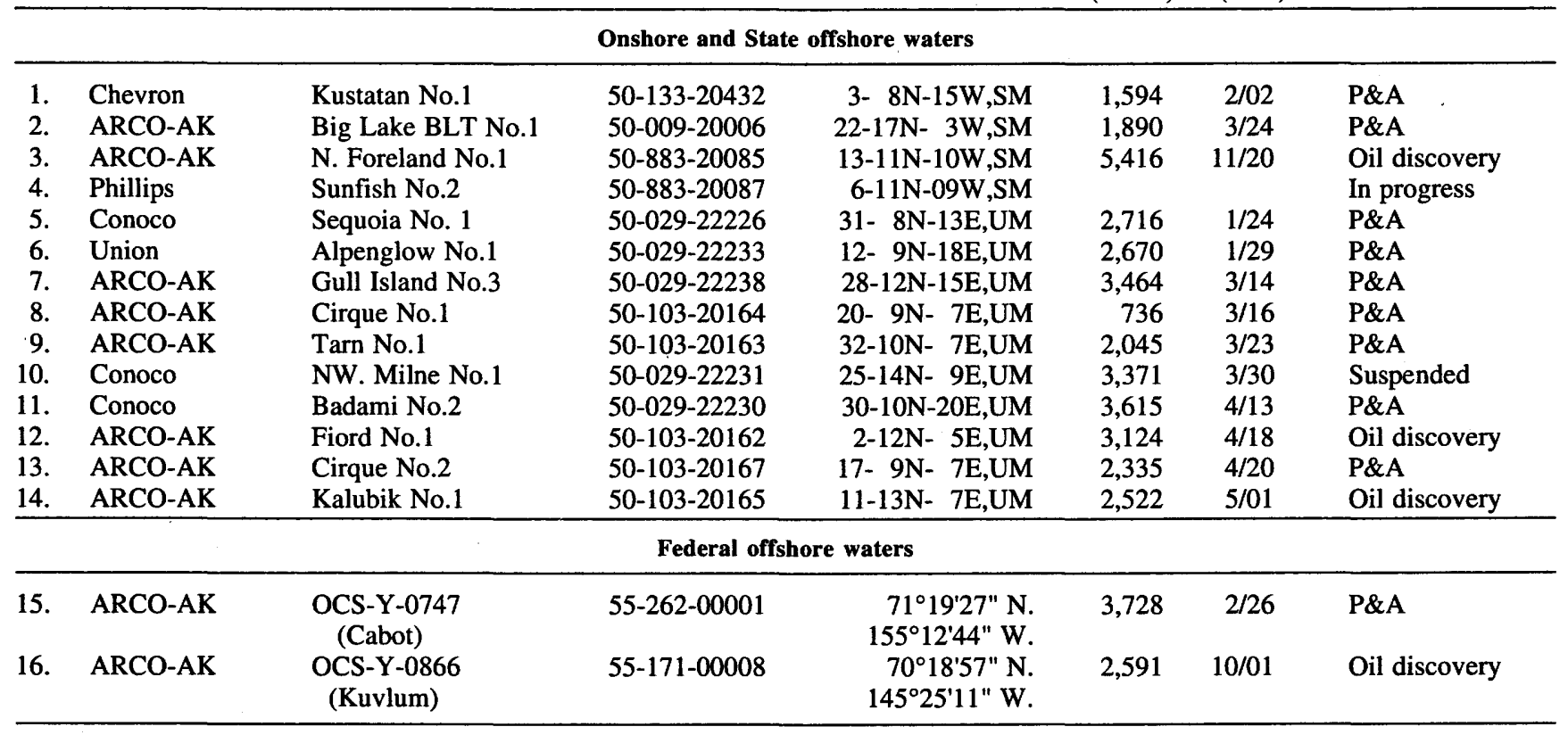

Sunfish discovery and Stewart Petroleum's West McArthur River discovery in 1991 are the first Cook Inlet oil discoveries since 1965.

On the east side of Cook Inlet, about 24 kilometers south of the Swanson River field, Cook Inlet Region Incorporated (CIRI) Production Company, an Anchorage-based Native corporation, announced a successful delineation well, the West Fork 2-21, in the West Fork gas field.

North Slope.-ARCO Alaska announced two oil and gas discoveries in the Kuukpik Unit of the North Slope's Colville River Delta region (Alaska Report, December 22, 1992), west of the Kuparuk River field. The land-based Fiord No. 1 well flowed an average $1,065 \mathrm{bbl} / \mathrm{d}$, with a gas:oil ratio of 14 cubic meters per barrel. Approximately 23 kilometers to the northeast, the Kalubik No. 1 well flowed an average $1,200 \mathrm{bbl} / \mathrm{d}$, with a gas:oil ratio of 12.7 cubic meters per barrel; this well was sited on an ice island 3.2 kilometers offshore. ARCO plans to drill three more exploratory wells in the same region in early 1993.

The State approved two new exploratory units on the North Slope. The Thetis Island unit is located in the Beaufort Sea northwest of the Kuparuk River unit; Exxon Corporation plans to drill a wildcat well on Thetis Island in early 1993 to investigate potential oil reserves of 258 million barrels. The Jones Island unit is located offshore from Milne Point, 32 kilometers east of the Thetis Island unit. ARCO, the unit operator, plans to drill an exploratory well in the Jones Island unit in the first quarter of 1993.
Arctic NWR.-A provision to open the Arctic NWR coastal plain to oil drilling was removed from the Energy Policy Act of 1992, Public Law 102-486, 106 Statute 277 (October 24, 1992).

Beaufort Sea.-ARCO announced an oil and gas discovery at its Kuvlum prospect in Camden Bay in the eastern Beaufort Sea, 26 kilometers offshore from the northwestern corner of the Arctic NWR and about 97 kilometers east of Prudhoe Bay. The discovery OCS-Y-0866 well tested 3,400 barrels of oil and 56,634 cubic meters of gas per day; average gas:oil ratio was 17 cubic meters per barrel. Total depth of the well was 2,591 meters. Cost of the test well was set at $\$ 45$ million. Two follow-up wells were drilled in the summer of 1993. According to ARCO, the discovery will have to contain at least one billion barrels of recoverable oil to prove commercial; development will take 8 to 10 years. ARCO owns a 50-percent working interest in the well; partners in the discovery include Union Texas Petroleum, Phillips Petroleum, Total Minatome, Murphy Oil USA, and Mobil Exploration and Production U.S. (Rintoul, 1993).

\section{GEOPHYSICAL SURVEYS}

State permits allowed ARCO to shoot 1,900 line-kilometers of seismic and gravity surveys in upper and lower Cook Inlet, plus 40 to 60 line-kilometers of seismic and gravity surveys in Shelikof Strait. Seismic-reflection data 




Figure 6. Locations of exploratory oil wells drilled in 1992, oil and gas fields, and possible petroleum-bearing sedimentary basins (outlined). Basins adapted from Kirschner (1988). 1:250,000-scale quadrangles are outlined and labeled. 
were also collected in Federal waters: 2,800 line-kilometers in the Lower Cook Inlet, and 30 line-kilometers on the Beaufort Sea shelf. In addition to these regional surveys, permits were also authorized for six single-well or singlepad seismic programs, including one in the Cook Inlet (Alaska Report, December 29, 1992).

\section{PRODUCTION}

During 1992, there were 1,599 producing oil wells, 112 gas wells, and 599 service wells active in Alaska (Alaska Oil and Gas Conservation Commission, February, 1993). Of these, 137 development and service wells were drilled in 1992: 12 in Cook Inlet, 3 in the Endicott field, 46 at Kuparuk River, 65 at Prudhoe Bay, 6 at Point McIntyre, 4 at Walakpa, and one elsewhere on the North Slope. Little information on these wells has been released to the public, but some data are made available through the Alaska Oil and Gas Conservation Commission's monthly bulletins and the Petroleum Information Corporation's weekly Alaska Report.

\section{NORTH SLOPE}

Prudhoe Bay.-Oil production from the Prudhoe Bay field declined 6 percent in 1992 to 470.5 million barrels. Gas is now the limiting factor on Prudhoe oil production. As the field ages, greater quantities of gas and water are produced along with the oil; these must be separated before the oil goes into the pipeline. Facilities for separating and reinjecting the gas back into the reservoir are currently operating at capacity. The present GHX-1 plant is already the largest gas-separation facility in the world, daily reinjecting about 142 million cubic meters of gas into the reservoir through 22 wells. A second gas-handling facility, GHX-2, is now under construction. The project is expected to increase production by another $100,000 \mathrm{bbl} / \mathrm{d}$ when the plant comes on line in 1995 and to allow an additional 330-450 million barrels of oil to be recovered (Alaska Report, October 23, 1991). The original estimate for recovery from the 24-billion-barrel Prudhoe Bay field was 9.4 billion barrels, but with water flooding, high-pressure fracturing, and gas reinjection, the estimates for total recovery are now about 12 billion barrels.

Shared services in the Prudhoe Bay field have been successful in reducing costs for field operators (Alaska Report, February 5, 1992). Drilling costs for development wells have been reduced from $\$ 3$ million to $\$ 2$ million per well, and the time required to drill a well has been cut in half.

Kuparuk River.-Kuparuk River, the Nation's second largest oil field, continues to set new production records. The field produced 118.5 million barrels of oil in 1992, up 4.4 percent from 113.5 million barrels in 1991. Increased production comes from the western section of the field, coupled with good performance of the enhanced-recovery projects. There are now 371 producing wells out of 700 drilled. Most wells are drilled on 0.65-square-kilometer spacing, but drilling now is underway on a tighter, 0.32square-kilometer spacing (Alaska Journal of Commerce, October 5, 1992). Originally, production from this field was expected to peak at $250,000 \mathrm{bbl} / \mathrm{d}$ with ultimate recovery of 1.2 to 1.5 billion barrels; engineers currently expect production to remain in the $300,000 \mathrm{bbl} / \mathrm{d}$ range through 1997 and to recover 1.8 to 1.9 billion barrels. Special efforts to control costs of the Kuparuk development have begun to pay off (Alaska Journal of Commerce, November $11,1992)$. This is especially significant in the Kuparuk River field, where development costs have been three times as much per barrel of developed reserves as in the Prudhoe Bay field; transportation costs are also greater due to distance from the Trans-Alaska Pipeline and the premium paid for the heavier crude oil.

Endicott.-Production from the Endicott field was 41.6 million barrels of oil in 1992.

Milne Point.-Conoco expects to almost double its recovery of oil from the Schrader Bluff pool of the Milne Point oil field by using waterflood techniques (Anchorage Times, January 23, 1992); 1992 production was 6.95 million barrels. Primary recovery was expected to recover only 12 percent of the estimated 1.2 billion barrels of inplace oil, whereas waterflooding is expected to increase recovery to 21 percent, or 250 million barrels. The Schrader Bluff pool, situated in the geologically youngest oil-producing reservoir on the North Slope, the (informal) West Sak sands, was put into production in March 1991. Currently, 11 wells produce from this pool and yield 3,500 bbl/d. Submersible pumps and special gravel filters are used to overcome the thick oil and well-clogging sand that characterize this reservoir, which is located at a depth of about 1,219 meters. This is the only North Slope field to use pumps; in all other fields, oil flows to the surface under its own pressure (Alaska Journal of Commerce, January 20,1992). Field owners are Conoco, Chevron USA, and Oxy Oil and Gas USA.

Point McIntyre.-The Point McIntyre field was discovered by ARCO in 1988 beneath the waters of Prudhoe Bay. Recoverable reserves of this field are estimated at 300 million barrels, one of the largest discoveries in the United States since Alaska's Endicott field in 1978. The field's three owners, ARCO Alaska, BP Exploration, and Exxon, reached agreement in 1992 for a $\$ 700$-million development plan (Alaska Report, May 13, 1992); ARCO will be the field's operator. Plans call for drilling as many as 13 wells in the field by early 1993 for delineation purposes, and production from one drillsite is expected to begin in the third quarter of 1993. Initial production is expected to begin at a rate of about $40,000 \mathrm{bbl} / \mathrm{d}$, increasing to more than $100,000 \mathrm{bbl} / \mathrm{d}$ at peak production in 1994 . Production facilities at the Lisburne field will be expanded to handle oil from the Point McIntyre field. Taxes and 
royalties from this field are expected to provide about $\$ 80$ million per year to the State treasury (Rintoul, 1993).

Kuukpik.-ARCO Alaska filed an application with the State on behalf of itself and 12 working-interest partners for establishment of the new Kuukpik unit in the Colville River Delta area. The proposed unit includes four wells already capable of production in paying quantities: Amerada Hess's Colville 25-13-6 No. 1, and Texaco's Colville No. 1, No. 2, and No. 3. Unit plans call for extensive seismic activities and three exploratory wells in the 1992-1996 period. The proposed unit encompasses 22 leases covering about 364 square kilometers located both onshore and offshore (Alaska Report, June 3, 1992).

Walakpa.-The Walakpa gas field was brought into production in 1992 to supply the village of Barrow in northwestern Alaska. The field was discovered in 1979 during the Federal government's exploration of the NPRA and was turned over to the North Slope Regional Corporation (NSRC) at the close of that program. The NSRC has drilled eight successful gas wells in addition to the original two wells drilled by Husky Oil NPRA. A 26-kilometerlong pipeline was completed in 1992 from the field to the village (see "Transportation" section). Although the exact size of the field has not yet been determined, the current 10 wells demonstrate that the field covers an area of at least 62 square kilometers. Engineering details of this field were published and presented at the International Conference on Arctic Margins (Glenn and Allen, 1992a, 1992b).

\section{COOK INLET}

General.-The four main gas fields in Cook Inlet are Beluga River, Kenai, McArthur River, and North Cook Inlet, with total production of 5.1 million cubic meters of dry natural gas in 1992, about 91 percent of the State's total. Producing oil fields are Beaver Creek (174,895 barrels), Granite Point (2.55 million barrels), McArthur River (7.4 million barrels), Middle Ground Shoal (2.4 million barrels), Swanson River (1.77 million barrels), and Trading Bay $(886,384$ barrels).

Granite Point.-In January, Marathon Oil temporarily shut down the Spark platform, which had been producing $350 \mathrm{bbl} / \mathrm{d}$. Marathon also shut down both its Spurr oil platform and Granite Point production facility in early May; the platform had been producing about $250 \mathrm{bbl} /$ day.

West Fork.-The Cook Inlet Region Incorporated (CIRI) Production Company completed a successful delineation gas well in the West Fork gas field in 1992 (Alaska Journal of Commerce, June 29, 1992). An undisclosed commercial amount of natural gas was recovered from the West Fork 2-21 well that was drilled to a total depth of 1,783 meters; this well is an offset from the company's successful West Fork 1-21 well that was completed in 1991. The West Fork gas field was discovered in 1960 by Halbouty Alaska Oil but was abandoned in 1986 by
Seagull Energy after producing 42.5 million cubic meters of natural gas. Total production to date is more than 93.7 million cubic meters of natural gas (Alaska Oil and Gas Conservation Commission, February 1993). Gas from this field is shipped via pipeline to the Phillips Petroleum liquefied natural gas (LNG) plant at Nikiski.

Nikiski LNG plant.-At the Phillips Petroleum's LNG plant on the Kenai Peninsula, natural gas from the Cook Inlet fields is cleaned of impurities, then cooled to $-162^{\circ} \mathrm{C}$; this process produces 99-percent-pure methane gas in liquid form. Approximately 95 cubic meters of natural gas are condensed into a single barrel of LNG. Construction for improved efficiency at the plant was begun in 1992. When work is completed in 1993, the two new cooling-tower cells added to the existing four towers will allow the plant to produce an average of $54,000 \mathrm{bbl} / \mathrm{d}$ LNG, a 26-percent increase from the current $43,000 \mathrm{bbl} / \mathrm{d}$, and to use less natural gas than it now takes to produce that much. About 907,000 metric tons of LNG from this plant, 20 percent of the state's natural gas production, is exported each year to two utility companies in Japan (Anchorage Times, April 17, 1992).

\section{LEASE SALES}

State of Alaska.-The State of Alaska held three lease sales on the North Slope during 1992; high bids totaled $\$ 12.2$ million. The White Hills 61 sale was held during January, offering 181 tracts covering 4,011 square kilometers. Total high bids were $\$ 2.43$ million for 46 tracts covering 1,054 square kilometers in the area south and west of Prudhoe Bay (Alaska Report, January 29, 1992). UNOCAL, BP Exploration, and ARCO Alaska were the most successful bidders. The Kuparuk Uplands 75 sale was held in December. High bidders paid $\$ 9.75$ million for 55 of the 90 tracts offered, covering 505 square kilometers in the Colville River Delta and an area west and southwest of the Kuparuk River oil field. ARCO Alaska was the successful bidder for over 76 percent of the tracts offered.

No bids were received at the Beaufort Sea 68 sale, held in June. The offering consisted of 36 tracts covering 621 square kilometers offshore of the barrier islands in the Point Barrow area of the NPRA, between Tangent Point and Nulavik (Alaska Report, June 3, 1992). This was the first State sale to draw no bids.

Federal Government.-No Federal lease sales for oil and gas were held in 1992. The MMS 5-year lease schedule includes six sales, the first proposed to be held in 1994.

\section{TRANSPORTATION}

Trans-Alaska Oil Pipeline.-More than 9 billion barrels of oil have been transported by the TAPS. In 1992, a daily average of 1.8 million barrels of oil was carried through the 1,290-kilometer-long, 1.2-meter-diameter pipeline. Declining production from North Slope fields may 
lead to cost-cutting efforts in order to extend the economic viability of the pipeline. As less oil flows through TAPS, less power is needed to move it along its lengthy route; therefore, one or more pumpstations could feasibly be temporarily idled or even shut down to save money. Each station employs between 24 and 48 people (Anchorage Daily News, January 7, 1992).

The operation of TAPS is monitored by the Joint Pipeline Office (JPO), where eight Federal and State agencies are co-located. During 1992, the JPO participated in 14 oil-spill response, containment, and cleanup drills. The JPO also initiated the use of a field-monitoring manual that contains 20 field-monitoring plans. Data from these plans have been entered in a computerized data base for tracking of conditions along the TAPS right-of-way.

Since 1989, corrosion-detection devices known as "smart pigs" have traveled inside the pipeline to map the integrity of its walls. In November 1992, an interagency task force published its report, "Corrosion Protection Monitoring of the Trans-Alaska Pipeline System, Final Report" (U.S. Department of Transportation-Office of Pipeline Safety, Bureau of Land Management, and State of Alaska, 1992). Although the report identified concerns regarding adequate data as required in 40 CFR 195, it was clear that the data produced by the "smart pigs" were sufficient to ensure continued pipeline integrity, public safety, and environmental protection.

In the Brooks Range, 13.7 kilometers of TAPS was rerouted; construction was finished on time and under budget (Newcomer and McDevitt, 1992).

Walakpa Pipeline.--In northwestern Alaska, the city of Barrow is totally dependent on natural gas for heating and power generation. In 1992, the North Slope Borough constructed a \$9.5-million, 26-kilometer-long pipeline and gathering system to carry natural gas from the Walakpa gas field to Barrow (Anchorage Times, January 22, 1992). The Walakpa gas will relegate supplies from the South and East Barrow gas fields to backup status. The Walakpa field was discovered in 1979 during the Federal Government's exploration program in the NPRA. The Walakpa No. 1 discovery well and Walakpa No. 2 confirmation well were drilled by Husky Oil. The North Slope Borough has drilled an additional eight wells in the field; all have been classified as gas producers.

Trans-Alaska Gas System.-Demand for LNG in Japan, Korea, and Taiwan, currently about 34 million metric tons per year, is expected to double by the year 2010; current and replacement supplies are expected to provide only about 80 percent of demand, or 53.5 million metric tons yearly. The Yukon Pacific Corporation has proposed building the Trans-Alaska Gas System (TAGS), a \$14billion, 1,290-kilometer-long natural gas pipeline to bring North Slope gas to a plant in Valdez capable of producing some 12.7 million metric tons LNG per year; the TAGS pipeline would parallel the TAPS pipeline. However, most
North Slope gas is reinjected for enhanced-recovery projects, and operators fear that diverting gas withdrawals at this time will result in a significant reduction in longterm oil recovery (Alaska Journal of Commerce, October 5,1992 ). This, in turn, would shorten the life of the TAPS oil pipeline. Other concerns include TAGS construction finances, future domestic and foreign LNG demand, competition from other natural gas sources, and competition from alternate energy, such as nuclear power. In addition, commitments to buy the 12.7 million metric tons per year required to make TAGS economic have not been obtained (Anchorage Daily News, September 11, 1992).

Alaska Natural Gas Transportation System.-The Alaska Natural Gas Transportation System (ANGTS) is a proposed natural-gas pipeline that would carry North Slope gas through Canada to the conterminous United States. The ANGTS Federal Inspector has suggested to the White House that the venture be abandoned and the office shut down. The office of the ANGTS Federal Inspector has a staff of three, an annual budget of $\$ 338,000$, and has been in existence since the 1976 Alaska Natural Gas Transportation Act was enacted during the Carter administration.

\section{ACTIVITY BY FEDERAL AGENCIES}

\section{MINERALS MANAGEMENT SERVICE}

\section{LEASING AND EXPLORATION ACTIVITY}

Since 1976, the DOI has held 17 oil and gas lease sales on the Alaskan OCS (fig. 7, table 3), offering over 546,330 square kilometers. The DOI has leased 34,400 square kilometers ( 1,562 leases) and has received $\$ 6.5$ billion in high bonus bids (table 4). A total of 1,028 leases have been relinquished or allowed to expire, leaving 534 leases still held by oil companies. No lease sales for oil and gas were held on the Alaskan OCS in 1992.

Fourteen deep stratigraphic test (DST) wells and 79 exploratory wells have been drilled on the Alaskan OCS (table 3). In 1992, two exploratory wells were completed in the Beaufort Sea planning area, testing the Cabot and Kuvlum prospects (fig. 6, table 2).

The majority of the exploratory wells drilled on the Alaskan OCS have been permanently plugged and abandoned. However, eight leases have been classified as "producible" (table 5), although none of them are considered economically productive under current economic conditions. As defined by MMS regulations at 30 CFR 250.11, a "producible" lease is one from which oil, gas, or both, can be produced in quantities sufficient to yield, after completion of the well, a return in excess of the cost of producing the hydrocarbons at the wellhead. All of these producible leases lie within the Beaufort Sea planning area; four of them have been relinquished. Other leases might prove to be "producible," but that determination has not yet been made. 


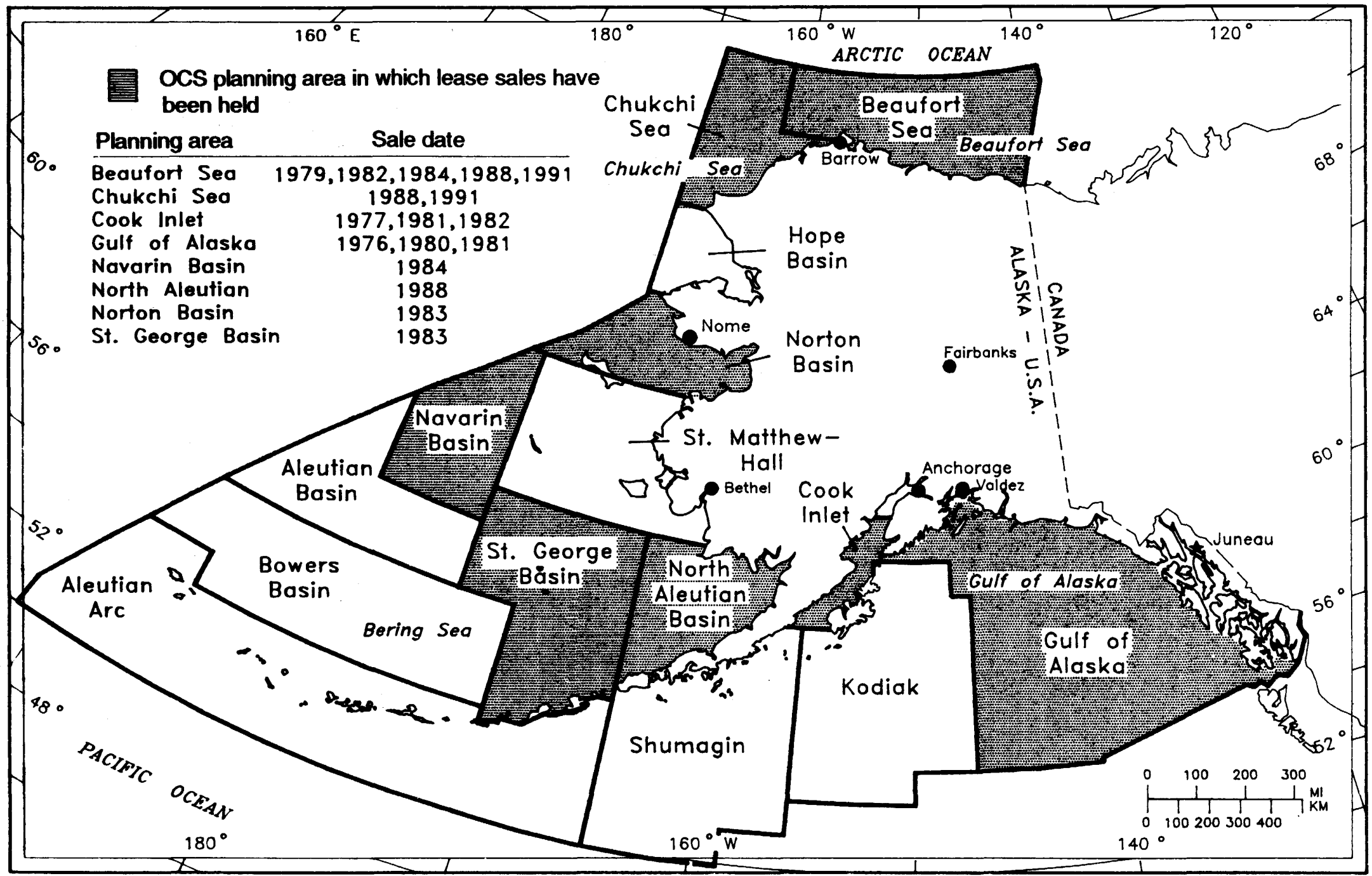

Figure 7. Alaska Outer Continental Shelf Region planning areas and lease sale history. 
Table 3. Alaska Outer Continental Shelf leases and wells drilled, 1976-1992

[DST, Deep Stratigraphic Test well]

\begin{tabular}{|c|c|c|c|}
\hline $\begin{array}{l}\text { Planning area } \\
\text { (sale dates) }\end{array}$ & $\begin{array}{c}\text { Number } \\
\text { of tracts } \\
\text { leased }\end{array}$ & $\begin{array}{l}\text { Number } \\
\text { of wells } \\
\text { drilled' }\end{array}$ & $\begin{array}{c}\text { Number } \\
\text { of active } \\
\text { leases }\end{array}$ \\
\hline $\begin{array}{c}\text { Beaufort Sea } \\
(1979,1982,1984,1988,1991)\end{array}$ & 631 & 26 & 305 \\
\hline $\begin{array}{l}\text { Chukchi Sea } \\
(1988,1991)\end{array}$ & 378 & 4 & 198 \\
\hline $\begin{array}{c}\text { Cook Inlet } \\
(1977,1981,1982)\end{array}$ & 100 & $\begin{array}{l}14 \\
(1 \mathrm{DS}\end{array}$ & T) \\
\hline $\begin{array}{l}\text { Gulf of Alaska } \\
(1976,1980,1981)\end{array}$ & 112 & $\begin{array}{l}13 \\
(1 \mathrm{DS}\end{array}$ & T) \\
\hline $\begin{array}{l}\text { Kodiak Shelf ........................................ } \\
\text { (no sales held) }\end{array}$ & 0 & $\begin{array}{l}6 \\
6 \mathrm{DS}\end{array}$ & T) 0 \\
\hline $\begin{array}{l}\text { Navarin Basin } \\
\text { (1984) }\end{array}$ & 163 & 9 & T) 2 \\
\hline $\begin{array}{l}\text { North Aleutian Basin }{ }^{3} \ldots \ldots \ldots \ldots \ldots \ldots \ldots . . . . . . . . . . .\end{array}$ & 23 & $\begin{array}{ll}1 \\
1\end{array}$ & T) 23 \\
\hline $\begin{array}{l}\text { Norton Basin ........................................... } \\
\text { (1983) }\end{array}$ & 59 & $\begin{array}{l}8 \\
(2 \mathrm{DS}\end{array}$ & T) \\
\hline $\begin{array}{l}\text { St. George Basin } \\
\text { (1983) }\end{array}$ & 96 & 12 & T) 6 \\
\hline
\end{tabular}

Beaufort Sea planning area.-Lease sales were held in the Beaufort Sea planning area in 1979, 1982, 1984, 1988, and 1991. A total of 631 tracts have been leased; 305 remain active. The status of an additional 20 blocks that received bids remains undetermined subject to questions of U.S.-Canadian jurisdiction. OCS Sale 144 is tentatively scheduled for the Beaufort Sea planning area in late 1995.

Twenty-six exploratory wells have been drilled in Federal waters in the Beaufort Sea planning area. ARCO Alaska completed two of those wells in 1992 (fig. 6, table 2): the OCS-Y-0747 No. 1 well on the Cabot prospect 30 miles east of Barrow, and the OCS-Y-0866 No. 1 well on the Kuvlum prospect north of the Arctic NWR. Although the Cabot well was plugged and abandoned, the Kuvlum well has been announced as a new oil discovery. In testing, the well flowed $3,400 \mathrm{bbl} / \mathrm{d}$ with a gas:oil ratio of 17 cubic meters of natural gas per barrel. ARCO Alaska and its partners may drill two delineation wells during the summer of 1993 to determine the size and economic viability of the discovery. An estimated one billion barrels of recoverable oil will be needed for the field to be economic because development costs would be high; a 26-kilometerlong subsea pipeline and a 97-kilometer-long onshore pipeline would be required to transport the oil to the TAPS. Even if the field should prove viable, development will probably take 8 to 10 years.
Table 4. Proceeds from lease sales on Alaska Outer Continental Shelf planning areas

\begin{tabular}{|c|c|c|c|}
\hline Planning area & Sale & Year & $\begin{array}{l}\text { Proceeds } \\
\text { (dollars) }\end{array}$ \\
\hline \multirow[t]{5}{*}{ 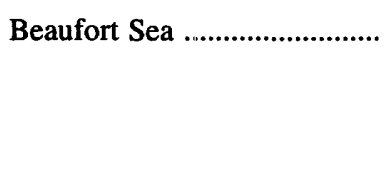 } & $\mathrm{BF}^{1}$ & 1979 & $488,691,138$ \\
\hline & 71 & 1982 & $2,055,632,336$ \\
\hline & 87 & 1984 & $866,860,327$ \\
\hline & 97 & 1988 & $115,261,636$ \\
\hline & 124 & 1991 & $16,807,025$ \\
\hline \multirow[t]{2}{*}{ 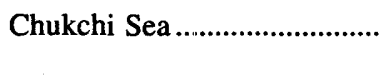 } & 109 & 1988 & $478,032,631$ \\
\hline & 126 & 1991 & $7,117,304$ \\
\hline \multirow[t]{3}{*}{ Gulf of Alaska } & 39 & 1976 & $559,836,587$ \\
\hline & 55 & 1980 & $109,751,073$ \\
\hline & RS1 & 1981 & 170,496 \\
\hline \multirow{3}{*}{ 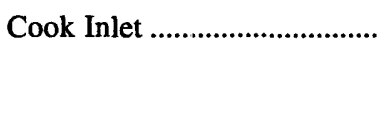 } & CI & 1977 & $398,471,313$ \\
\hline & 60 & 1981 & $4,405,899$ \\
\hline & RS2 & 1982 & 0 \\
\hline 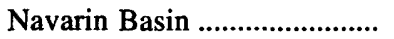 & 83 & 1984 & $516,317,331$ \\
\hline North Aleutian Basin ............. & 92 & 1988 & $95,439,500$ \\
\hline 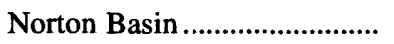 & 57 & 1983 & $317,873,372$ \\
\hline 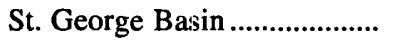 & 70 & 1983 & $426,458,830$ \\
\hline
\end{tabular}

'Held jointly with State of Alaska: total sale revenues $\$ 1,056,082,635$.

Chukchi Sea planning area.-Lease sales in the Chukchi Sea planning area were held in 1988 and 1991. A total of 378 leases were awarded in the two sales; 198 are currently active. A third lease sale, OCS Sale 148 , is tentatively scheduled for mid-1996.

Four exploratory wells have been drilled in the Chukchi Sea planning area; all were plugged and abandoned. The Klondike (OCS-Y-1482 No. 1) well was completed in 1989, the Burger (OCS-Y-1413 No. 1) and Popcorn (OCS-Y-1275 No. 1) wells in 1990, and the Crackerjack (OCS-Y-1320 No. 1) well in 1991. Data obtained from the Klondike well were released to the public by the MMS in 1991 in accordance with 30 CFR 250.3.

Cook Iniet planning area.-In the Cook Inlet planning area, a total of 100 leases were awarded in two lease sales held in 1977 and 1981. In August 1982, a third sale reoffered blocks which had received no bids in the 1981 sale, but no leases were awarded. A fourth lease sale, OCS Sale 88 , initially scheduled for December 1984 , was postponed indefinitely by the Secretary of the Interior due to low industry interest resulting from poor exploration results. There are currently no active leases remaining in the Cook Inlet planning area.

In 1991, ARCO Alaska discovered the first Cook Inlet oil found since 1965, in the Sunfish No. 1 well. ARCO estimates reserves as high as 750 million barrels, which would make the field the fourth largest in Alaska. This discovery, along with improved seismic technology and new geologic interpretations of seismic data, has renewed industry interest in the Cook Inlet planning area. Extendedreach and horizontal well-drilling technology, drilling platform modifications, and upgrades to production equipment 
Table 5. Producible leases, Beaufort Sea planning area

[As defined by MMS regulations at 30 CFR 250.11, a "producible" lease is one from which oil, gas, or both, can be produced in quantities sufficient to yield, after completion of the well, a return in excess of the costs of producing hydrocarbons at the wellhead]

\begin{tabular}{llc}
\hline $\begin{array}{c}\text { Lease } \\
\text { number }\end{array}$ & $\begin{array}{c}\text { Prospect } \\
\text { name }\end{array}$ & $\begin{array}{c}\text { Number of } \\
\text { wells drilled }\end{array}$ \\
\hline OCS-Y-0181 & Seal & 1 \\
OCS-Y-0191 1 & Salmon & 2 \\
OCS-Y-0195 2 & Tern & 1 \\
OCS-Y-0196 2 & Tern & 1 \\
OCS-Y-0197 & Tern & 1 \\
OCS-Y-0370 & Sandpiper & 1 \\
OCS-Y-0371 & Sandpiper & 1 \\
OCS-Y-0849 & Hammerhead & 2 \\
\hline
\end{tabular}

1 Relinquished 12/88.

2 Relinquished $7 / 90$.

${ }^{3}$ Relinquished $6 / 90$.

have also been important in revitalizing interest in the oil potential of Cook Inlet. Both the Federal and State governments plan future lease sales in Cook Inlet. The MMS has scheduled OCS Sale 149 in the Cook Inlet/Shelikof Strait area for late 1994, and the State of Alaska plans an exempt sale to coincide with Sale 149.

Thirteen exploratory wells and one DST well were drilled in the Lower Cook Inlet and Shelikof Strait between 1977 and 1985. All have been permanently plugged and abandoned.

Gulf of Alaska planning area.-A total of 112 leases in the Gulf of Alaska planning area were awarded in three OCS sales held in 1976, 1980, and 1981; all have been relinquished or have expired. OCS Sale 114, a joint Gulf of Alaska/Lower Cook Inlet lease sale originally scheduled for March 1992, was postponed indefinitely in May 1989 to allow additional time to assess the effects of the Exxon Valdez oil spill. Sale 158 is being considered for the Gulf of Alaska/Yakutat area for mid-1995.

Twelve exploratory wells and one DST well were drilled in the Gulf of Alaska between 1975 and 1983. All of these wells have been permanently plugged and abandoned.

Kodiak Shelf planning area.-Six DST wells were drilled on the Kodiak shelf in 1976 and 1977 to delineate the geologic framework and hydrocarbon potential of the area. Four lease sales have been tentatively scheduled for the Kodiak planning area since 1980 but have not been held due to low interest by industry and to administrative postponements. No lease sales are presently scheduled for this area, although the MMS plans to conduct additional studies to gain a better understanding of the hydrocarbon resources of this area.

Navarin Basin planning area.-In the Navarin Basin planning area, 163 leases were awarded in OCS Sale 83 in April 1984. Seventeen additional blocks located within an area of disputed U.S.-Soviet jurisdiction also received bids, but the Secretary of the Interior subsequently concluded that it was not in the interest of the United States to retain the bids, and the bid deposits were refunded with interest in December 1988. Only two leases remain active, but they are due to expire in 1994; the remainder have been relinquished. A second lease sale, OCS Sale 107, scheduled for 1991, has been postponed indefinitely due to low interest by industry.

One DST well was drilled in 1983 and eight exploratory wells in 1985 in the Navarin Basin. All of these wells have been permanently plugged and abandoned.

North Aleutian Basin planning area.-OCS Sale 92 was initially scheduled in the North Aleutian Basin planning area for January 1986. However, a preliminary injunction prohibited opening of bids at that time, and completion of the sale was postponed until October 1988. The 23 leases awarded were placed under a 1-year moratorium and concurrent 1-year suspension of operations from October 1, 1989, to September 30,1990, in order to allow time to study information gathered from Exxon Valdez oilspill studies and to evaluate the environmental consequences of oil development on Bristol Bay fisheries. Three subsequent moratoria have resulted in the suspension of operations in the basin through September 30, 1993. Pending completion of the moratoria and suspensions, lease expiration dates will be extended to the year 2003.

One DST well was completed in the North Aleutian Basin by ARCO Alaska in 1983. No exploratory wells have been drilled due to the moratoria.

Norton Basin planning area.-Fifty-nine leases were awarded in the Norton Basin planning area in 1983 in OCS Sale 57; all have been relinquished. Two additional lease sales, OCS Sale 100 and OCS Sale 120, were scheduled for 1986 and 1992, respectively, but were canceled or indefinitely postponed due to low industry interest. Two DST wells were drilled by ARCO Alaska in Norton Basin prior to OCS Sale 57. Six exploratory wells were drilled in 1984 and 1985 on leases acquired by Exxon and ARCO Alaska; all of these wells have been permanently plugged and abandoned.

Saint George Basin planning area.-In the Saint George Basin planning area, 96 leases were awarded in OCS Sale 70, held in 1983. Six leases remain active but are due to expire in 1994. Two additional scheduled lease sales, OCS Sale 89 and OCS Sale 101, were canceled or postponed indefinitely in 1986 and 1990, respectively, due to low industry interest. OCS Sale 153 is being tentatively considered for late 1996. Ten exploratory wells and two DST wells, all now permanently plugged and abandoned, were drilled in the Saint George Basin planning area prior to 1986.

\section{FUTURE LEASE SALES}

The OCS Lands Act requires that the DOI prepare a 5-year program that specifies the size, location, and sched- 
uling of areas to be assessed for Federal offshore natural gas and oil leasing. In response, the MMS has prepared a comprehensive program for the management and leasing of natural gas and oil on the Alaskan OCS, 1992-1997 (Minerals Management Service, 1992). The proposal limits the amount of acreage offered for lease by excluding areas where resource potential and industry interest are low, thus reducing uncertainty about potential effects on other natural resources. Compared to previous 5-year programs, fewer sales will be considered in fewer areas.

Leasing will be considered in 6 of the 15 Alaskan OCS planning areas during 1992-1997 (fig. 8). One sale each will be considered for Lower Cook Inlet/Shelikof Strait (late 1994), Saint George Basin (late 1996), the Gulf of Alaska/Yakutat Area (mid-1995), the Beaufort Sea (late 1995), the Chukchi Sea (mid-1996), and Hope Basin (mid1997). Actual dates will depend on the outcome of the Area Evaluation and Decision process.

No leasing will be considered for the remaining planning areas, but studies are planned for Gulf of Alaska (Middleton Island area), Kodiak, Navarin Basin, North Aleutian Basin, Norton Basin, Saint Matthew-Hall, and Shumagin. The studies are intended to focus on the hydrocarbon potential and environmental characteristics of these areas.

\section{OIL AND GAS RESOURCE ASSESSMENT}

The MMS prepares estimates of the undiscovered, economically recoverable oil and gas resources on the OCS as part of the Federal National Oil and Gas Resource Assessment. The results of the 1987 assessment were released in Mast and others (1989). In late 1989, the MMS initiated a review of OCS undiscovered-resource estimates to determine if newly available geologic and geophysical information would warrant an update. Based on information available as of January 1990, new data for three Alaskan OCS planning areas significantly changed the 1987 estimates; the revised estimates were released in OCS Report MMS 91-0051 (Cooke, 1991). The next complete national assessment is scheduled for 1995.

DATA ACQUISITION ON THE ALASKAN OCS

Geophysical exploration on the Alaskan OCS, which had reached a 28-year low in 1991, rebounded in 1992 when industry acquired 2,832 line-kilometers of seismicreflection data in Federal waters. Seismic activity was limited to the Lower Cook Inlet (2,803 line-kilometers) and the inner-central Beaufort shelf, where exploration focused on areas adjacent to or extending shoreward into State waters. No permits for regional gravity or magnetic surveys were issued by the MMS for the Alaskan OCS in 1992.

Several factors have affected Alaskan OCS exploration activity: (1) the relatively high cost of exploration and production in the offshore Alaska environment is prohibitive under the present economic conditions; (2) initial investigations in Alaskan OCS waters have reached a mature stage, especially with respect to understanding the geologic framework and petroleum potential of individual sedimentary basins; and (3) no economic hydrocarbon discoveries had been announced on the Alaskan OCS until the Kuvlum discovery in late 1992.

\section{JOINT FEDERAL-STATE STUDIES}

In 1975, the MMS (then Conservation Division, USGS) and the State of Alaska initiated joint geologic studies along certain coastal areas of Alaska where geologic data were of mutual interest and where such data promised insights into the petroleum potential of adjacent onshore and offshore areas. Subsequent collaborations have investigated areas including the Gulf of Alaska, Cook Inlet, Kodiak Islands (Kodiak shelf), Seward PeninsulaKuskokwim drainage (Norton Basin), Pribilof Islands (Saint George Basin), Alaska Peninsula (North Aleutian Basin), Waring Mountains (Hope/Selawik Basins), and the northeastern Brooks Range (Kaktovik Basin). Since 1984, the cooperative work has been funded by grants from the MMS-sponsored Studies Related to Continental Margins Program (SRCMP). Studies funded under SRCMP are administered by the Bureau of Economic Geology, University of Texas at Austin, and performed by the ADGGS. In recent years, SRCMP studies have focused on the geology of the Arctic Slope and the Arctic NWR. Detailed geologic mapping and fission-track studies of this area have provided insight into the thermal evolution of the Beaufort continental margin, particularly as it bears on the maturation history of key source-rock sequences (O'Sullivan, 1988; O'Sullivan and others, 1989; Clough and others, 1990). Phase II of the regional study was initiated in 1991 and focuses on glauconite radiometric dating of the Lower Cretaceous unconformity surface and bounding strata in the Prudhoe Bay area, in the Arctic NWR adjacent to the coastal plain, and westward along the northern foothills of the Brooks Range.

\section{ENVIRONMENTAL STUDIES PROGRAM}

The Alaska Environmental Studies Program (ESP) was created by the DOI in 1974 in response to the Federal Government's decision to lease areas of Alaska's OCS for gas and oil development. The purpose of the ESP is to determine information needs and implement studies to assist in predicting, assessing, and managing potential effects of oil and gas exploration and development on the human, marine, and coastal environments of Alaska and the Alaskan OCS. Although the ESP is administered by the MMS, additional assessment information is provided to the Alaskan ESP by the National Oceanic and Atmospheric 


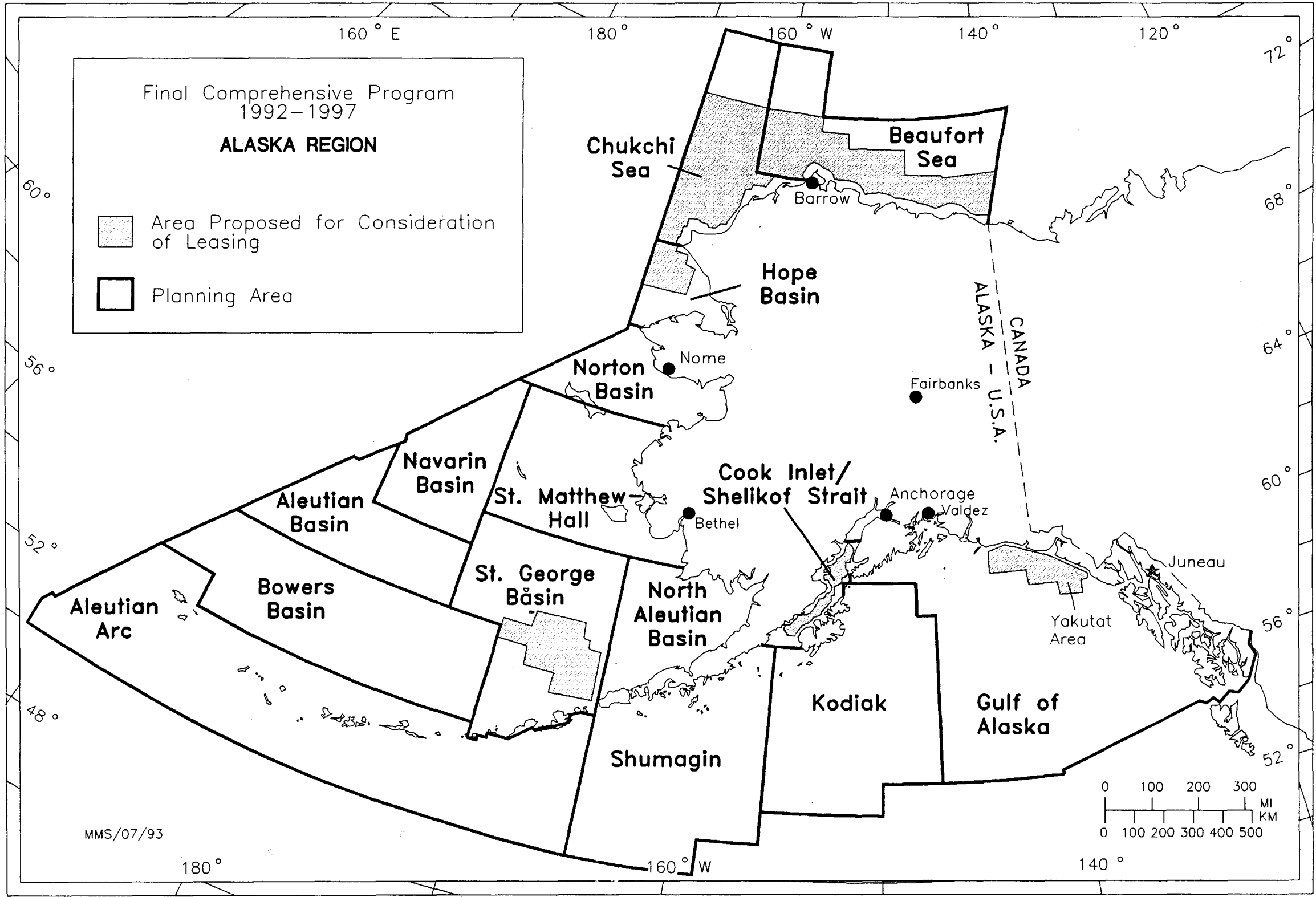

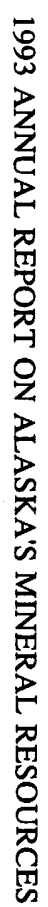

Figure 8. Areas proposed by the MMS for future lease sales or geological and environmental studies, 1992-1997. Information current to January 1, 1993 . 
Administration (NOAA) and through direct contracts with private enterprises.

The initial objective of the ESP was to obtain baseline information on the biological resources and physical characteristics of the Alaskan environment. These studies included biological surveys of marine species, basic oceanography and meteorology, and investigations of geologic and sea-ice phenomena. As the OCS leasing program was accelerated in the late 1970's and early 1980's, the emphasis of ESP studies shifted to the potential effects of oil contamination on biological resources and to the probable transport and dispersion of oil that might be spilled in the marine environment.

As the Alaskan OCS leasing program matures and significant exploration activity declines, the mission of the Alaskan ESP has been to conduct postlease studies in order to monitor the possible effects of gas and oil drilling and exploration activities on the OCS environment and its resources. ESP studies can be categorized into several broadly defined subjects: living resources, endangered species, environmental geology, ecosystems, pollutant transport, environmental monitoring, oil-spill fate and effects, and social and economic studies. Descriptions of ongoing and proposed ESP studies in Alaska are presented in “Alaska Regional Studies Plan-Final, FY 1993" (Minerals Management Service, 1992).

\section{U.S. GEOLOGICAL SURVEY}

Current USGS research of onshore oil and gas resources in Alaska focuses on the North Slope, basins of interior Alaska, gas hydrates, and the geologic thermal evolution of Alaska. These projects are funded under the Onshore Oil and Gas Investigations, the Climate Change, and the Alaska Mineral Resource Assessment programs. During 1992, USGS scientists conducted laboratory analyses of samples collected in the field and prepared several maps and reports. Research highlights were presented during 1992 at the USGS McKelvey Forum in Houston and at meetings of the American Association of Petroleum Geologists, the American Geophysical Union, and the Cordilleran Section of the Geological Society of America. All papers listed in the following five sections on USGS research are catalogued in appendix 1 under the USGS heading.

\section{NORTH SLOPE}

Five geologic traverses on the North Slope will allow USGS geologists to analyze the oil and gas potential of the Brooks Range foothills region (fig. 9). Most of the field work for the first traverse, in the Dalton Highway area, has been completed. Preliminary findings of investigations have been reported (Howell, Bird, and others, 1992; Bird, Howell, and others, 1992). In the laboratory, vitrinitereflectance analyses were performed to further constrain the thermal history of the region, and petrographic analyses of sandstones were begun in order to evaluate reservoir potential. A general summary report on the North Slope foreland basin was published (Bird and Molenaar, 1992).

For the Prudhoe Bay-Kuparuk River area, results of borehole gravity measurements in the (informal) West Sak and (informal) Ugnu sands were presented (Beyer, 1992); possibly the first onshore occurrence of the well-known "offshore bottom-simulating reflector," a seismic reflection associated with gas hydrates, was described (Bird and Collett, 1992); and the Jurassic braided-stream deposits in the Morrison Formation of southern Utah were suggested as an analog to the Sadlerochit reservoir in the Prudhoe Bay oil field (Robinson and McCabe, 1992). In NPRA, geothermal gradients and heat flow calculations are consistent with basin-scale, topographically driven groundwater flow from the foothills north to the coastal plain (Deming, Sass, and Lachenbruch, 1992). Near Point Barrow, the circular, subsurface feature known as the "disturbed zone" was interpreted as a buried meteorite impact structure (Kirschner, Grantz, and Mullen, 1992); the Barrow gas fields are located in structures forming the rim of the zone.

\section{INTERIOR ALASKA}

USGS scientists continued work on a newly compiled map of the geology and gravity of the Nenana basin of central Alaska. This map updates some of the geological information already presented (Frost and Stanley, 1991) and shows isostatic, rather than Bouguer, gravity. An isostatic gravity map effectively removes strong regionalgravity gradients, such as those produced by the roots of the Alaska Range, thereby providing a clearer picture of the locations and sizes of thick accumulations of low-density Tertiary rocks that represent potential petroleum basins. Aspects of the sedimentary petrology, depositional environments, and energy resource potential of Tertiary rocks in the Nenana basin area were discussed in published reports (McLean and Stanley, 1992; Stanley, Flores, and Wiley, 1992).

Studies in the Kandik region of east-central Alaska focus on thermal-maturity and sedimentologic data in order to constrain the tectonic history of this fold-andthrust belt and to understand its relationship to similar geologic provinces in the Brooks Range to the north and the Cordillera to the south. Preliminary findings of this research have been published (Howell, Johnsson, and others, 1992; Underwood and others, 1992; Shelton and others, 1992).

\section{GAS HYDRATES}

Through the use of well logs, the North Slope Gas Hydrate Project has documented the occurrence of natural gas hydrates in multiple sandstone reservoirs at shallow 
depth in the region overlying the Prudhoe Bay and Kuparuk River oil fields. The amount of natural gas in these hydrates is estimated at 1.1 trillion cubic meters, equivalent to the total volume of gas in all conventional oil and gas fields on the North Slope. Research results and a major synthesis report have been published or are in press (Collett, 1992a, 1992b, 1992c; 1993). More than 5,000 gas analyses from the hydrate zone in the Prudhoe-Kuparuk area, along with an interpretation of the data, have also been published (Valin and Collett, 1992). In the same Prudhoe-Kuparuk area, seismic data supplied by the Exxon Corporation provide evidence of free gas trapped below a hydrate seal (Bird and Collett, 1992). Field work during 1992 included (1) the collection and analysis of rock and gas samples from one of the Walakpa gas field development wells; (2) the collection of 36 shallow cores near the Prudhoe Bay oil field to characterize the seasonal gas flux from underlying hydrate accumulations; and (3) the establishment of four gas-flux monitoring stations over the Eileen fault system. The North Slope Gas Hydrate Project is funded by the Onshore Oil and Gas Investigations program, the DOE, and the Climate Change program.
To understand better the habitat of hydrates, the Canadian Geological Survey sponsored a drilling program in the Mackenzie River Delta; one USGS scientist participated in coring and recovering hydrate samples from several gas-hydrate-bearing intervals. An exchange program with Russian hydrate specialists resulted in the completion of several jointly authored reports comparing Alaskan with Russian hydrate occurrences.

\section{THERMAL-MATURITY MAP OF ALASKA}

A generalized thermal-maturity map of Alaska was completed and submitted for USGS publication (Johnsson and Howell, in press); the completed map utilized nearly 10,000 vitrinite-reflectance and conodont color alteration index determinations from some 3,500 outcrop localities and 214 wells to portray the thermal maturity of rocks exposed at the surface. For the North Slope and Cook Inlet, data permitted the map to show the configuration of the top of the oil window in the subsurface. The map and data will provide clues to tectonic history and hydrocarbon potential throughout the state. The data used to compile the

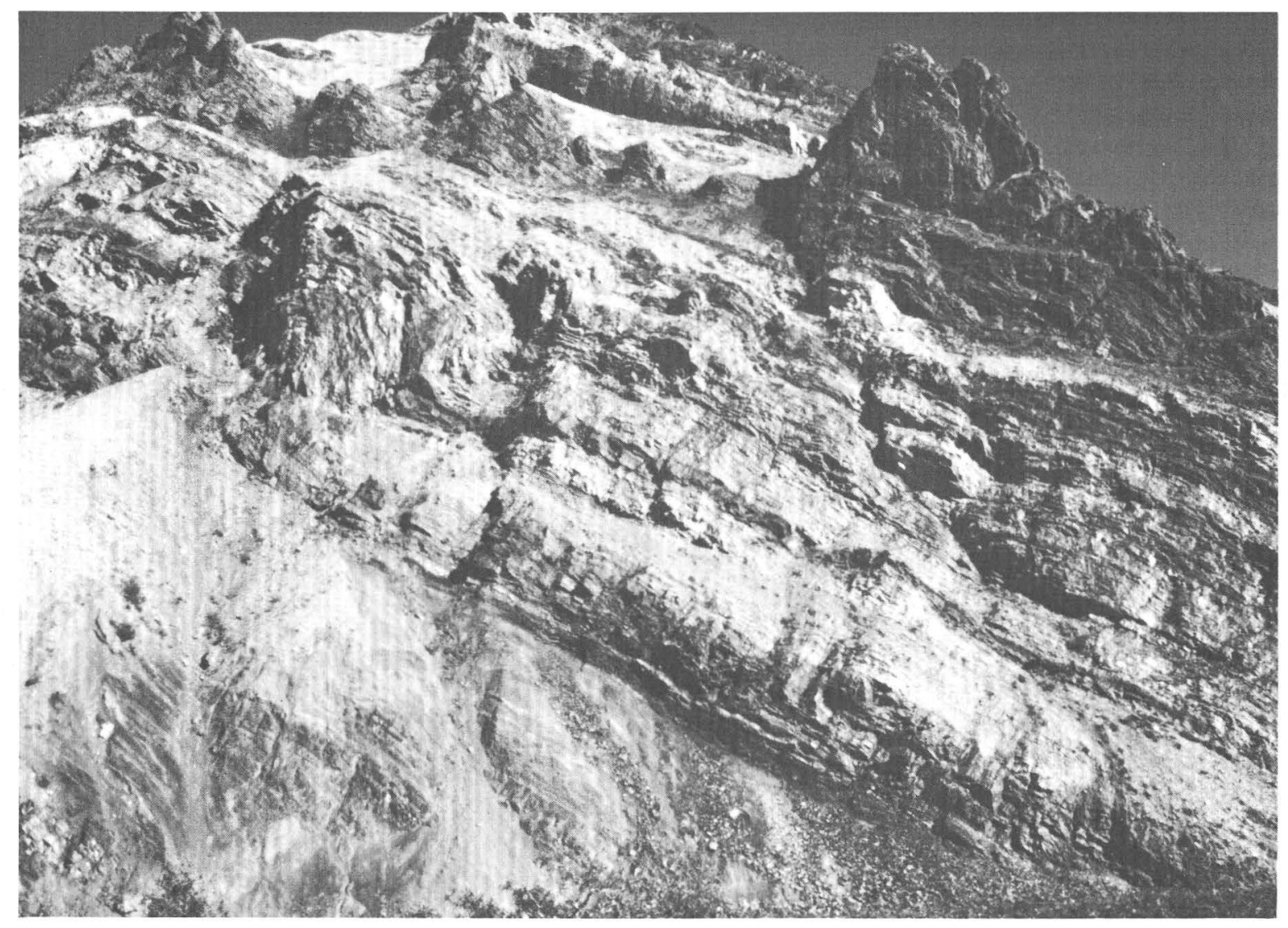

Figure 9. Outcrop of Lisburne Group in the Ivotuk Hills, Killik River quadrangle, where USGS geologists are evaluating the oil and gas potential of sedimentary rocks in the northern foothills of the central Brooks Range. Photograph by J. Dumoulin. 
map were published (Johnsson and others, 1992), and another report describes some of the more salient features of the map (Johnsson, Howell, and Bird, 1993).

\section{OIL AND GAS RESOURCE ASSESSMENT}

Several reports providing additional details of the Alaskan portion of the 1987 national oil and gas resource assessment were completed in 1992. An analysis of economically recoverable oil resources on the North Slope was published (Attenasi, Bird, and Mast, 1993), as was the volume providing details of individual petroleum plays in the assessment (Powers, 1993). Alaskan plays described in this volume are on the North Slope (Bird, 1993a, 1993b, 1993c), in interior Alaska (Fisher 1993a; Magoon, 1993a, 1993b), and in southern Alaska (Bruns, 1993a, 1993b; Fisher, 1993b; Magoon, 1993c, 1993d; and Magoon and McLean, 1993).

\section{BUREAU OF LAND MANAGEMENT}

The BLM's Division of Mineral Resources publishes resource reports for various areas around the state; the following reports are listed in appendix 1, BLM section. In 1992, the Division published the leasable mineral resource assessment of the 141,641-square-kilometer South-Central planning area (Diel, 1992), as well as the oil and gas assessment of the Utukok Special Management Area of NPRA (Bascle and Foland, 1992). Similar oil and gas assessments will be published in the near future for the Teshekpuk Special Management Area of NPRA and for the 121,406-square-kilometer Forty Mile/Black River planning areas. Geologists from the BLM participated at the American Association of Petroleum Geologists Convention in Calgary and presented papers at the International Conference on Arctic Margins in Anchorage on the petroleum geology, geochemistry, and petrology of rocks pertinent to the resource assessment of the 1002 area of the Arctic NWR in northeastern Alaska (Banet, 1992b, 1992c; Mowatt and Banet, 1992; Mowatt, Banet, and Reeder, 1992b; Mowatt, Bascle, and Gibson, 1992). The BLM also reviewed all new and reprocessed geologic data pertinent to the 1002 area and its immediate vicinity.

The BLM continues to monitor interest in an NPRA lease sale. In anticipation of such a sale, BLM geologists and geophysicists are evaluating approximately 2,023 square kilometers that have known oil and gas potential. In addition, BLM geologists completed four appraisals of the subsurface estate in support of land exchanges and continued their work on an automated mapping and mineralsinventory data base.

The BLM's Alaska Inspection and Enforcement (I\&E) Program governs operations associated with the exploration, development, and production of oil and gas deposits from Federal leases in Cook Inlet. The I\&E Strategy prioritizes the relative importance of various factors pertaining to leasehold operations, such as production volume, other resources, and operator compliance with health and safety, environmental, and legal requirements; the Automated Inspection Record System tracks field inspection data. The I\&E Program is currently overseeing the development of the Sterling gas unit into a producing field by 1993. The BLM anticipates further development activities due to growing demand for natural gas in the Cook Inlet area. The I\&E Program also cooperates with the Alaska Department of Environmental Conservation in researching information pertaining to the State's well-site closure program.

The Branch of Lease Operations within the BLM's Division of Mineral Resources has developed a computer program that will retrieve data from the Petroleum Information Data Base and then export the information to other analytical and mapping software programs. This new data base retrieval program is available and applicable for similar uses by all BLM field offices. The Branch has also initiated a sophisticated well-log-analysis computer program and has cooperated with the State of Alaska in reviewing and assessing the condition of various plugged and abandoned wells drilled on Federal lands throughout Alaska, including NPRA.

The Branch of Pipeline Monitoring is part of the BLM's Division of Mineral Resources. The Branch's principal function is to ensure compliance with the terms and conditions of the Right-of-Way Grant issued to the Alyeska Pipeline Service Company for TAPS. To accomplish this, the Branch works with the JPO to develop and implement a coordinated monitoring program. The new requirements of the oil-spill contingency plan have been implemented, and a heightened awareness of oil-spill effects and remedies is evident throughout TAPS. Work continues on wetlands mapping and processing of the Federal Energy Regulatory Commission application for the Anderson Bay LNG facility near Valdez. Activities regarding the TAGS project were scaled back when the startup date was postponed. For a copy of the Annual Report of the Branch of Pipeline Monitoring, contact the BLM Public Affairs Office in the Federal Building in Anchorage (222 W. 7th Street, Box 13, Anchorage, AK 99513).

In establishing and implementing an oil and gas leasing program as required by Section 1008 of ANILCA, the BLM has made land available for noncompetitive oil and gas leasing in four areas south of latitude $68^{\circ} \mathrm{N}$ (fig. 10). Both the Minchumina and the Denali-Tiekel-Slana areas were opened in 1982, the Seward Peninsula in 1983, and the Iditarod-George area in 1990, totaling 37,653 square kilometers open to oil and gas leasing. As of September 30,1992 , the BLM had 2,779 nonproducing leases on 1,625 square kilometers in these areas. The BLM also maintains 34 producing leases on the Kenai Peninsula; of these, 23 are in production comprising 198 square kilometers, 
and 11 are allocated production within 53 square kilometers. Except for the NPRA, all BLM-administered oil and gas estates in Alaska are now handled under the leasing system established by the Federal Onshore Oil and Gas Leasing Reform Act of 1987 and the Energy Policy Act of 1992. Drilling and production operations on BLM leases are administered through the BLM's Branch of Lease Operations.

\section{U.S. FISH AND WILDLIFE SERVICE}

KENAI NATIONAL WILDLIFE REFUGE

The Kenai NWR is the only refuge in Alaska where commercial oil and gas production currently is permitted. Surface operations here are regulated by the FWS, and subsurface activities by the BLM. In 1992, a Compensatory Royalty Agreement was completed with CIRI in order to resolve the drainage case that arose when CIRI drilled two wells that pumped oil from adjoining Federal subsurface estates. Data for 1992 production from the refuge's Swanson River and Beaver Creek oil fields were previously given in the section "Production: Cook Inlet."

Refuge personnel and other FWS staff reviewed an environmental assessment prepared by ARCO Alaska for their proposed Stormy Lake East exploratory well pad and road south of the Swanson River field. No permits were issued by the FWS in 1992 for this well.

At the Swanson River oil field, then operated by ARCO Alaska, soils contaminated by polychlorinated biphenyls (PCB's) were discovered in 1985. Excavation and stockpiling of the contaminated soils were completed in early 1992 , and more than 90,718 metric tons were neutralized by a circulating-bed combustor. The combustor was dismantled and removed by August 1992, at which time the site was rehabilitated through landscaping, fertilization, and replanting. At the same field, an aromatic hydrocarbon spill was discovered in the pipe and supply yard in 1990. Initial efforts to remove the hydrocarbons with an air-stripping unit were successful, and site remediation is expected to continue until established cleanup levels are achieved. UNOCAL now operates the Swanson River field.

A diesel fuel spill was discovered in 1990 in the Beaver Creek field, which is operated by Marathon Oil; the company's remediation plan should be ready for agency review in late 1993. Marathon Oil also intends to drill a new well in the field in 1993.

In 1991, then-owner ARCO Alaska completed an environmental audit of chronic crude oil spills and leaks at tank settings and flare pits throughout the Swanson River field. A remediation pilot project was initiated in 1992 at one of the seven tank settings, and project results will be used to develop a comprehensive strategy in 1993. As the field's new operator, UNOCAL also plans to begin gas production in 1993.

\section{ACTIVITIES UNDER SECTION 1008 OF ANILCA}

Section 1008 of the ANILCA provides for oil and gas studies on refuges in Alaska to gather information for use in future land-management decisions. In 1992, 17 specialuse permits were issued for mineral activities on the following national wildlife refuges (number of permits in parentheses): Alaska Peninsula/Becharof-surface geology (1), temporary transponder placement (1); Arcticsurface geology by industry (4), surface geology by universities (4), navigation towers (2), helicopter VIP tours (4); Kanuti-surface geology by government agency (1). All special-use permits include specific stipulations to ensure that the permitted activities remain compatible with the purposes of the refuges and to protect refuge resources and refuge users. Commercial permittees must post bonds. Copies of all data gathered from refuge activities must be submitted to the FWS. After review by the FWS, the data are provided to the BLM for confidential storage.

\section{RESOURCE ACTIVITY IMPACT ASSESSMENT}

Permitting.-In 1992, the FWS commented on 23 Section 404 Clean Water Act permits dealing with oil and gas activities off refuges. These included 22 individual permits and one general permit. Activities covered by these permits included oilfield activities at the Prudhoe Bay, Kuparuk, Endicott, Lisburne, Milne Point, and Point McIntyre fields, as well as the TAPS. The FWS also reviewed one North Slope Borough oil and gas permit application.

Lease Sales. - The FWS reviewed and commented on Federal OCS Lease Sale 149 in Cook Inlet and on 14 proposed State oil and gas lease sales.

Monitoring.-The FWS conducts onshore and offshore environmental monitoring of contaminants introduced to fish and wildlife habitat from oil and gas activities. On the Kenai NWR, contaminant monitoring on six projects continued through 1992. The FWS also conducted water quality monitoring of migratory bird habitat in the Prudhoe Bay and Kuparuk oilfields. The FWS is in the process of developing the Biomonitoring of Environmental Status and Trends (BEST) Program, which will systematically monitor contaminant concentrations in selected environmental matrices. The information generated by the BEST Program will be used to assess the environmental impacts of development projects, be they for oil and gas resources or other activities.

Reclamation.-On the Arctic NWR, FWS personnel continued to monitor the progress of revegetation efforts at the Kaktovik Inupiat Corporation's exploratory well.

Regulation.-No Letters of Authorization were issued in 1992 under the 1991 Chukchi Sea regulations for the incidental take of small numbers of walruses and polar bears during open-water exploration for oil and gas in the Chukchi Sea adjacent to the coast of Alaska. In December 
1991, BP Exploration petitioned the FWS for promulgation of regulations that would allow the incidental, but not intentional, take of small numbers of (1) Pacific walrus and polar bears in the course of oil and gas exploration activities during the open-water season in State waters and on the Beaufort Sea OCS adjacent to the coast of Alaska; (2) polar bears in the course of oil and gas exploration activities in Arctic Alaska (onshore and offshore) during the ice-covered period of the year; and (3) polar bears and walrus in the course of oil and gas development and production activities and associated vessel operations in Arctic Alaska on a year-round basis. The FWS reviewed the petition and prepared a draft environmental assessment in conjunction with the proposed rule. The three-part petition was combined into one action that proposed regulations to authorize for the next 5 years the incidental and unintentional take of small numbers of polar bears and walrus during oil and gas exploration, development, and production activities year-round in the Beaufort Sea and adjacent northern coast of Alaska. The coast along the boundary of the Arctic NWR is excluded from the petition and regulations. The environmental review process led the FWS to conclude that the projected takings would have a negligible impact on the species populations and would not have an unmitigable adverse impact on the availability of such populations for subsistence uses. On December 30, 1992, the FWS published the proposed rule, notice of public meeting, and request for comments on BP Exploration's petition in the Federal Register.

\section{NATIONAL PARK SERVICE}

The NPS provided comments to the State of Alaska and to the MMS on proposed oil and gas lease sales that were scheduled near national park units. The NPS met with ARCO Alaska regarding exploration for oil and gas on Doyon-owned lands within Yukon-Charley Rivers National Preserve.

\section{DEPARTMENT OF ENERGY}

A primary petroleum target is the gas-hydrate reservoir, which contains gas in a solid, icelike form; occurrences of these hydrates have been identified on Alaska's North Slope (fig. 10). The DOE is investigating the technology for characterizing and developing this resource as part of its Natural Gas Technology Research subprogram. The study strives to delineate and define the geophysical and mechanical properties of the hydrates and their reservoirs (Malone, 1990). Using both in-house and contractors' facilities, scientists conduct laboratory tests on natural and synthetic gas hydrates to characterize the pressure and temperature conditions necessary for their formation and dissociation. In addition, arctic research studies to determine in-place conditions of gas-hydrate deposits have been initiated by the DOE in cooperation with the USGS, ARCO Alaska, BP Exploration, Exxon, and Conoco. A study of the hydrate potential of the Walakpa gas field in northwestern Alaska has been published (Glenn and Allen, 1992a).

As part of DOE-funded research, Geoexplorers International has conducted a series of studies, and the resultant geologic basin reports have been published in a 15-volume series titled "Geological Evolution and Analysis of Confirmed or Suspected Gas Hydrate Localities." The summary report (Finley and Krason, 1989) presents an overview of known geologic gas-hydrate parameters; two other volumes deal with gas hydrates in the Aleutian Trench and Bering Sea (Krason and Ciesnik, 1987) and in the Beaufort Sea (Krason and Finley, 1989).

\section{ARCTIC NATIONAL WILDLIFE REFUGE}

During development and passage of the ANILCA, the coastal plain of the Arctic NWR in northeastern Alaska was the subject of conflicting interests; these ranged from designating the area as wilderness to leaving the area open for oil and gas development. As a result, Section 1002 of the ANILCA sets out specific management constraints on a 6,070-square-kilometer strip within the coastal plain of the 78,914-square-kilometer Arctic NWR. This portion of Arctic NWR's coastal plain is frequently referred to as the 1002 area (fig. 6). Section 1002 requires that the Secretary of the Interior (1) conduct a comprehensive, continuing baseline study of the fish and wildlife resources of the 1002 area; (2) develop guidelines to initiate and monitor an oil and gas exploration program; and (3) prepare a report to Congress describing the fish, wildlife, and hydrocarbon resources, the potential impacts and development scenario for petroleum exploration and production, and recommendations regarding possible oil and gas exploration, development, and production, should those activities be allowed in the 1002 area.

The FWS was designated as principal coordinator for the Section 1002 resource assessment and conducted a baseline study of the area's fish, wildlife, and habitats. The Report to Congress (Clough and others, 1987) was prepared under the provisions of a 1983 interagency memorandum of understanding among the FWS, BLM, and USGS. Specific agency roles and research are described in that report. The Secretary recommended that the 1002 area should be opened to an orderly oil and gas leasing program in a manner that would avoid unnecessary adverse effects on the environment. During 1992, Federal agency activities regarding the 1002 area focused on responses to inquiries regarding the final report findings and on continuing a research and study program. 


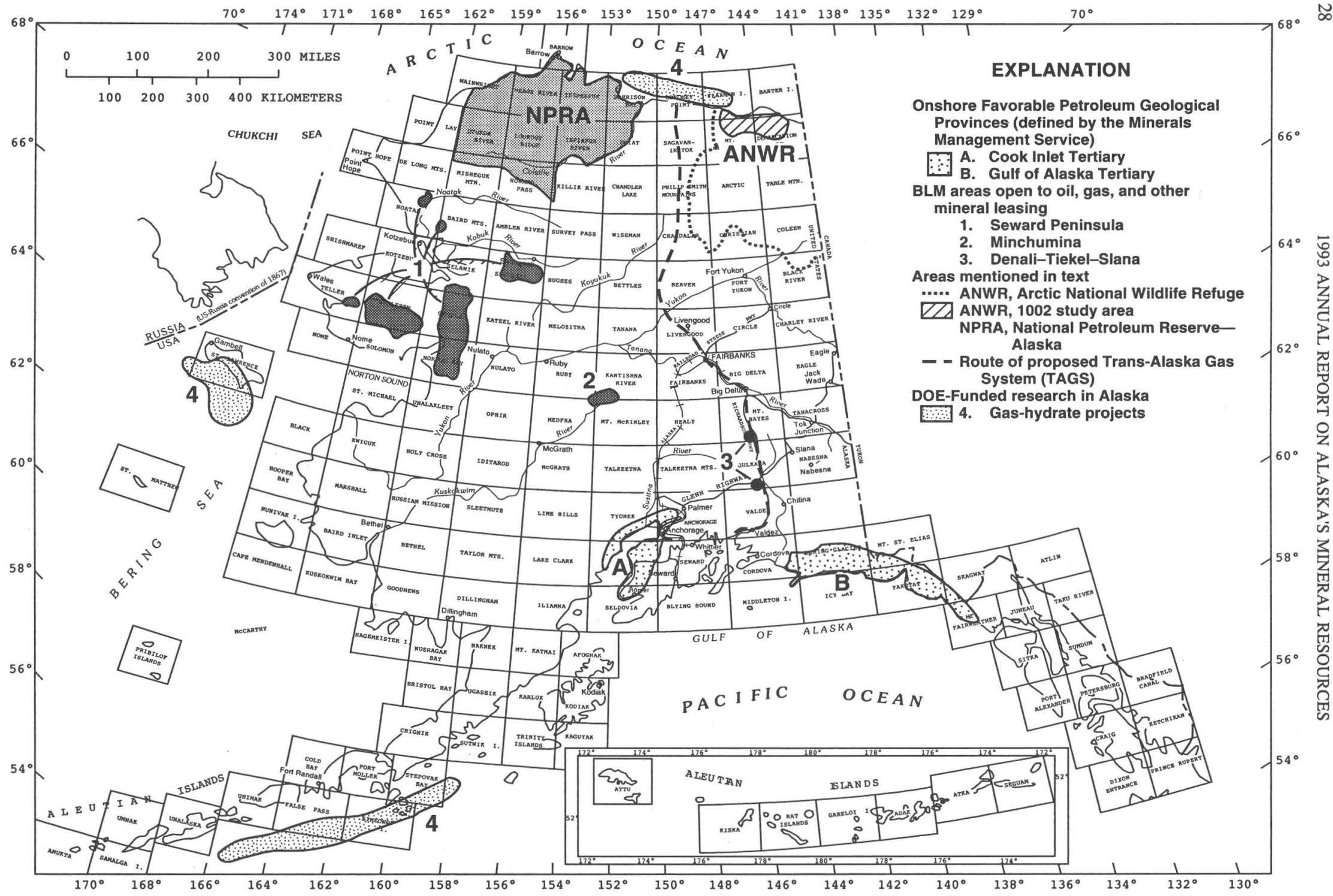

Figure 10. Onshore favorable petroleum provinces, land units referred to in text, and locations of DOE-funded research in 1992. 1:250,000-scale quadrangles are outlined and labeled. 


\section{ACTIVITY BY FEDERAL AGENCIES}

U.S. FISH AND WILDLIFE SERVICE

During 1992, the FWS continued to respond to congressional inquiries concerning the potential for, and impacts from, oil and gas leasing and development on the Arctic NWR's coastal plain. Since 1987, Congress has considered a variety of legislative measures that sometimes reflect the controversy surrounding the disposition of the area. Legislative work in 1992 resulted in the Energy Policy Act of 1992, which did not include any provisions dealing with the Arctic NWR. Legislation was introduced in the 103rd Congress to designate the area as wilderness. While the debate continues, the ANILCA prohibits further oil and gas activities on the 1002 area until authorized by an act of Congress.

Recognizing that a variety of regulatory and planning processes would immediately be initiated if legislation is passed that opens the coastal plain to oil and gas activities, the FWS continues to pursue biological studies in the area. The goal of these studies is to achieve a better understanding of the area's natural dynamics, the altered ecosystem dynamics that might result from oil and gas activities, any associated adverse impacts, and the means to avoid, minimize, or rectify those adverse impacts. In 1992, the FWS completed the fifth year in its 5-year continuing study program. These studies include caribou, muskox, and polar bear population dynamics; habitat mapping; polar bear denning; snow goose migration; coastal area fish activities; vegetation recovery from 1984-85 seismic activities; water resources quantification; baseline contaminants; and tundra swan nesting and brood rearing. Reports recently released (see appendix 1, FWS section) include a final report on the effects of port sites on migratory birds (Willms, 1992) and an interim report on terrestrial studies, including caribou, muskox, polar bears, snow geese, tundra swans, and habitat (McCabe and others, 1992). Other publications in appendix 1, FWS section, also provide data and information on the resources of the 1002 area (Everett, 1990; Felix and others, 1992; Lyons and Trawicki, 1991, 1992; McCabe and others, 1993; Underwood and others, 1992; Walsh and others, 1992; Wiswar, 1991, 1992).

\section{EXXON VALDEZ OIL SPILL}

The oil tanker T/V Exxon Valdez ran aground on Bligh Reef on March 24, 1989, spilling more than 41,640 cubic meters (262,000 barrels) of Prudhoe Bay crude oil into eastern Prince William Sound. Containment efforts failed, and oil from the tanker eventually impacted large areas of coastline in Prince William Sound, the Gulf of Alaska, the Kodiak Archipelago, and the Alaska Peninsula. Exxon spent over $\$ 2$ billion on cleanup operations in 3 years and was ordered in October 1991 to pay over \$1 billion in fines ( $\$ 25$ million), restitution ( $\$ 100$ million), and civil damages ( $\$ 900$ million) to the Federal and State governments. Exxon has paid the fine and restitution monies, and paid \$110 million in December 1992 as its second installment on the civil settlement; payments are to continue until the year 2001 (Anchorage Daily News, December 2, 1992).

Although most of the oil spilled is no longer obvious, toxic oil continues to be found in some environmentally important areas such as mussel beds. The long-term effects of the spill will continue to be a topic of study and controversy. The U.S. Coast Guard (USCG), as the Federal onscene coordinator, and the State of Alaska's on-scene coordinator officially announced on June 14,1992 , that the response phase of the Exxon Valdez oil spill cleanup was completed satisfactorily.

\section{ACTIVITY BY FEDERAL AGENCIES}

U.S. FISH AND WILDLIFE SERVICE

During the fourth year following the Exxon Valdez oil spill, the FWS remained actively involved with the USCG Federal on-scene coordinator in assessing the status of national wildlife refuge shorelines and in monitoring cleanup activities. Other programs were undertaken to protect DOI trust resources. Additionally, the FWS continued natural resource damage assessment and restoration planning. Investigations by FWS personnel focused on migratory birds and sea otters, the two trust resource groups most affected by the oil spill.

The FWS worked closely with the USCG and Exxon to protect nesting bald eagles and seabird colonies from disturbance caused by cleanup activities. Surveys were conducted to map the locations and status of eagle nests and seabird colonies, and protective measures were implemented to minimize disturbance. Buffer zones and timing constraints were established to exclude human activity, including aircraft movement. When conflicts developed between the need to protect and the need to decontaminate ecologically sensitive areas (for example, anadromous fish streams), a monitoring system was implemented to allow cleanup while providing a mechanism to pull out the workers if eagles displayed disturbance behavior.

The FWS led the natural-resource damage assessment activities for the DOI until the October 1991 settlement with Exxon. The FWS continued studies on sea otters and migratory birds and cooperated with the other trustee agencies in providing important hydrocarbon analysis and mapping services. Following the October 1991 settlement of the criminal and civil case against Exxon, the FWS joined with the DOI and other Federal and State agencies in planning the restoration of injured trustee resources. 
MINERALS MANAGEMENT SERVICE

While the MMS had no direct responsibility for response or damage assessment, the agency provided staff to assist the cleanup and monitoring efforts; an additional $\$ 300,000$ was directed to fund studies to assess the effects of the spill. MMS staff helped develop damage assessment programs, assisted in surveys and rehabilitation of seabirds and marine mammals, participated as members of a Resource Advisory Team, and provided technical expertise and assistance to the FWS and the Alaska Department of Fish and Game. Funding was provided for a study on the weathering of crude oil in seawater, for studies on the effects of oil on different species of fish and crustaceans, for surveys of sea otters and seabirds, and for collection of sediment samples for hydrocarbon analysis. In addition, support was provided for monitoring the performance of satellite-tracked surface oil drifters, for overflights of the spill, and for studies to determine the social impact of the spill on Native and non-Native communities adjacent to the spill's path. The MMS/ NOAA research vessel \#1273 was provided for use as a field sampling platform. Funding from the MMS National Studies Program enabled the USGS to deploy the Gloria Project survey ship M/V Farnella in 1989 and the smaller USGS-owned R/V Karluk in 1990 to collect bottomsediment samples.

The Social and Economic Studies Unit (SESU) of the Environmental Studies Section of the Alaska MMS OCS Region is presently involved in collecting information on the long-term social, economic, and cultural consequences of the Exxon Valdez oil spill for a number of communities in the Gulf of Alaska region. The SESU modified an existing contract, the Social Indicators Study, to allow the collection of information during calendar years 1989 through 1991. In addition, the SESU signed a cooperative agreement in 1991 with the Subsistence Division of the Alaska Department of Fish and Game to investigate the long-term subsistence and social consequences of the spill; this research is in progress.

\section{NATIONAL PARK SERVICE}

The Exxon Valdez oil spill impacted three national park units: Kenai Fjords National Park, Katmai National Park and Preserve, and Aniakchak National Monument and Preserve. In these park units, several hundred kilometers of shoreline, and the resources and services supported thereon, were affected by the oil and its cleanup. Although no cleanup operations were undertaken on NPS-managed lands in 1992, oil remained on park shorelines. An oilpersistence survey conducted by the NPS determined that small amounts of oil remained at more than 20 locations in these parks. In Katmai National Park and Preserve, the oil still had the appearance of fresh mousse and produced a sheen when disturbed.
Damage assessment activities by the NPS ended in late 1991 after the settlement was reached in the criminal oil-spill litigation against Exxon. State and Federal trustees secured combined settlement revenues totaling more than $\$ 1$ billion. In accord with the settlement agreement, the focus of governmental spill-related activities in 1992 changed from damage assessment to restoration of injured resources. The NPS provided DOI representation to four groups: (1) the Restoration Team, (2) the Public Participation working group, (3) the Habitat Protection working group, and (4) the Restoration Planning work group. The NPS also chaired the DOI interagency working group that prepared a prospectus for a subsistence injury study, and, in cooperation with NOAA, conducted a portion of the restoration study on oiled mussels.

Although the United States case against Exxon was settled, civil litigation by private plaintiffs is pending. During 1992 , over 200,000 pages of documents and records were reviewed and produced to litigants as a result of subpoenas filed in conjunction with these civil lawsuits.

\section{U.S. GEOLOGICAL SURVEY}

The USGS conducted four cruises in Prince William Sound between May 1989 and May 1992 to track oil from the spill. Samples from beaches, nearshore sediments, and deep-water sites were analyzed. At beach sites, visible contamination included sheens on water, thin coatings on rocks and sediments, brown mousse-like blobs, and tar (Kvenvolden and others, 1993). Both oily beach and shallow-water sediment samples showed chemical signatures similar to Exxon Valdez oil; the tar samples were chemically similar to California oil and may be remnant from a time when Alaska imported its oil. Only one-third of the 15 deep-water sites showed evidence of possible contamination.

Record low freshwater discharge from surrounding streams and glaciers may have limited the amount of Exxon Valdez oil that was incorporated into Prince William Sound sediments (Carlson and Kvenvolden, 1993). Oil must first bond to particulate matter in water before it can sink. In seasons of low runoff, low concentrations of particulate matter would preclude much spilled oil from being deposited in sediment basins. Spring 1989 was a lowrunoff season, and this may have been a contributing factor to the paucity of contamination in deep-water sites.

\section{COAL AND PEAT RESOURCES}

\section{OVERVIEW OF INDUSTRY ACTIVITY}

Estimated 1992 coal production for the United States was up 1.2 percent over 1991 levels, totaling 914.4 million metric tons (Coal News, January 25, 1993). In Alaska, 
however, coal production fell 0.6 percent to 1.39 million metric tons (table 6) (Swainbank and others, 1993). All commercial production came from the Usibelli coal mine at Healy in central Alaska (fig. 11). The Aluaq Mine, located at Deadfall Syncline on the western North Slope, extracted 680 metric tons on an exploration permit (Alaska Journal of Commerce, August 17, 1992). Other coal projects in Alaska are waiting for substantial growth in the energy needs of Alaska or Pacific Rim countries. When the time comes, the Alaskan coal industry will be ready to meet these increased demands.

The Alaska Mental Health Lands (AMHL) issue continues to plague the coal industry. The U.S. Congress created a 4,047-square-kilometer land trust in 1956 to provide funding for Alaska's mental-health programs; significant coal deposits in interior and south-central Alaska were included in the trust (Alaska Journal of Commerce, August 17, 1992). In fact, the trust generated very little revenue (Alaska Journal of Commerce, December 7, 1992) and was dissolved by the State legislature in 1978. Some of the lands were leased or sold to various government or private organizations. Mental-health advocates sued the State in 1982 to reconstitute the trust, and, in 1990, the Alaska Superior Court put on hold all State land conveyances, permits, and leases on trust lands. As a result, the Beluga and Wishbone Hill Mines (fig. 11) have been in hiatus for several years; production at Wishbone Hill was to have begun in 1992. By the end of 1992, the status of the AMHL litigation had still not been resolved.

Transportation costs are the single highest factor in determining the price of Alaskan coal. Coal from the Usibelli Mine cost about $\$ 3.60$ per metric ton more than other similar-quality coals in the Pacific Rim area, and approximately 60 percent of the price of coal delivered to Korea derives from transportation costs (Alaska Journal of Commerce, June 22, 1992). In 1992, officials for Usibelli, the Alaska Railroad, and Suneel Alaska agreed to lower coal prices by 9 percent, assuring a new contract with Suneel, a Korean utility (Fairbanks Daily News-Miner, August 10,1992). The agreement to lower prices was helped in part by a State pledge to lower royalties by 25 percent.

An economic feasibility study for coal-loading facilities at Port MacKenzie (fig. 11) is expected to get a green light from the Matanuska-Susitna Borough (Alaska Journal of Commerce, May 11, 1922). The size and types of facilities would depend on the volume of coal to be shipped. The deep-water Port MacKenzie could save \$2.75 to $\$ 4.50$ per metric ton of coal shipped to Pacific Rim countries (Anchorage Times, August 18, 1991), making Alaskan coal prices much more competitive in the world market.

The abundant coal resources on the North Slope (Stricker, 1991) continue to be attractive to the Arctic Slope Regional Corporation, which would like to develop its substantial holdings in the area. The proposed Aluaq coal mine (fig. 11) is located 145 kilometers north of the Red Dog zinc mine and produces 345 metric tons of coal per year for distribution to North Slope villages (Alaska Business Monthly, July 1992). Presently operating under an exploration permit, the mine expects to acquire an operating permit from the Alaska Department of Natural Resources (Alaska Journal of Commerce, August 24, 1992). Aluaq coal averages a heat value of 30.2 million joules per kilogram, moisture content of 4.6 percent, and low sulfur content of 0.25 percent (Alaska Journal of Commerce, May 18, 1992); the Deadfall Syncline contains 453.6 million metric tons of this coal (Alaska Journal of Commerce, August 3, 1992). Establishing a domestic market for Aluaq coal will speed the development of the mine; an operating coal mine, in turn, will attract the international market.

Diamond Alaska Coal Company and its subsidiary, Tidewater Services Corporation, are keeping open for another 5 years an option to lease Kenai Borough land for coal storage and handling (Anchorage Daily News, March 5, 1992). Diamond Alaska's Beluga coal mine is projected to be one of the 10 largest in the nation, but it is still years away from being developed. Much of the delay is directly attributable to the unresolved status of the AMHL trust. The Alaska State Supreme Court has also ruled that additional environmental permits are required for the mine access roads, airstrip, housing, and other facilities (Fairbanks Daily News-Miner, August 26, 1992); this ruling will probably add to development costs but not significantly delay production. No buyers for the coal are yet under contract.

The sale of power from the Healy Clean Coal Project to the Golden Valley Electric Association (GVEA) of Fairbanks has won approval from the Alaska Public Utilities Commission (Anchorage Daily News, September 5, 1992). The new \$215-million, 50-megawatt power plant will be located adjacent to GVEA's existing 25-megawatt power plant, 16 kilometers northeast of Denali National Park. The plant is part of a national program to demonstrate methods of burning coal without emitting pollutants such as sulfur dioxide and nitrogen oxides, the major contributors to acid rain. The plant will burn a $50-50$ blend of clean and waste coals; the fuel is to be supplied by the nearby Usibelli coal mine. The Fort Knox gold mine in Fairbanks will consume more than 70 percent of the new plant's planned output (Fairbanks Daily News-Miner, December 10, 1992). The Healy Clean Coal Project must still receive State and Federal environmental permits for its construction and operation.

Peat mined in Alaska is used primarily as a soil conditioner in commercial farming and greenhouses; minor amounts are burned locally in villages for heat. After 1991's large increase in peat production (table 6), 1992 production was smaller at 53,552 cubic meters, a decrease of 3,793 cubic meters (Swainbank and others, 


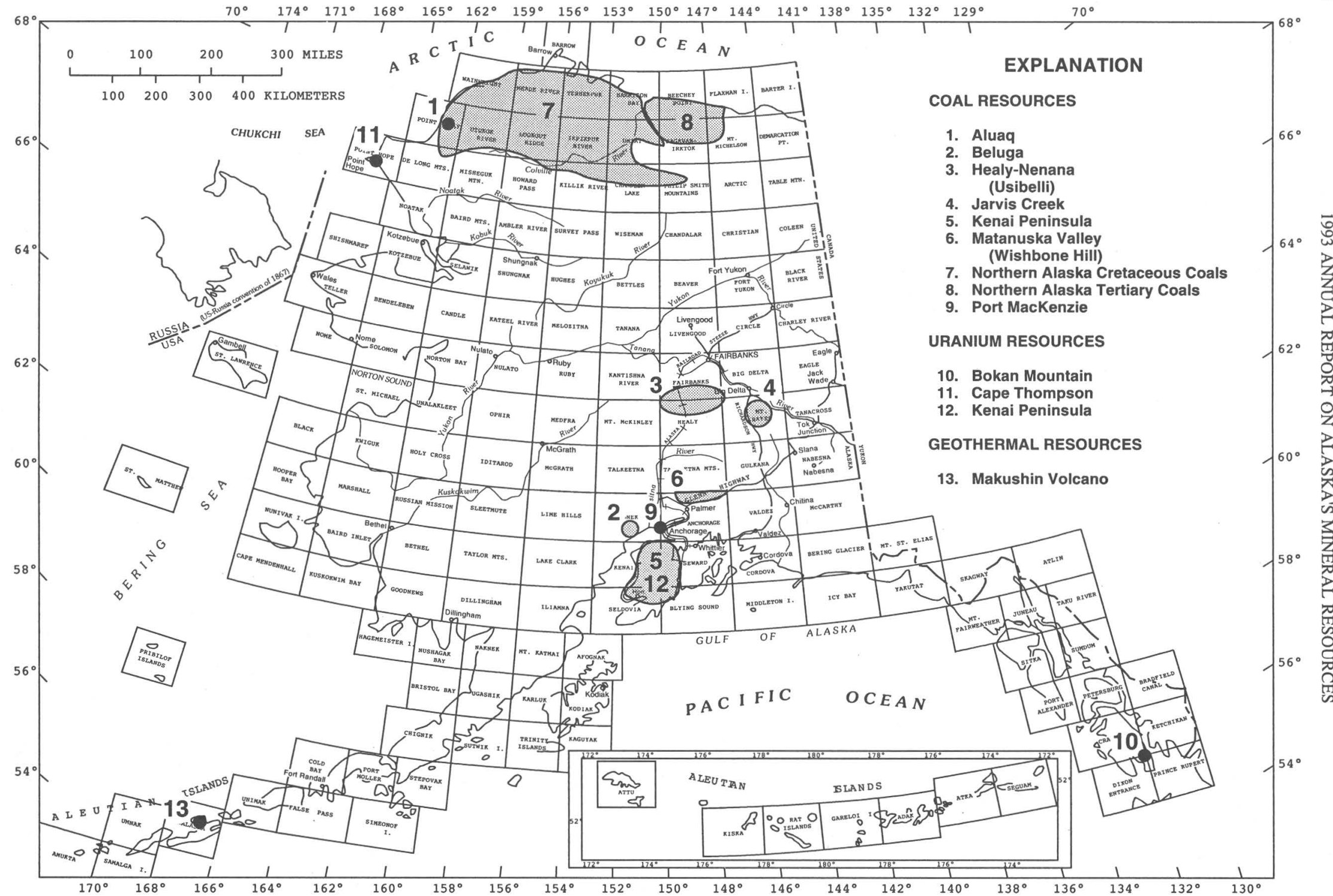

Figure 11. Areas of potential coal, uranium, and geothermal resources mentioned in text. 1:250,000-scale quadrangles are outlined and labeled. 
Table 6. Mining production in Alaska, 1989-1992

[Values calculated from 1992 annual price averages of gold, silver, platinum, zinc, and lead; other values directly supplied by mine operators. Data from Swainbank and others (1993). kg, kilogram; g, grams; NR, no report; W, information withheld by mine operators]

\begin{tabular}{|c|c|c|c|c|c|c|c|c|}
\hline & \multicolumn{4}{|c|}{ Volume } & \multicolumn{4}{|c|}{ Value $(\times \$ 1,000)$} \\
\hline & 1989 & 1990 & 1991 & 1992 & 1989 & 1990 & 1991 & 1992 \\
\hline Zinc (metric tons) ...................... & 18,007 & 164,350 & 252,346 & 248,978 & 29,383 & 253,680 & 278,221 & 301,958 \\
\hline Gold $(\mathrm{kg})$ & 8,852 & 7,206 & 7,585 & 8,163 & 108,724 & 89,204 & 88,292 & 88,463 \\
\hline Silver $(\mathrm{kg})$ & 162,102 & 315,199 & 281,382 & 283,500 & 27,361 & 50,675 & 39,114 & 34,913 \\
\hline Lead (metric tons) .................... & 8,689 & 40,106 & 63,119 & 62,278 & 7,672 & 30,954 & 33,404 & 31,585 \\
\hline Tin $(\mathrm{kg})$ & 87,988 & 25,855 & 3,084 & 680 & 672 & 200 & 22 & 6 \\
\hline Platinum $(\mathrm{g})$ & W & NR & 465 & $\mathrm{~W}$ & NR & NR & 5 & W \\
\hline $\begin{array}{l}\text { Sand and gravel .......................... } \\
\text { (million metric tons) }\end{array}$ & 13.1 & 13.6 & 12.8 & 13.2 & 39,875 & 40,822 & 45,449 & 42,200 \\
\hline $\begin{array}{l}\text { Building stone } \\
\text { (million metric tons) }\end{array}$ & 2.6 & 2.9 & 2.7 & 2.6 & 20,340 & 22,100 & 22,500 & 22,971 \\
\hline $\begin{array}{l}\text { Jade and soapstone } \\
\text { (metric tons) }\end{array}$ & 51.7 & W & 14.5 & 1.4 & 1,140 & $\mathrm{w}$ & 12 & 30 \\
\hline Coal (metric tons) ..................... & $1,317,574$ & $1,429,000$ & $1,396,780$ & $1,388,620$ & 41,465 & 44,990 & 39,000 & 38,300 \\
\hline Peat (cubic meters) .................. & 38,995 & 49,699 & 57,345 & 53,552 & 352 & 400 & 450 & 400 \\
\hline Totals & 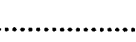 & 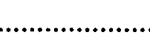 & . & . & 276,984 & 533,025 & 546,469 & 560,826 \\
\hline
\end{tabular}

1993). Alaska has one of the world's largest peat resources, estimated to be five times the energy potential of Prudhoe Bay.

\section{ACTIVITY BY FEDERAL AGENCIES}

\section{U.S. GEOLOGICAL SURVEY}

Branch of Coal Geology personnel investigated the coal-bearing Beluga and Sterling Formations of the Kenai Group during the summer of 1992. On the eastern shore of Cook Inlet, they measured 20 stratigraphic sections near Homer, 15 sections north of Ninilchik, and 30 sections at Clam Gulch; 45 sections were measured along the north flank of Wishbone Hill syncline in the Matanuska Valley (fig. 11). Papers detailing the results of the field studies are listed in appendix 1, USGS section (Flores and Stricker, 1993a, 1993b).

Investigations continue of the vertical and horizontal major-, minor-, and trace-element distribution in the coal beds of the Usibelli Mine near Healy. In 1992, 60 facechannel samples from the Number 3 seam and Number 6 seam were collected for chemical analyses. Previous work at the mine (Affolter and Stricker, 1987) indicated that many trace elements vary both vertically and horizontally within the three beds being mined. Subbituminous coals at Healy have some of the lowest reported sulfur values for any coal being mined in the United States, with a mean of 0.24 percent and a range of 0.1 to 1.5 percent total sulfur (Stricker, 1991).

\section{BUREAU OF LAND MANAGEMENT}

The BLM continued its management of a lease in the Jarvis Creek Coal Field south of Delta Junction (fig. 11) and awarded a permit to Hobbs Industries to conduct exploration activities on the lease. Coal from this field is a potential feedstock for gas production, which would be used to generate electrical power for the U.S. Army base at Fort Greeley. Interest in additional coal leasing on Federal land currently is growing.

The BLM has been assessing the coal potential of NPRA, in cooperation with the USBM and USGS, as part of the USBM Colville mining district study.

\section{DEPARTMENT OF ENERGY}

Plans for the new and innovative 50-megawatt, coalfired power plant at Healy have moved into the design and engineering phase. Using advanced combustion and fluegas-cleanup technologies, the plant is intended to demonstrate the combined removal from stack emissions of particulate matter and the nitrogen-oxide compounds and sulfur dioxide that contribute to acid rain. Proposed construction is sited adjacent to the existing GVEA's Healy Unit 1 . The plant is being financed by a $\$ 104$-million Clean Coal Technology cooperative agreement monitored by the DOE's Pittsburgh Energy Technology Center; the agreement was awarded on April 11, 1991. A consortium headed by the Alaska Industrial Development and Export Authority (AIDEA) will provide the remaining $\$ 111$ million for the project's completion. 
The Alaska Public Utilities Commission gave its approval to the Healy Clean Coal Project on September 3, 1992, and recommended that AIDEA be granted the "certificate of public convenience and necessity" needed for the project to move forward. The commission also approved a power sales agreement between the AIDEA and the GVEA, the new plant's operator and primary customer.

A draft environmental impact statement (EIS) was prepared for the project by the DOE in November, 1992 (Pittsburgh Energy Technology Center, 1992). Hearings to receive comments on the Draft EIS were held in December, 1992, in Healy, Fairbanks, and Anchorage.

The DOE funding for this power plant is part of a national program to demonstrate the new and clean methods of burning coal while limiting the emission of pollutants commonly cited as the causes of acid rain.

\section{URANIUM RESOURCES}

\section{OVERVIEW OF INDUSTRY}

In 1992, the U.S. uranium mining industry experienced another poor year and continued to operate at a reduced level. The U.S. Secretary of Energy declared the domestic uranium industry to be nonviable for the eighth straight year. Domestic production of uranium concentrate $\left(\mathrm{U}_{3} \mathrm{O}_{8}\right)$ was down from 3,629 metric tons in 1991 to 2,268 metric tons in 1992 (W.L. Chenowith, oral communication, 1993); domestic use of uranium increased slightly in 1992 to about 39.5 million metric tons (Pool, 1992). At the beginning of 1992, the spot price of $\mathrm{U}_{3} \mathrm{O}_{8}$ was $\$ 3.97$ per kilogram and averaged $\$ 4.54$ per kilogram for uranium received under contract to domestic utilities (Chenowith, 1992). Uranium dumped on the market by countries in the Commonwealth of Independent States depressed uranium prices worldwide.

No uranium has been produced in Alaska since the Ross-Adams Mine on Bokan Mountain (fig. 11) closed in 1971 (Warner and Barker, 1989). Uranium is still produced in the conterminous U.S. but only by recovery from inactive underground mine waters, by solution mining, and as a byproduct of phosphoric acid production; uranium is no longer produced from conventional mines or milled at conventional mills. The last open-pit uranium mine in the United States, Pathfinder's Shirley Basin Mine in Wyoming, closed on March 31, 1992, and the associated mill was closed after processing of the stockpiled ore was completed (Odell, 1992).

\section{ACTIVITY BY FEDERAL AGENCIES}

\section{U.S. GEOLOGICAL SURVEY}

A core program in uranium research continues to be carried out by the USGS in the Branch of Sedimentary
Processes, but the emphasis has shifted toward the study of uranium and other radionuclides as environmental hazards and away from uranium as an energy source. The uranium research program was originally designed to keep the United States abreast of uranium geology research and to maintain the capability to carry out such work. The only remaining Alaskan research is based on previously collected data or is ancillary to other studies. A paper describing uranium distribution and its relation to sediment sources in the Kenai Group on the Kenai Peninsula (fig. 11) was released in 1992 (Dickinson and Skipp, 1992). This report is listed in appendix 1, USGS section.

\section{U.S. FISH AND WILDLIFE SERVICE}

In response to public concern over radioactive soils buried in the tundra at Cape Thompson, the FWS, ACE, DOE, and State authorities investigated the site north of Kotzebue (fig. 11). The contaminated soils resulted in 1962 from research to evaluate potential effects on local water supplies of Project Chariot, the proposed peacetime use of a nuclear device to blast a deep-water harbor east of Point Hope. The explosion would have released radioactive particles into the environment; therefore, an experiment was conducted to evaluate how the particles would move when deposited on the tundra. Acting on behalf of the U.S. Atomic Energy Commission, USGS scientists obtained mixed fission products and measured amounts of three specific radioisotopes totaling 26 millicuries of radioactive material, diluted them in sand and soil, and applied the mixture to 10 test plots (Piper, 1966, p. 18-22). Following experiments, the test plots were dug up, mixed with additional soil, and buried in a trench that had been bulldozed down to permafrost; 4 feet of clean soil covered the trench. After burial, there was no detectable radiation above background levels both at the surface of the burial site and at each of the test plots. The USGS estimated that the amount of radioactive material remaining at the site to be no more than 3-5 millicuries and probably less than 2 millicuries. In 1992, the FWS posted the burial site with signs: "Warning-Radioactive materials have been found on refuge lands behind this sign-Do not enter." The Alaska Department of Health and Social Services concluded that the radioisotopes buried at the site present no health risk to persons in the area and recommended that the soils not be removed (Chandler and Middaugh, 1992). However, the DOE has asked the FWS to prepare an environmental analysis addressing the soils' removal.

\section{GEOTHERMAL RESOURCES}

Hot springs occur throughout Alaska and historically have been used on a small, highly localized scale for recreation, space heating, and agriculture. However, widespread 
young volcanic activity on the Aleutian Islands, the Alaska Peninsula, the Wrangell Mountains, and elsewhere in the State has created the potential for commercial geothermal energy production to serve selected population centers. The Alaska Energy Authority has targeted Makushin Volcano (fig. 11) as a potential source of power for the neighboring communities of Dutch Harbor and Unalaska, centers of the fishing industry in the northwestern Pacific Ocean.

No Federal research was funded for geothermal studies in Alaska in 1992.

\section{NONFUEL-MINERAL RESOURCES}

\section{METALLIC MINERALS}

The locations of mineral deposits, mines, and areas discussed in the following review of 1992 industry activity are shown on figure 12 .

\section{ECONOMIC OVERVIEW}

The value of Alaska's mineral industry, measured by the sum of exploration and development expenditures and the value of mineral production, has increased steadily since 1989. In 1992, the value of production of coal, peat, metals, and industrial minerals rose three percent to $\$ 560.8$ million (table 6) (Swainbank and others, 1993), mainly on the strength of zinc prices and concurrent output from the Greens Creek and Red Dog Mines. However, most metal commodity prices remained low and affected the profitability of many Alaskan mines; five gold placers ceased production in 1992, and Greens Creek announced its closure in February 1993. Mineral development expenditures also increased in 1992 , rising 16 percent to $\$ 29.6$ million; most of the increase was due to work at the Fort Knox deposit near Fairbanks and the Greens Creek Mine near Juneau (Swainbank and others, 1993). As many projects moved into their development stage, exploration expenditures dropped 24 percent to $\$ 30.4$ million (Swainbank and others, 1993); this is the second consecutive year for reduced exploration monies in Alaska.

For the third straight year, zinc was the most valuable ore commodity in Alaska, making up 66 percent of the 1992 production value. Together, the Greens Creek and Red Dog Mines produced about half of the total domestic zinc, 12 percent of the lead, and 17 percent of the silver (Swainbank and others, 1993). Gold production in Alaska increased 7 percent, but lower prices in 1992 kept production values static. Silver production also increased, but depressed prices decreased its value. Tin production in Alaska has become negligible since the Lost River tin mine on the Seward Peninsula closed in 1989.

The staking of new claims and maintenance of current claims have plummetted since 1988 (table 7). Preliminary estimates by the Alaska Division of Mining show that 2,501 new State claims and 679 new Federal claims were recorded in 1992 (Swainbank and others, 1993); this represents a drop of 69 percent for State claims, and 82 percent for Federal claims, in the span of 5 years. Active claims total 29,116 State and 20,933 Federal, a decrease of 13 percent from 1991's total of 57,666 State and Federal claims.

Alaska's mining industry employed 3,492 people in 1992 (Swainbank and others, 1993). Echo Bay Mines is developing two projects near Juneau that are expected to create 850 new jobs, and the development of the Fort Knox Mine near Fairbanks could result in an additional 200 to 250 jobs. The State's traditional placer-mining industry (fig. 13) is composed of 200 small- to mediumsized placer mines that result in an economic output of 1,251 jobs and $\$ 79$ million in expenditures, for a total economic contribution of $\$ 230$ million (Alaska Journal of Commerce, October 19, 1992). Two hundred small to medium-small mines produced over 6 million grams of gold in 1991, approximately 2.5 percent of total domestic production. The Red Dog Mine in northwestern Alaska employs 280 people and is projected to return $\$ 900$ million to the State's economy over the estimated 50-year life of the project.

\section{PRECIOUS METALS}

AMAX Gold Incorporated has bought the Fort Knox gold deposit in central Alaska from Fairbanks Gold Limited, in a stock-swap merger valued at $\$ 200$ million; the deposit is located about 24 kilometers northeast of Fairbanks and is expected to become the largest goldproducing mine in North America (Anchorage Times, January 7, 1992). AMAX plans to spend $\$ 220$ million over the next 3 years to develop Alaska's first low-grade gold mine. Fort Knox contains 99.5 million grams of proven reserves and should yield approximately 10.9 million grams of gold annually (Anchorage Times, January 29, 1992). The mine is expected to employ 200 to 250 people, processing approximately 32,600 metric tons of ore per day for 10 years at an extraction cost of $\$ 6.43$ to $\$ 6.91$ per gram, which would add $\$ 60$ to $\$ 70$ million to the local economy (Anchorage Times, March 7, 1992). Forty government permits are needed to bring the mine into operation, and production is expected by 1995 (Alaska Miner, 1992).

Adjacent to the Fort Knox project, the 130-squarekilometer Golden Summit property is under development. FreeGold Recovery has completed 13 trenches for 1,680 meters at the Too Much Gold and McNeil prospects. All trenches have been mapped, and preliminary results showed 72 meters in Trench 6 averaging 1.5 grams of gold per metric ton. FreeGold Recovery also began a 1520meter reverse-circulation drilling program at the Too Much Gold Prospect to evaluate mineralization that extends over 


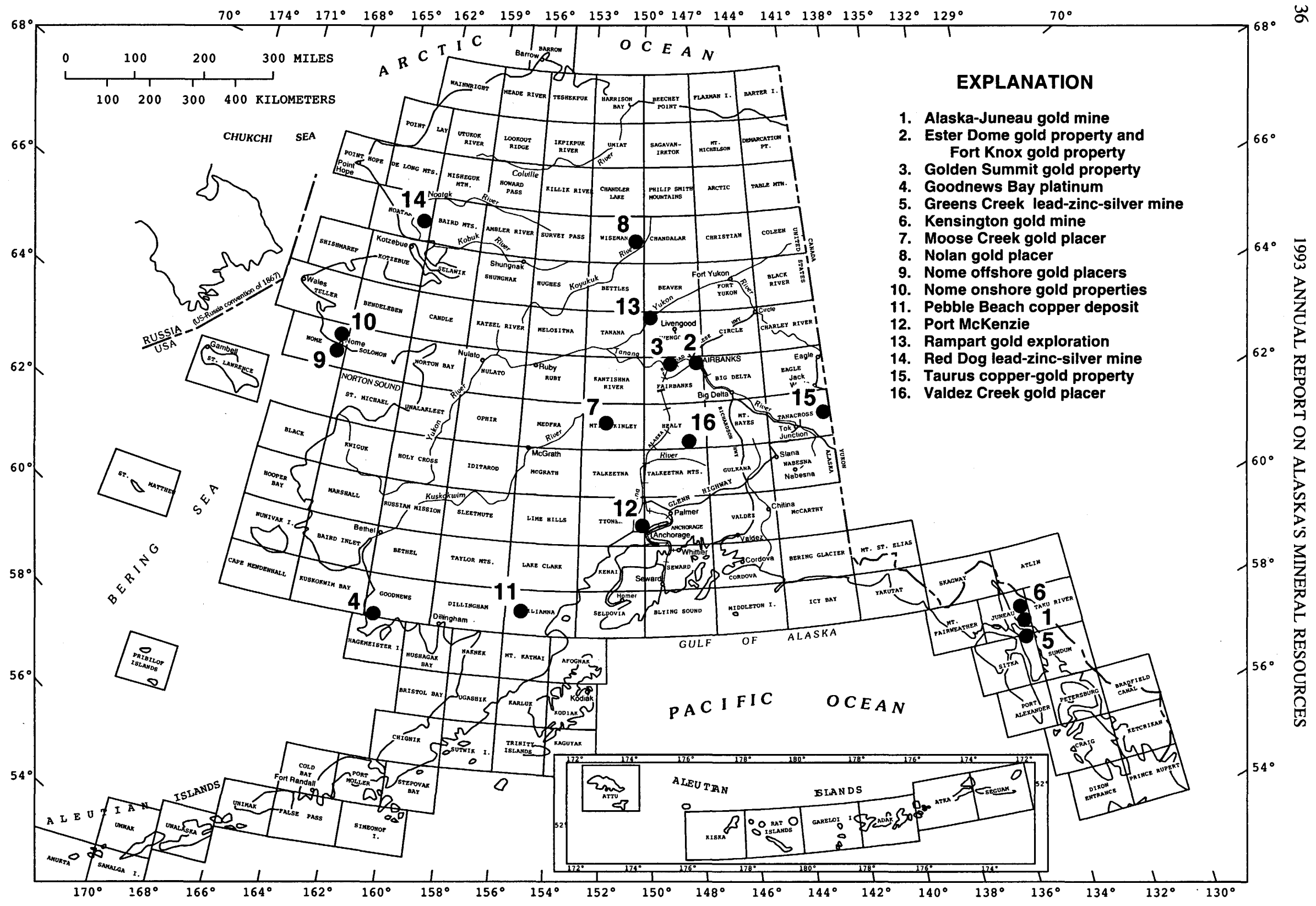

Figure 12. Areas of significant industry activity involving metallic minerals (excluding uranium) in 1992, and mine and deposit locations referred to in text. 1:250,000-scale quadrangles are outlined and labeled. 
Table 7. Mining claims in Alaska, 1988-1992

[Data from Alaska Division of Geological and Geophysical Surveys. N/A, not available]

\begin{tabular}{|c|c|c|c|c|c|c|c|}
\hline \multirow{2}{*}{ Year } & \multicolumn{3}{|c|}{ Federal claims } & \multicolumn{3}{|c|}{ State claims } & \multirow{2}{*}{$\begin{array}{c}\text { Total } \\
\text { active } \\
\text { claims }\end{array}$} \\
\hline & New & Existing & Total & New & Existing & Total & \\
\hline 1988 & 3,786 & N/A & N/A & 8,062 & N/A & N/A & 75,542 \\
\hline 1989 & 1,562 & N/A & N/A & 3,928 & N/A & N/A & 69,613 \\
\hline 1990 & 1,888 & 30,173 & 32,061 & 2,573 & 27,894 & 30,467 & 62,528 \\
\hline 1991 & 1,299 & 25,745 & 27,044 & 3,391 & 27,231 & 30,622 & 57,666 \\
\hline 1992 & 679 & 20,254 & 20,933 & 2,501 & 26,615 & 29,116 & 50,049 \\
\hline
\end{tabular}

a 760-meter strike and is open in all directions (Mining Journal, September 11, 1992). A \$200,000 exploration program is being planned for the Newsboy claim block. Before 1942, Golden Summit reportedly produced approximately 1.2 million grams of gold and 0.62 million grams of broken ore from a 107-meter deep shaft (Northern Miner, March 16, 1992).

Gold properties at Ester Dome are also being developed. Gold reserves are estimated at 43.5 million grams in low-grade disseminated mineralization over an 11-kilometer trend. Silverado Mines Limited confirmed three zones with a total of 12.3 million grams of gold (Anchorage Times, January 30, 1992); the company has spent $\$ 21$ million over the past 12 years evaluating Ester Dome (Fairbanks Daily News-Miner, January 30, 1992). In a joint venture with American Copper and Nickel Company, Silverado is exploring 15 deposits in the area. The companies plan to spend $\$ 2.8$ million over the next two years to explore their joint ventures.

Citigold Alaska, Incorporated hopes to open its Ryan Lode gold mine on Ester Dome by the summer of 1993. After exploration in 1992, the company increased its

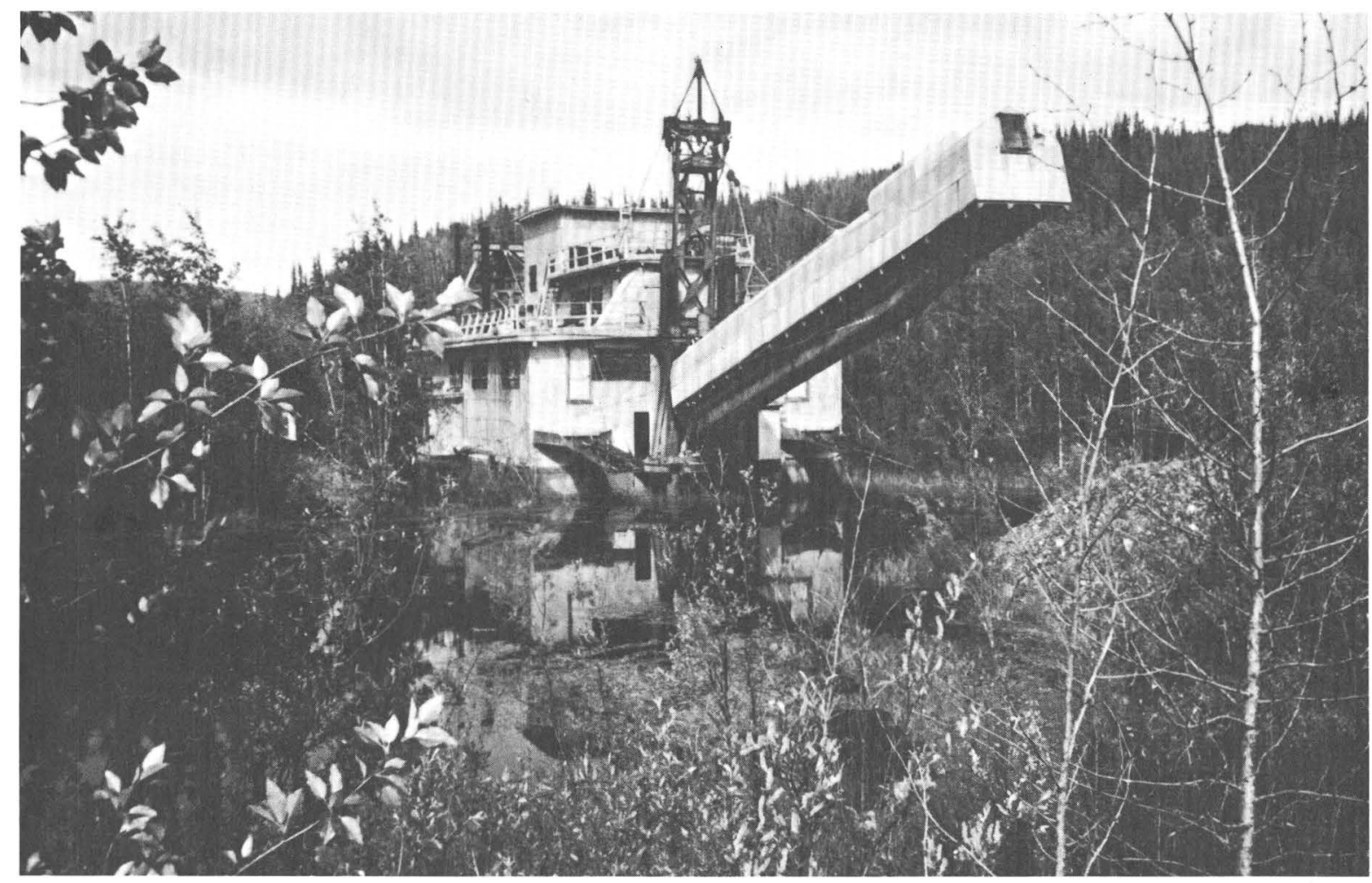

Figure 13. Gold-placer dredge in Chicken Creek, Fortymile mining district, southeastern Eagle quadrangle, which operated between 1959 and 1967. Gold mining has been active in the district since 1886, when gold was discovered on Franklin Bar in the Fortymile River. Photograph by W. Yeend. 
estimated reserves from 9 million to 17 million grams of gold, with an average grade of 2.5 grams per metric ton $(\mathrm{g} /$ t) of ore. A closed milling system for gold recovery, as opposed to heap-leaching operations, would process 270 to 450 metric tons of ore per day, with the capacity to increase to 900 metric tons per day (Fairbanks Daily NewsMiner, September 14, 1992).

Silverado announced the discovery of a high-grade ore zone from the Nolan placer gold mine, 290 kilometers north of Fairbanks. Ten gold nuggets totaling 249 grams were recovered from a 0.6 -meter-thick pay streak known as the Thompson Pup. Analysis of 0.01 cubic meters of material showed 1.6 grams of gold per cubic meter (Alaska Journal of Commerce, September 28, 1992). In 1993, production will shift to the Wooll Bench area of the claim, which has an indicated potential of 2.5 million grams of gold. Exploration and development have taken 10 years; the mine is expected to produce a cash flow of $\$ 10,000$ to $\$ 30,000$ per week (Anchorage Times, May 23 , 1992).

Montague Gold has announced several gold anomalies on the Rampart joint venture 130 kilometers west of Fairbanks. Soil sampling has returned grades up to $2.8 \mathrm{~g} / \mathrm{t}$ gold. Quartz-arsenopyrite veins and veined monzonite have also been found to contain gold (Mining Journal, October 16, 1992).

In south-central Alaska, Cambior Mines operates the Valdez Creek Mine and anticipates its best year yet in gold production with an expected output of 2.7 million grams of gold. The mine has enough reserves for 10 to 11 years of production. Valdez Creek began operating in 1984 with a \$45-million capital investment. The company averages $\$ 20$ million yearly in direct operating expenditures, almost all of it with Alaska vendors. This year, payroll will total nearly $\$ 9$ million (Alaska Journal of Commerce, October 12, 1992). Caprock Corporation awarded a contract to American Independent Mining to carry out all development and mining operations for its Valdez Creek placer gold property near the Cambior Mine. Production should start July 1, 1993, and yield 155,500 grams of gold per year. Proven geologic reserves total 2.7 million grams, with 1 million grams probable and 2 million grams possible. The company has identified gold over a 6-kilometer stretch of river (Mining Journal, June 19, 1992).

Montague Gold has contracted with Doyon Limited, an Alaskan Native regional corporation, to explore mineral prospects on Doyon lands in central Alaska. At least 10 separate types of known or potential mineral deposits are represented within the area (Mining Journal, January 17, 1992). Of the 26 exploration blocks, Montague Gold will earn 50-percent interest on the blocks held by ASA Incorporated, which has an option to acquire 100 percent of the land from Doyon in exchange for its exploration expenditures and 3-percent production royalty. Doyon Limited holds surface title and mineral rights to 50,000 square kilo- meters. Montague had to repay ASA's past exploration costs of $\$ 460,500$ and commit $\$ 1.9$ million towards exploration in both 1992 and 1993 (Mining Journal, February 14, 1992).

In west-central Alaska, Newmont Mining Corporation, Aspen Exploration Corporation, and Golden Glacier Incorporated have formed the Anvil joint venture to explore and develop the Anvil Creek lode-gold deposit (Mining Journal, April 24, 1992). Exploration could take up to 5 years in an area containing at least 15.5 million grams of gold. Hawley Resource Group announced that it will assess an area north of Nome for gold and other minerals (Anchorage Daily News, April 14, 1992). Alaska Gold Company announced it will begin year-round operations at its openpit mine near Nome in an effort to boost profits (Fairbanks Daily News-Miner, October 23, 1992). The Alaska Department of Transportation funded a $\$ 40,000$ study of a 7.2kilometer-long road to link potential gold-mining areas near Nome to an existing highway. The proposed road would connect the Glacier Creek Road with the NomeTeller Highway at an estimated cost of $\$ 2.6$ million (Anchorage Times, May 13, 1992). At least $\$ 10$ million has been pledged by mining companies for the roadwork (Alaska Journal of Commerce, May 18, 1992).

In southeastern Alaska, intense interest in the Juneau gold belt continues. Echo Bay Mines Limited has acquired the remaining 15-percent working interest in the A-J gold mine and is working to reopen the mine. Total reserves approach 90.7 million metric tons of ore grading 1.75 grams of gold per metric ton (Swainbank and others, 1993). The A-J Mine was the largest gold mine in North America in the 1930's and early 1940's, producing more than 105.7 million grams of gold from 1886 to 1944 (fig. 14). In addition, the Treadwell Mine, located directly across Gastineau Channel, produced more than 93 million grams of gold between 1882 and 1917, when the mine workings were flooded by the sea. Echo Bay plans to sell $\$ 100$ million in new stock to help finance a large-volume underground mine and mill, able to produce 20,412 metric tons of ore per day that would yield 1.15 million grams of gold per year (Anchorage Times, January 28, 1992). Nearly two dozen Federal, State, and city permits are needed to operate the mine, build tailings dams, and discharge waste water into Gastineau Channel.

Echo Bay and Coeur Alaska, Incorporated have joined to develop the Kensington gold property north of Juneau. With ore reserves of 10.4 million metric tons grading 4.9 grams gold per metric ton, production from the mine is planned for 3,600 metric tons of ore per day, yielding 6.2 million grams of gold per year (Wells, 1992). The venture requires about 50 Federal, State, and city permits. A coalition of 12 environmental, fishing, and Native groups called for the elimination of the proposed Lynn Canal mixing zone for mine waste water (Anchorage Daily News, January 23, 1992). The USFS completed its final environ- 
mental review of the proposed mine, recommending tougher waste-water treatment methods and relocation of the waste-water drain pipe (Anchorage Times, February 12, 1992). The USFS released the mine's Final EIS in the spring of 1992; the EIS will be reviewed further by the EPA, ACE, and the City and Borough of Juneau (Fairbanks Daily News-Miner, August 2, 1992). The Juneau Planning Commission authorized enforcement action against the Kensington Mine if the operation does not meet State and Federal waste-water discharge standards (Anchorage Daily News, September, 26, 1992) and approved the mine's conditional-use permit in October 1992 (Swainbank and others, 1993).

Juneau has annexed 360 square kilometers on Admiralty Island to bring the Greens Creek silver-lead-zinc mine under its jurisdiction, effective January 1, 1994. The Greens Creek property is valued at $\$ 62$ million (Anchorage Times, March 6, 1992). However, Kennecott announced in February 1993 that the mine would close in April of that year for an indefinite period of time and that

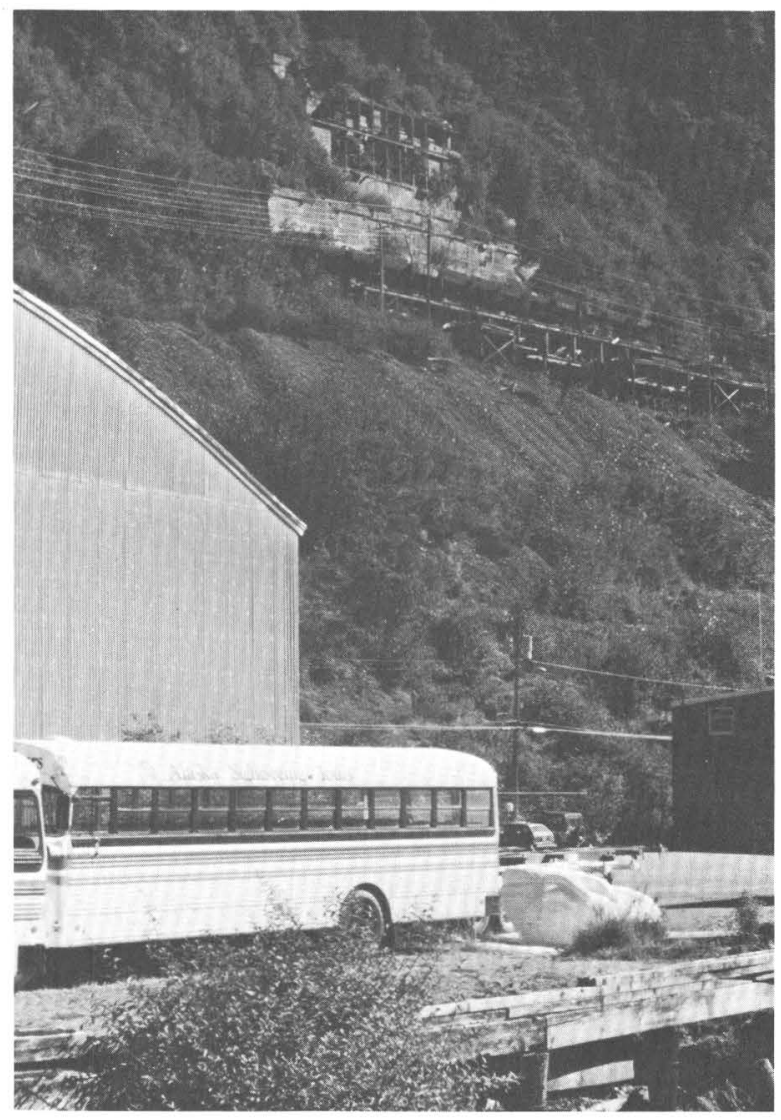

Figure 14. Abandoned workings of the Alaska-Juneau (A-J) Mine on hillside above downtown Juneau in southeastern Alaska. Echo Bay Mines is currently working through the permitting process preparatory to reopening the mine. Photograph by R. Griffin. the workforce of 230 people would be dismissed. The company ascribed the closure to depressed metals prices (Fairbanks Daily News-Miner, February 17, 1993). The final cost of development of the mine is estimated to have been $\$ 106$ million, and the annual payroll about \$17 million.

\section{OTHER METALS}

In east-central Alaska, Lodestar Exploration is investigating the Taurus copper-gold-molybdenum property, located 48 kilometers from Tok. A 2,000-meter drilling program will focus on the East Taurus zone, one of two large mineralized areas outlined on the 120 -square-kilometer property; this zone is reported to contain reserves of 127 million metric tons grading better than 0.03 percent molybdenum and 0.28 grams gold per metric ton (Northern Miner, March 9, 1992). Previous explorations have intersected a 268 -meter zone grading 0.32 percent copper, a 46-meter zone of 0.4 percent copper, and a 125 -meter zone of 0.22 percent copper with 0.45 grams gold per metric ton gold (Northern Miner, May 4, 1992). A recent letter of agreement allows Helmo Gold Mines to earn 50 percent interest in the Taurus property.

Several companies in a joint venture will spend $\$ 4$ million over the next two years exploring for gold, silver, lead, and zinc in east-central Alaska. This Stone Boy venture will cover 15,700 square kilometers near Fairbanks (Northern Miner, October 12, 1992).

In south-central Alaska, Midrex Corporation is considering a site near the proposed deep-water Port MacKenzie for a multi-million-dollar direct-reduced iron plant. The firm was attracted to the area by the potential source and attractive price of natural gas, plus the potential development of Port MacKenzie (Alaska Journal of Commerce, August 3, 1992).

In southwestern Alaska, Platinum Limited of Colorado has leased 210 square kilometers of Calista Corporation land in Goodnews Bay. Calista is the second largest of the 13 regional Native corporations, with land holdings of 26,300 square kilometers. Platinum placer mining began in Goodnews Bay in 1928; for decades, this area was the only producer of the metal in the United States. A reported 20 million grams of platinum were recovered from Goodnews Bay placers. Alaska Platinum is concentrating its efforts around Red Mountain, thought to be the lode source for the placer platinum; the company estimates a 77 -million-gram resource worth $\$ 1$ billion (Mining Journal, July 24, 1992).

In the Bristol Bay region, Cominco's drilling program at the Pebble Beach copper deposit more than doubled the preliminary reserve estimates. Based on 12,000 meters of drilling in 82 holes, estimates now total 450 million metric tons of ore grading 0.35 percent copper with 0.4 grams gold per metric ton (Northern Miner, March 9, 1992), worth about $\$ 2.6$ billion. However, due to its remote 
location about 27 kilometers northwest of Lake Iliamna, the project requires extensive and costly infrastructure in the form of roads and electrical installations. Thus, the project's marginal economics, caused by a combination of low ore grades, depressed metals prices, and remote location, have caused the company to postpone development of the deposit until worldwide metal prices improve (Anchorage Daily News, July 16, 1992).

\section{ACTIVITY BY FEDERAL AGENCIES}

\section{U.S. GEOLOGICAL SURVEY}

Locations of USGS studies carried out during 1992 are shown on figures 15 and 16.

\section{ALASKA MINERAL RESOURCE ASSESSMENT PROGRAM}

AMRAP studies are conducted at four progressively more detailed levels to produce comprehensive assessments of the mineral and energy resources of Alaska. Level I studies are statewide in scope, and published maps are generally at a scale of 1:2,500,000. No level I studies are being pursued at this time.

Level II studies address large parts of the State, and resultant maps are generally published at a scale of $1: 1,000,000$. Level II studies of geology and mineral resources are ongoing on the Alaska Peninsula and in the eastern Alaska Range.

Level III studies consist of multidisciplinary evaluations involving team studies of selected 1:250,000-scale quadrangles; these continue to be the primary focus of AMRAP. Areal assessments are based on the integration of geologic, geochemical, and geophysical data to estimate the probability of occurrence of certain mineral resources within delineated tracts of geologic favorability. Favorability is ranked as low, medium, or high, based on an evaluation of geologic features and attributes present within each tract. Although numerous projects have been recessed or scaled down due to the lack of funding, level III studies are in progress in 26 quadrangles. Field work is complete, and reports are in preparation or in press, for the Baird Mountains, Bendeleben/Solomon, Bethel, Chandler Lake, Craig/Dixon Entrance, Goodnews Bay/Hagemeister Island, Gulkana, Iditarod, Killik River, Lime Hills, Livengood, Port Moller/Stepovak Bay/Simeonof Islands, and Survey Pass quadrangles. Field work will continue in the Atlin/Juneau/Skagway/Taku River, Howard Pass, Seldovia, Sitka, and Sleetmute quadrangles. To date, level III AMRAP assessments have been completed for 31 quadrangles (fig. 15). There now have been approximately 715 reports published under AMRAP.

Level IV studies consist of detailed mapping (1:63,360 or larger scale) and sampling of individual mineral deposits or mining districts, and related research. Ongoing level IV activities in Alaska include metamorphic and structural studies in the central and western Brooks Range, a study of lode-gold veins on the Seward Peninsula, geochemical studies of massive sulfide deposits in mafic volcanic rocks of the Chugach and Prince William terranes, and site-specific discussions of the Jualin, Kensington, and Greens Creek Mines in southeastern Alaska (fig. 16, table 8).

A discussion of the decision points and strategies involved in the quantitative assessment of undiscovered mineral resources was published in 1992 (Brew, 1992) In addition, the procedure that was used to quantitatively assess the undiscovered mineral resources of the Tongass National Forest was presented at an international workshop on mineral potential (Brew and others, 1992).

The mineral-resource assessment of the Bendeleben and Solomon quadrangles on the Seward Peninsula allowed the identification of 30 tracts that are favorable for the occurrence of 15 types of mineral deposits: low-sulfide gold-quartz veins, sediment-hosted zinc-lead deposits, Besshi massive sulfide deposits, tin veins, tin greisens, tin skarns, tin replacements, tungsten skarns, iron skarns, copper skarns, gold-bearing skarns, polymetallic veins, polymetallic-replacement deposits, zinc-lead-silver skarns, and low-fluorine stockwork molybdenum systems (Gamble and Till, 1993). Low-sulfide gold-quartz veins are the most common deposit type in the two quadrangles; fourteen tracts containing these veins, chiefly of moderate to high favorability, are delineated. Geologic mapping showed that these veins are restricted to the Nome Group and appear to have a particularly strong spatial correlation with certain lithologic subunits (Till and others, 1986).

A USGS team produced the first level III preliminary mineral assessment, geologic map, and geophysical maps ever compiled for the Holy Cross quadrangle in southwestern Alaska (Csejtey and Keith, 1992). The occurrence of five types of metallic-mineral deposit is considered possible, with areas of occurrence outlined for each: (1) epithermal mercury-stibnite vein deposits, (2) gold-tungsten vein deposits, (3) copper-zinc and chromium-coppernickel-platinum deposits, (4) copper-silver-tin polymetallic vein deposits, and (5) skarn deposits.

The "Metamorphic History of Alaska" has been published (Dusel-Bacon, 1991). It is the only comprehensive exposition of regional metamorphism in Alaska and has the following important applications to mineral-resource assessment and exploration: (1) identification of metamorphic protoliths to facilitate the determination of permissive terranes for various mineral deposit types; (2) delineation of low-angle faults, which often host gold mineralization; (3) location of possible source rocks for placer titanium deposits; (4) delineation of metamorphosed volcanosedimentary units that often host low-sulfide gold-quartz veins; (5) age and grade of regional metamorphism, which provide constraints on the timing and degree of fluid movement during metamorphism; and (6) identification of areas where ore deposits may have been mobilized and 


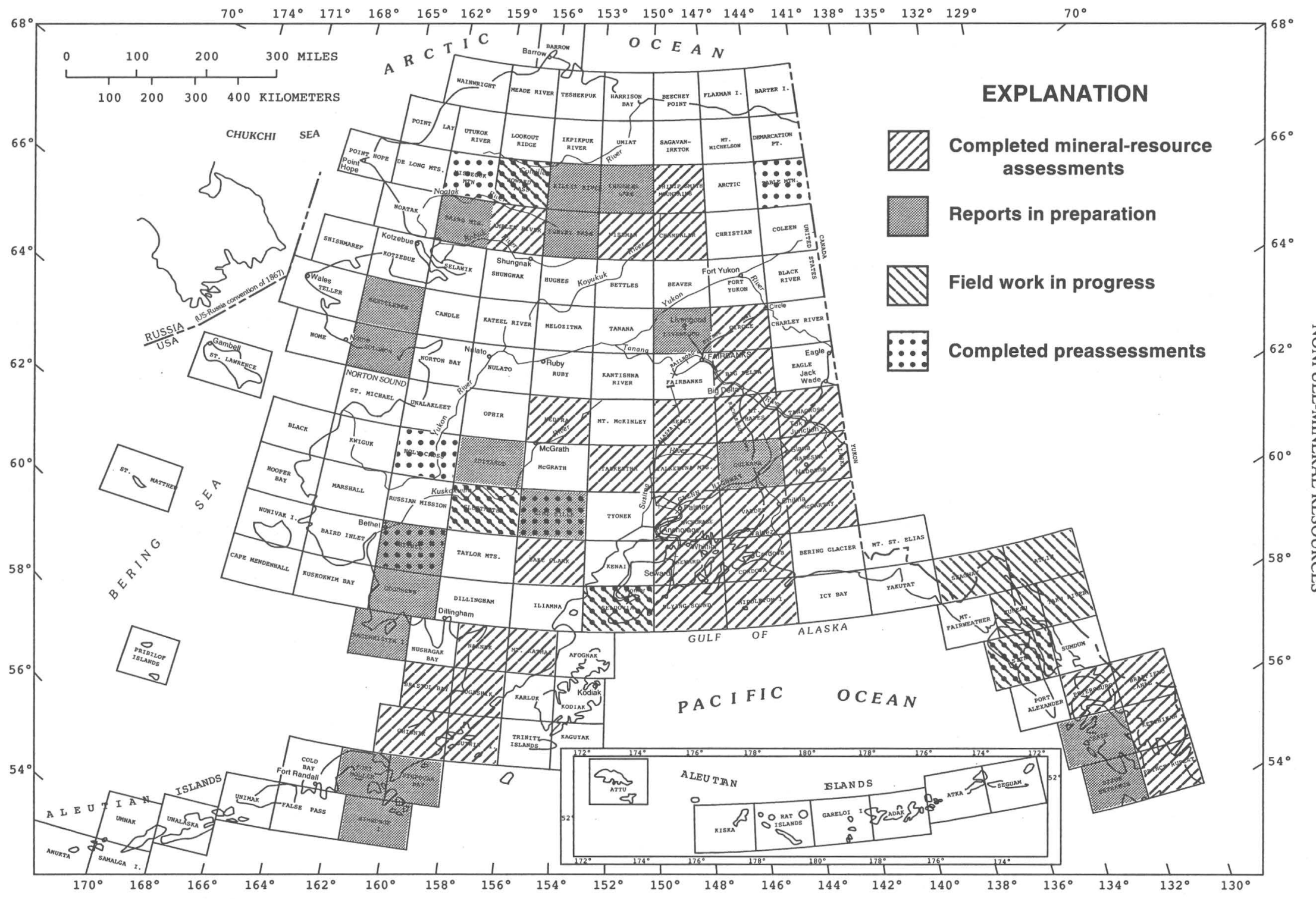

Figure 15. Status of USGS level III AMRAP quadrangle studies as of January 1993. 1:250,000-scale quadrangles are outlined and labeled. 


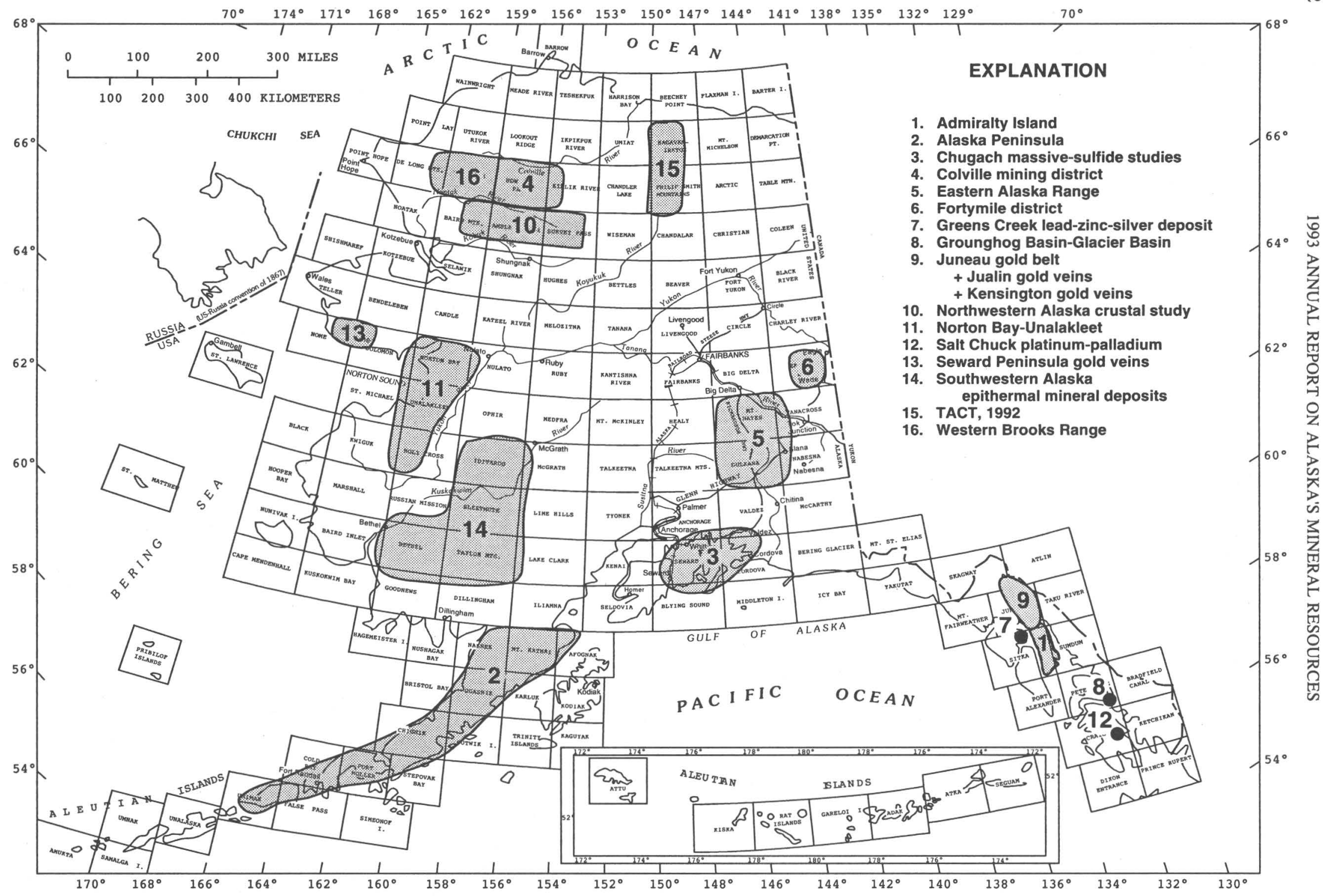

Figure 16. Locations of USGS level IV AMRAP metallic-mineral and TACT studies in 1992. 1:250,000-scale quadrangles are outlined and labeled. 
recrystallized during metamorphism, ensuring that ore minerals are sufficiently coarse grained to be separated during the milling process.

The annual report on USGS field and laboratory studies of mineral and energy resources and the geology of Alaska has been issued for 1991 (Bradley and DuselBacon, 1992). Mineral-resource studies in this publication are listed in appendix 1, USGS section, and include reports on exploration geochemistry in the Howard Pass quadrangle (Kelley, Borden, and others, 1992), Iditarod quadrangle (Gray, Hageman, and Ryder, 1992), and Admiralty Island (Taylor, Cieutat, and Miller, 1992); a mineralresource assessment of the Bethel quadrangle (Frost, Box, and Moll-Stalcup, 1992); a fluid-inclusion study in the Nome Gold District (Apodaca, 1992); geochemistry of lode-gold deposits in the Seldovia quadrangle (Borden and others, 1992); a new occurrence of placer gold in the Seldovia quadrangle (Cieutat and others, 1992); gold in coal in the Healy quadrangle (Stricker and others, 1992); experimental abrasion of detrital gold (Yeend, 1992); and a new occurrence of rare-earth minerals in southeastern Alaska (Philpotts and Evans, 1992).

Also listed in appendix 1, USGS section, are additional geologic and mineral-resource reports for the Cordova and Middleton Island quadrangles (Goldfarb and others, 1992; Winkler, Plafker, and others, 1992), the Mount Hayes quadrangle (Koch and others, 1993; Nokleberg, Aleinikoff, and others, 1992), the Gulkana A-1 quadrangle (Richter and others, 1992), the Valdez quadrangle (Winkler, Goldfarb, and Plafker, 1992), and northern Alaska (Moore and others, 1992a, 1992b).

\section{PRECIOUS METALS}

USGS geologists are involved in several studies of precious-metal occurrences in Alaska. Present research focuses on placer-gold deposits in the Fortymile district, guidelines for lode-gold exploration in central Alaska, and turbidite-hosted lode gold in the Seldovia quadrangle. Many level III AMRAP studies also involve research related to precious-metal deposits. Reports published in 1992, and listed in appendix 1, USGS section, include (1) fluid-inclusion study of the Rock Creek area, Nome mining district, Seward Peninsula (Apodaca, 1992); (2) geochemistry of lode-gold deposits, Nuka Bay district, southern Kenai Peninsula (Borden and others, 1992); (3) placer gold of the Kenai lowland (Cieutat and others, 1992); (4) experimental abrasion of detrital gold in a tumbler (Yeend, 1992); (5) gold in the coals of the Usibelli Group, Nenana Coal Field (Stricker and others, 1992); and (6) plutonic contact-related mineralization and volcanichosted epithermal vein mineralization in the Cold Bay and False Pass quadrangles (Wilson, Miller, and Detterman, 1992).
Table 8. Level IV studies of the USGS Alaska Mineral Resource Assessment Program and related projects active in 1992

[Project chiefs are listed in parentheses. Projects marked by asterisk are of statewide scope]

Areal mineral-resource assessments

Alaska Peninsula, geology and mineral resources (F.H. Wilson)

Colville mining district, geology and mineral resources

(J.H. Dover, USGS; S. Fechner, USBM)

Eastern Alaska Range, metallogenesis (W.J. Nokleberg)

Fortymile district, placer-gold deposits (W.E. Yeend)

Juneau gold belt, lode-gold deposits (R.J. Goldfarb)

Norton Bay-Unalakleet area, geology and mineral resources (W.W. Patton, Jr.)

*Placer-gold deposit studies (W.E. Yeend)

*Tin commodity studies (B.L. Reed)

Western Brooks Range, mineral deposits (J.M. Schmidt)

Framework or process studies

*Alaska mafic and ultramafic rocks (R.A. Loney)

*Alaska metamorphic-facies map (C. Dusel-Bacon)

Alaska Peninsula, upper Mesozoic stratigraphy (F.H. Wilson)

Central Alaska metamorphic studies and structural analysis (J.H. Dover)

Chugach massive sulfide deposits, geochemistry (S.W. Nelson)

Greens Creek lead-zinc-silver massive sulfide deposit

(R.S. Newberry and D.A. Brew)

Groundhog Basin-Glacier Basin silver-tin-lead-zinc deposits (R.J. Newberry and D.A. Brew)

Jualin and Kensington low-sulfide gold-quartz vein deposits (R.S. Newberry and D.A. Brew)

Northwestern Alaska crustal study (A.B. Till)

*Paleomagnetism of accreted terranes (C.S. Gromme)

Salt Chuck platinum-palladium deposits (R.A. Loney)

Seward Peninsula gold veins (B.M. Gamble)

Exploration geochemical studies

Western Brooks Range, stratabound base-metal deposits (K.D. Kelley)

Southwestern Alaska, epithermal mineral deposits (J.E. Gray) Admiralty Island, geochemistry (C.D. Taylor)

\section{STRATEGIC AND CRITICAL MINERALS}

Current research on the occurrence of strategic and critical minerals in Alaska includes studies of mafic and ultramafic rocks and their associated deposits of platinumgroup metals (PGM), chromium, nickel, and cobalt. A palladium-rich intrusion on Prince of Wales Island has also been examined (Loney and Himmelberg, 1992). Tin commodity studies are ongoing.

\section{OTHER METALS}

The Prince William Sound region hosts more that 600 known massive-sulfide copper-lead-zinc deposits, which 
vary in size from less than 1 million to greater than 5 million metric tons of mineralized material. Historically, the deposits have been described as epigenetic vein, replacement, and shear-zone hosted ores. A new study groups the deposits into two genetically related, yet geochemically distinct, types of deposits that are related to submarine volcanism: the first type, hosted in submarine basalts and tuffs, is analogous to Cyprus-type mineralization; the second type, hosted in volcano-sedimentary sequences, is analogous to the Besshi-type deposits of Japan (Crowe and others, 1992).

The copper-lead-zinc-gold-silver deposits of the southern Yukon-Tanana region have been delineated into three districts (Lange and others, 1993). The Delta district is the largest of the three and contains at least 35 deposits in an 800 -square-kilometer area. Larger deposits range between 1.6 and 18 million metric tons of mineralized material, with combined grades of 8 to 11 percent total copper-leadzinc, $62 \mathrm{~g} / \mathrm{t}$ silver, and $1.9 \mathrm{~g} / \mathrm{t}$ gold.

A summary article on the porphyry copper, molybdenum, and gold deposits of Alaska for the new volume on porphyry deposits of the northwestern Cordillera is being prepared by the Canadian Institute of Mining, Metallurgy, and Petroleum.

\section{STATEWIDE MINERAL-RESOURCE ASSESSMENT}

A new State of Alaska Mineral Resource Assessment Program (SAMRAP) has been initiated for the compilation of geologic and mineral-resource data at a scale of $1: 2,500,000$; the tectonic-magmatic base map is in preparation. The purpose of the assessment is to (1) prepare tables of significant lode and placer deposits by revising data from the MRDS into an Alaskan Resource Data File (ARDF); (2) prepare regional maps, with data tables, showing permissive mineral-resource assessment tracts; and (3) prepare quantitative estimates of undiscovered mineral resources for selected tracts. SAMRAP involves members of the Branches of Alaskan Geology, Geophysics, Geochemistry, and Resource Analysis.

\section{COOPERATIVE PROGRAMS WITH FOREIGN SCIENTIFIC AGENCIES}

In 1987, joint studies were proposed to the then-Union of Soviet Socialist Republics (USSR) Academy of Sciences during a visit to the Soviet Far East by the USGS Chief Geologist and the USGS Branch Chief of Alaskan Geology. In 1988, two study proposals were exchanged, and memoranda of understanding were signed in 1989 between the National Science Foundation and the Academy of Sciences.

The first project involves the comparative tectonics and metallogenesis of lode mineral deposits in the Russian Far East and Alaska. In 1989, a team of USGS geologists visited the Far East for 5 weeks. In 1990, the
State of Alaska joined the USGS in sponsoring visits to Alaska by two teams of Soviet geologists. In 1991, the Geological Survey of Canada joined the project, and a poster session outlining the comparative metallogeny of the Russian Far East, Alaska, and the Canadian Cordillera was presented at the McKelvey Forum in Reno, Nevada. The North American metallogenesis team traveled to the Russian Far East to work with their collaborators on metallogenic and tectonic maps, explanations, and interpretative articles; maps are being compiled at a scale of $1: 5,000,000$.

In 1992, substantial progress was made on editing and revising the Russian, Alaskan, and Canadian data sets on metallogenic maps, mineral-deposit maps and tables, terrane maps and explanations, and interpretative texts on metallogenesis of the region, known as the Circum-North Pacific Terrane. The compiled offshore geology was merged with the onshore data for the Russian Far East, and compiled onshore geology of the Canadian Cordillera was merged with data for Alaska and the Pacific Northwest. The Russian Far East metallogenesis team toured field sites in southern and central Alaska. Geologic work sessions were held in Anchorage, Alaska; Vancouver, Canada; and Menlo Park, California. Papers listed in appendix 1, USGS section, include the preview CircumNorth Pacific Terrane map presented at the International Geological Congress in Japan (Nokleberg, Grantz, and others, 1992a) and at the International Conference on Arctic Margins in Anchorage (Nokleberg, Grantz, and others, 1992b), as well as a paper on the metallogenesis of the Russian Far East presented at the Northwest Mining Association's Annual Convention in Spokane (Nokleberg, Eremiin, and others, 1992). At the 1993 convention, the Northwest Mining Association will include a one-day symposium and one-day poster session on the metallogenesis of the Russian Far East, Alaska, and the Canadian Cordillera.

The second project encompasses a joint comparative study of the geologic setting and age of ophiolites and their host terranes in Alaska and the Russian Far East. Ophiolites typically mark fossil boundaries of crustal plates, and the study of ophiolites could lead to insights into the mechanisms of plate subduction and terrane accretion. Moreover, ophiolites commonly are associated with mineral deposits of copper, chromium, nickel, and cobalt. Soviet geologists toured several Alaska ophiolite deposits in 1989, and U.S. geologists visited important ophiolite localities in the Russian Far East in 1990. Reciprocal joint work sessions were held in Russia in 1991 and in Alaska in 1992. All Alaskan components of the project have been released as USGS open-file reports and are listed in appendix 1, USGS section (Burns, 1992; Foley, 1992; Nelson, 1992; Patton, 1992a, 1992b; Patton and Box, 1992; Patton and others, 1992). In 1993, the Russians will prepare their materials for review by USGS geologists prior to publication. 
The TACT program is an integrated, multidisciplinary study of the earth's crust along a transect from the Gulf of Alaska to the Arctic Ocean. The program combines data from geologic and geophysical surveys to decipher the deep-crustal structure of Alaska, using geologic mapping; specialized structural, isotopic, geochemical, and paleontologic studies; seismic reflection and passive seismic studies; magnetotelluric studies; and gravity and magnetic surveys. Although mainly a deepcrustal structure program, results of the TACT program are used for mineral-resource assessment studies, formulation of tectonic models of mineralization, and minerals exploration by private industry.

In 1992, helicopter-supported field studies were conducted in the northern Brooks Range and southern North Slope. Funding was obtained for major magnetotelluric surveys in southern and east-central Alaska. Field and laboratory data were compiled. Pertinent articles in appendix 1, USGS section, include (1) deep-crustal structure of the southern Yukon-Tanana terrane (Beaudoin and others, 1992); (2) deep-crustal structure of the Alaska Range (Fisher and others, 1993); and (3) extensional tectonics of the Yukon-Tanana terrane (Pavlis and others, 1993).
A cooperative 4-year study of nonfuel-mineral resources of the Colville mining district in the southern portion of the NPRA was initiated by the USGS and the USBM in 1990. The overall objective of the study is to evaluate the mineral potential of the district to aid the BLM in their land-planning decisions. The evaluation will include a USBM compilation of data on known deposits and USGS estimates of undiscovered mineral resources. Field work in 1992 included detailed geologic mapping, structural analyses, paleontologic sampling, and stratigraphic investigations.

A study of the geochemically anomalous areas in the west-central part of the Howard Pass quadrangle, NPRA, presented evidence for sediment-hosted zinc-lead-silverbarium mineralization (Kelley and others, 1992). Four new barite deposits were discovered during the course of geologic mapping in the central Howard Pass quadrangle by USGS geologists in 1990 and 1991 (fig. 17), and three additional barite deposits were found by USGS and USBM geologists in 1992. The USBM estimates that there are about 50 million metric tons of barite in these deposits. Previously known resources of barite in the United States were estimated at about 100 million metric tons. A report

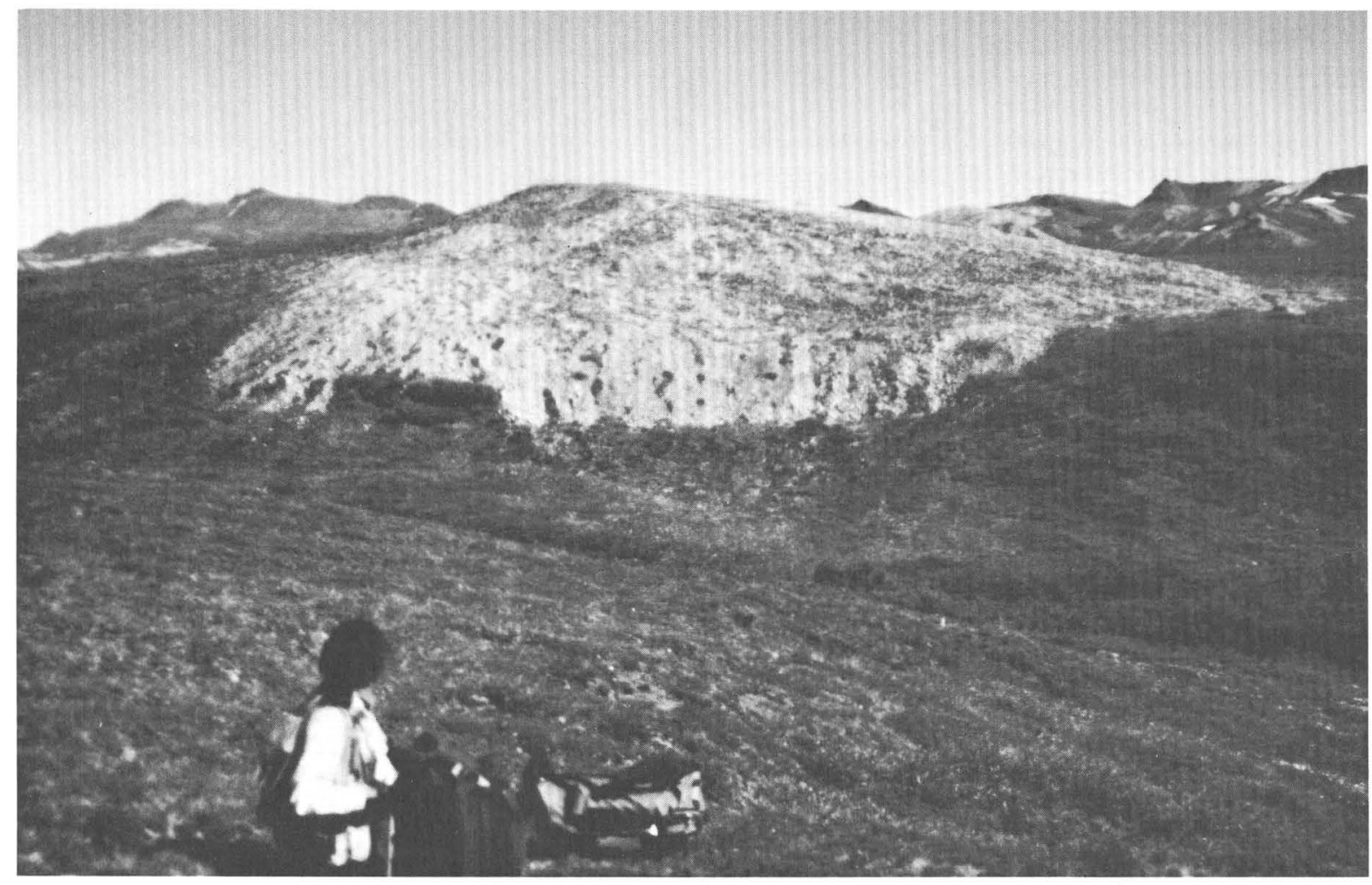

Figure 17. The Stack barite deposit in the Cutaway Basin, central Howard Pass quadrangle. This is one of several barite deposits that have been discovered during the BLM-USGS-USBM cooperative evaluation of the Colville mining district in southern NPRA. Outcrop measures 20 meters across and 3 meters high. Photograph by J. Schmidt. 
describing the geology and resource potential of the new barite deposits has been published (Kelley and others, 1993).

\section{U.S. BUREAU OF MINES}

The USBM's AFOC is responsible for conducting four programs under the USBM's Directorate of Information and Analysis and for coordinating work with other USBM field and research centers throughout the United States. The USBM's Research Directorate is responsible for several ongoing projects in Alaska, through both the Mineral Institute program and the nine USBM research centers.

\section{MINERALS AVAILABILITY PROGRAM}

The USBM studied submarine tailings disposal, developed Alaskan cost factors for mineral development, and compiled costs for gold and copper leach operations and other ancillary operations. The USBM MAS data base was revised with new data and received widespread use from the public sector.

Submarine tailings disposal.-In many coastal situations, the submarine disposal of mill tailings (processed mineral waste) may be the preferred method of disposal from a logistical and environmental standpoint. In 1991, the USBM initiated studies to assess the technology, environmental aspects, and current regulations related to this method of disposal, and to project effects on the availability of minerals from American sources if this disposal technique were permitted in the United States. During 1992, the USBM released an overview and extensive bibliography about submarine tailings disposal (Baer, Sherman, and Plumb, 1992). The University of British Columbia, working under a cooperative agreement with the USBM, compiled a volume of four submarine-disposal case studies, to be released in 1993; a second volume will also be produced in 1993. Other USBM reports that cover the technology, environmental aspects, and regulatory conditions of submarine disposal of tailings are near completion. The USBM will continue these studies during 1993.

Alaskan cost factors.-The USBM developed a comprehensive set of cost escalation factors for use in performing development feasibility studies on Alaskan mineral deposits. The factors allow for the escalation of capital and operating costs from Denver-based values to reasonable estimates for any region in Alaska. Factors for capital plant and equipment, labor, and electrical power were derived through a detailed comparison of costs in the lower 48 States. A report describing these factors and their use is scheduled for publication in 1993.

Cost estimating system.-As part of the USBM's update of its Cost Estimating System, costs for the design and construction of gold and copper leach process plants, development earthwork, electrical systems, engineering and management fees, mine dewatering, drainage and disposal systems, buildings, and other support facilities were compiled. When used with other process costs in the System, total costs for mining or beneficiation can be determined.

Public information.-The MAS data base was maintained and enhanced by the entry of field data from the Valdez Creek mining district. Collection of mineral property data from the Commonwealth of Independent States continued during 1992. The data will be used for comparative cost and availability studies. The MAS data base also received widespread use by industry, government, and the public sector. Mineral data were provided in digital format and as map overlays and deposit reports to the State of Alaska, Alaska Native corporations, the USFS, mineral consultants, and private individuals.

\section{POLICY ANALYSIS}

The USBM continued to study the mine permitting process and its impact on mine development, to evaluate the impact of proposed Federal solid-waste regulations on mineral development in Alaska, to analyze the economic impacts of land planning on mining in the Tongass National Forest, and to evaluate the impact of "ecosystem management" concepts on mineral development. The MCIS was maintained.

Mine permitting in Alaska and British Columbia.Canada and the United States have well-developed regulatory systems for evaluating the environmental impacts and permitting of mines. Objectives of USBM studies are to develop (1) detailed case studies of mine permitting requirements and processes, and (2) a comparative analysis of environmental regulatory structures and permitting required for mine development in Alaska and British Columbia. appendix 1, USBM section, lists three case studies of mines in Alaska and British Columbia released by the USBM in 1992 (Brownlow, 1992; Hemming and CocklanVendl, 1992; Gardner, 1992), as well as a preliminary analysis of the effects of environmental regulation on mines in southeastern Alaska (McDonald and Martin, 1992). A comparative analysis of mine permitting in Alaska and British Columbia was also completed and will be released in 1993 .

Resource Conservation and Recovery Act (RCRA).The USBM initiated a study to assess the impact on the Alaskan mining industry of proposed Federal regulations (RCRA Subtitle D) on solid-waste handling and disposal, taking into account the unique environmental conditions found in Alaska. Two reports listed in appendix 1, USBM section, discuss tailings and waste-rock management under the proposed regulations (Brodie, Banta, and Skermer, 1992a, 1992b).

Tongass National Forest Land Management Plan.Revision of the Tongass Land Management Plan by the 
USFS affects the availability of land for mineral entry and development. For several years, the USBM has assisted the USFS in studying the revision's impact on the Alaskan mineral industry (Daniel, 1992). A separate study has quantified the economic impact of the minerals industry on southeastern Alaska; this includes mineral activity in British Columbia that is supported from southeastern Alaskan bases (McDowell Group, 1992).

Ecosystem-based regulations.-The USFS is one Federal land management agency that incorporates "ecosystem management" concepts into its land planning and management efforts. The USBM is developing an analytical framework, including Alaska-based studies, for evaluating the mining-related implications of these proposed policies and regulations.

Mining claim information system.-The MCIS was updated with claim data through February 1991. During 1992, the USBM filled numerous requests for copies of the software.

STATE MINERAL ACTIVITIES

The State Mineral Officer wrote the annual preliminary "Mineral Industry Survey of Alaska in 1991," summarizing significant nonfuel-mineral activity. Legislative and executive actions of interest to the mineral industry were monitored and reported monthly. News items were prepared for the weekly "Mineral Alerts" and for the bimonthly survey "Minerals and Materials." Mineral briefing profiles were prepared for DOI and USBM officials as required. Mineral news of interest to USBM staff and its commodity specialists was forwarded to them weekly.

Minerals information and analysis are provided through a series of scheduled and unscheduled publications and reports, and through other responses to inquiries from State and Federal agencies, industry, and the public. One priority is the identification and evaluation of issues, problems, and trends in order to provide the USBM additional opportunities for constructive action in the minerals field.

\section{MINERAL LAND ASSESSMENT}

During 1992, the USBM conducted mining district studies, site-specific mineral investigations, abandonedmine land activities, and forest planning studies in Alaska (fig. 18, table 9). Each mining district study is designed to determine the mineral-development potential of the district by inventorying mineral resources and reserves, evaluating the probability that more resources exist, and determining the feasibility of mining certain deposit types. The studies include site-specific evaluations when the presence of significant minerals is noted. The mining district studies are done in cooperation with Federal and State agencies. In 1992, the USBM investigated the Colville and Ketchikan mining districts.
Colville mining district.-The Colville mining district is located in northern Alaska and includes the southern part of NPRA. For 56 days in 1992, the second year of the program, the USBM performed regional reconnaissance work from Spike Creek eastward to Ivotuk Hills. Site-specific investigations were conducted on mineralized occurrences between Rolling Pin and Ivotuk Creeks. A total of 350 rock, soil, and stream-sediment samples were collected. Three new mineral occurrences were found during areal reconnaissance. In the headwaters of Safari Creek, massive lenses and pods of galena with subsidiary sphalerite and minor chalcopyrite are exposed along the trend of an east-west shear zone. Select samples of the massive zone contained up to 46 percent lead, 12 percent zinc, and $685 \mathrm{~g} / \mathrm{t}$ silver; stringer sulfides adjacent to the massive zone assayed at 22 percent lead, 7 percent zinc, and $274 \mathrm{~g} / \mathrm{t}$ silver. Three new barite deposits were also discovered by USBM and USGS geologists. Five barite deposits that were discovered in 1990 and 1991 were examined, and the USBM identified estimated resources ranging from 155,000 to 10 million metric tons. Samples from the Cutaway Creek deposit averaged 95.9 percent $\mathrm{BaSO}_{4}$, and the deposit has an inferred resource of 3.8 million metric tons. Samples from the Cula Creek deposit averaged 95.3 percent $\mathrm{BaSO}_{4}$, and the occurrence contains an inferred resource totaling 29.5 million metric tons. Nine previously discovered mineral occurrences were also examined. In the Story Creek area, a 2.2-kilometer-long zone of en echelon dilational quartz-cemented breccia lenses contain sulfides assaying up to 11 percent zinc, 2.8 percent lead, $51.0 \mathrm{~g} / \mathrm{t}$ silver, and 1,366 parts per million (ppm) copper. The Lisburne Ridge area was examined to evaluate phosphate occurrences. Samples of the phosphates averaged 24.3 percent $\mathrm{P}_{2} \mathrm{O}_{5}$ and also contained up to $94 \mathrm{ppm}$ uranium; samples of the enclosing shale contained up to $2,000 \mathrm{ppm}$ vanadium. Although poorly exposed, the phosphates were traced intermittently along strike for 5 kilometers.

Ketchikan mining district.-The third year of study continued during 1992 in the Ketchikan mining district in southeastern Alaska. The district is endowed with a diverse variety of lode deposits that include gold, silver, molybdenum, PGM, tungsten, and rare-earth elements (REE). The USBM examined 196 mineralized localities in the Helm Bay, Gravina Island, Ketchikan, and Hyder areas. From these sites, 1,689 samples and 3 bulk metallurgical samples were collected. Approximately 8.5 kilometers of underground workings were mapped. The ADGGS, under a cooperative contract, conducted regional mapping activities in the Helm Bay and Hyder areas.

Site-specific mineral investigations.-Through field studies, deposit modeling, and beneficiation and metallurgical testing, the USBM conducts site-specific investigations to locate, characterize, and quantify deposits that contain strategic and critical minerals and advanced materials. The USBM has investigated occurrences of 


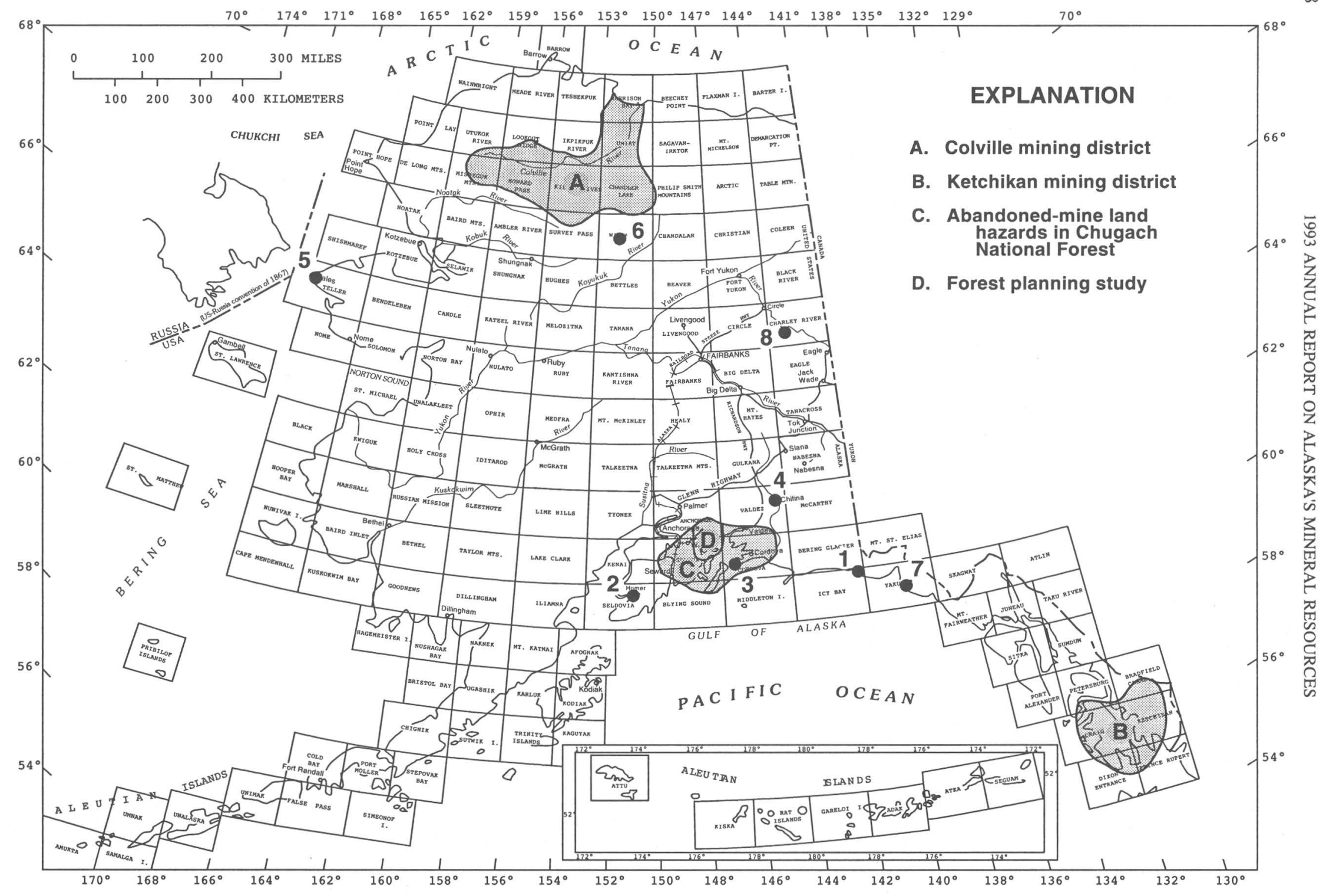

Figure 18. Locations of 1992 USBM study areas listed in table 9. 1:250,000-scale quadrangles are outlined and labeled. 
Table 9. U.S. Bureau of Mines study areas in 1992

[Locations shown on figure 18. REE, rare-earth elements; PGM, platinum-group metals]

\begin{tabular}{|c|c|}
\hline Area of study & $\begin{array}{c}\text { Deposit or element } \\
\text { of major interest }\end{array}$ \\
\hline \multicolumn{2}{|c|}{ Mining districts } \\
\hline $\begin{array}{l}\text { A. Colville mining district .............. } \\
\text { B. Ketchikan mining district ........... }\end{array}$ & $\begin{array}{l}\text { Lead, zinc, barite, } \\
\text { phosphate, coal } \\
\text { Placer and lode gold, } \\
\text { massive sulfide, } \\
\text { chromium, PGM, REE }\end{array}$ \\
\hline \multicolumn{2}{|c|}{ Site-specific mineral investigations } \\
\hline 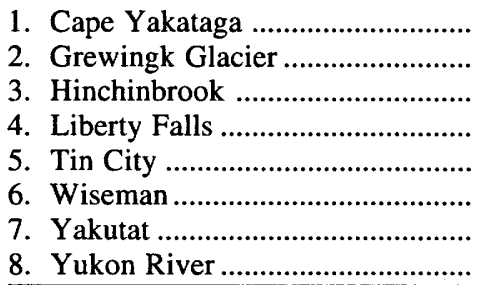 & $\begin{array}{l}\mathrm{Ti} \\
\mathrm{Mn} \\
\mathrm{Mn} \\
\mathrm{Mn} \\
\mathrm{Sn}, \mathrm{In} \\
\mathrm{Mn}, \mathrm{V} \\
\mathrm{Ti} \\
\mathrm{V}\end{array}$ \\
\hline
\end{tabular}

\begin{tabular}{l} 
Abandoned-mine land hazards \\
\hline C. Chugach National Forest \\
Forest planning \\
\hline D. Unakwik \\
\hline
\end{tabular}

chromium, cobalt, gallium, germanium, indium, manganese, niobium, PGM, REE, tantalum, tin, vanadium, yttrium, and zirconium at nearly 300 sites in Alaska (fig. 3 ). Currently, the USBM is evaluating the exploitation potential of Alaska's indium, manganese, titanium, and vanadium resources. Data on indium in hydrothermal tin deposits in Alaska are being compiled and analyzed, and sampling at the Lost River property indicated that the deposit contains anomalous amounts of indium.

Deposits with high manganese values were examined near Grewingk Glacier, Hinchinbrook Island, Liberty Falls, and Wiseman. In general, these deposits are hosted in the cherty layers of mafic volcano-sedimentary rock sequences. At Grewingk Glacier, a massive 0.3-meter-thick mineralized layer assayed 26 percent to 32 percent manganese; the bed could be traced for 117 meters along strike. Similar mineralization was found nearby at Dixon Glacier, where a mineralized boulder was collected that assayed 29 percent manganese. On Hinchinbrook Island, manganese content of massive mineralization ranged from 17 to 31 percent; a chert boulder containing 20 percent manganese also contained anomalous amounts of gallium, silver, molybdenum, barium, bismuth, and tellurium. A manganese deposit examined at Liberty Falls was traced along a northwest-trending ridge for about 1 kilometer; samples taken from the deposit were manganese-poor and iron-rich.
In the Wiseman area, the USBM found numerous small rubble occurrences of manganese mineralization; samples contained from 16 to 26 percent manganese. At other locations here and in the Alatna Hills, psilomelane-coated chert rubble appears to represent secondary manganese concentrations; manganese contents ranged from 2 to 9 percent. None of the mineralized rubble crops extend for more than 30 meters in any direction.

Geologic and mining claim data are being compiled for the USBM's titanium resource investigation. At Cape Yakataga and at Yakutat, sampling programs were conducted in 1992 to develop a process for evaluating onshore marine beach placers in Alaska and to complete initial field investigations of the two pilot study areas. More than 7,000 kilograms of heavy-mineral-bearing sand, containing ilmenite, magnetite, garnet, zircon, rutile, gold, and small amounts of PGM, was collected in 455 hand-auger, powerauger, and channel samples (fig. 19). The samples are being processed for size analysis, chemical and mineralogical characterization, and beneficiation tests at the USBM's Salt Lake City, Utah, and Albany, Oregon, research centers.

During the assessment of vanadium potential in Alaska, the USBM visited areas near Wiseman and Eagle. In the Wiseman quadrangle, data from the National Uranium Resource Evaluation (NURE) indicated widespread vanadium, zinc, copper, and tungsten anomalies in stream sediments; rock sample values ranged from 141 ppm to 1 percent vanadium. NURE data also showed high vanadium values in the Eagle and Charley River quadrangles. Investigations revealed a black shale that contains up to $2,000 \mathrm{ppm}$ vanadium, $188 \mathrm{ppm}$ uranium, and 1,439 ppm copper in select basal layers.

Abandoned mine land inventory.-In 1989, the USFS requested the USBM to locate and assess the physical and environmental hazards associated with abandoned-mine sites in the Chugach National Forest. A cursory evaluation of the mine sites indicated that 100 properties contained potentially serious hazards. During 1992, USFS and USBM personnel visited 17 sites and documented such hazards as dynamite and blasting caps, underground workings, collapsed buildings, machinery, and scrap metal and lumber. Soil samples were collected in areas of potential contamination. USFS personnel will use the information from these assessments to develop plans for mitigation and remediation.

Alaska forest studies.-The USFS requested the USGS and the USBM to conduct geologic investigations in an area of the Chugach National Forest between Unakwik Inlet and Columbia Glacier in Prince William Sound. USGS scientists studied the structural and mineralogical aspects of the regional geology while USBM personnel assessed the economic potential of mineral occurrences. The USBM collected samples at 25 mineralized sites for use in estimating the size and grade of each deposit. The USFS will use the results in its pending revision of the Chugach National Forest management plan. 


\section{MINING RESEARCH}

Mine closure in arctic and alpine environments.-The goal of this research is the development of reclamation and closure technology for placer-gold mines situated in fragile environments. The project concentrates on the field evaluation of emerging technologies and innovative methods being developed by small mining operations and regulatory agencies to deal with the reclamation problems related to placer mines: stream diversion technology; methods of recontouring slopes and hillsides; and mining methods that maximize resource recovery so that once an area is mined and reclaimed, it need not be mined again in the future. This research has been done in cooperation with the BLM, USFS, and the Alaska Division of Mining.

Subaqueous disposal of mining wastes.-This project addresses the environmental and economic feasibility of disposing mineral-processing wastes in a marine environ-

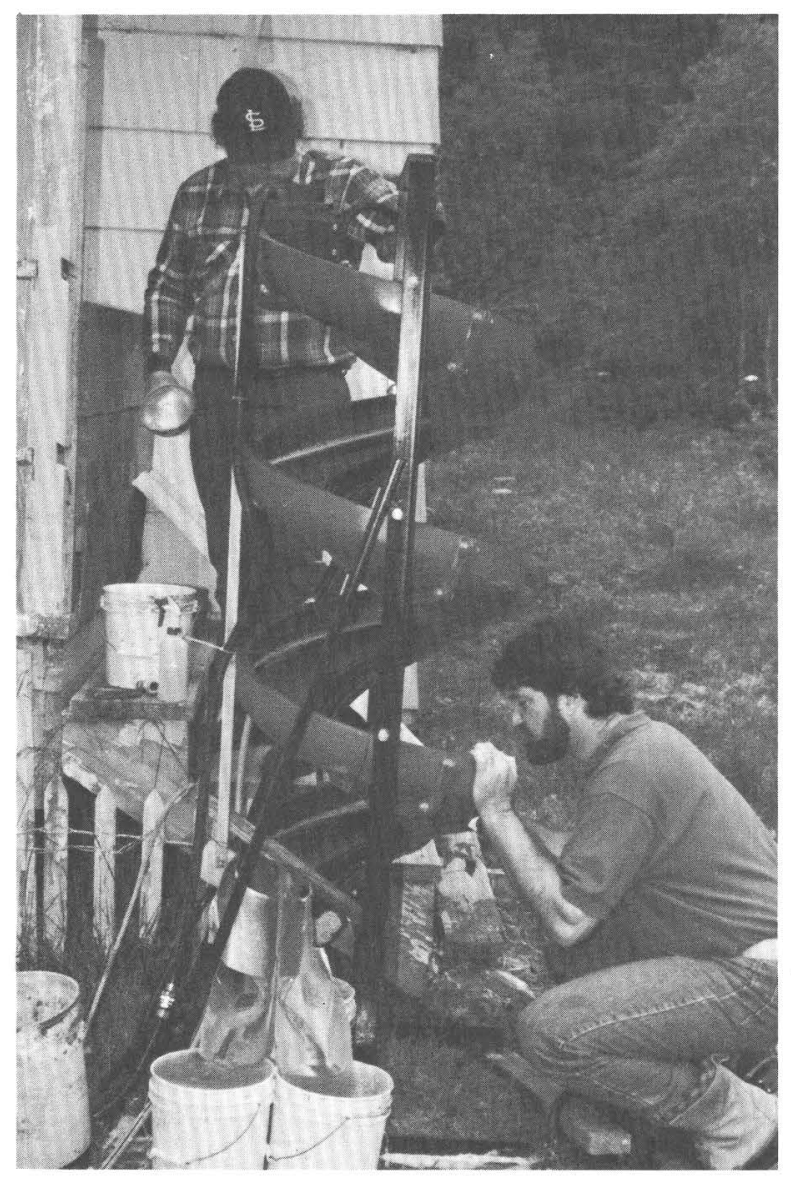

Figure 19. Spiral separator used to concentrate heavy minerals in beach sands at Cape Yakataga. The USBM sampling program is designed to evaluate the titanium-resource potential of the onshore marine beach placers in the area. Photograph by J. Foley. ment. Samples of tailings effluent were collected at the Greens Creek Mine and used in laboratory tests to determine if tailings would dissolve in an oxygen-deficient marine environment; preliminary test results indicate only minor dissolution of metals. Computer simulations will be used to predict the long-term impacts of the dissolved metals on a marine environment. In the near future, other types of tailings will be similarly tested, and old subaqueous disposal sites along the Alaskan coast will be examined to determine their impact on the marine environment.

Analysis of underground mining.-This project evaluates new mine design technologies and applies these technologies to mining in Alaska. It is difficult in Alaska to assess the alternative mining methods for maximized resource recovery and minimized waste and environmental impact. Computer-generated mining simulations are being used in this project to evaluate options without the costly development and field testing that is normally required. Geotechnical data are being gathered from the Greens Creek Mine in southeastern Alaska to verify the computer simulations. Ultimately, these modeling techniques will be used to design mines that optimize resource recovery, ensure workers' health and safety, and minimize environmental impact.

Mining in permafrost.-This project strives to develop economic, safe, and environmentally sound techniques for mining in permafrost. To better understand the behavior of permafrost, a field study was initiated at the Dome Creek drift mine, a small underground placer operation near Fairbanks. Instruments were installed in a section of the mine to measure the vertical convergence of the roof and floor. The data collected will be used to quantify the behavior of frozen silts and gravels and to identify prominent failure mechanisms for frozen materials. The structural response of the mine will be analyzed in order to define mine design criteria for underground openings and pillars in permafrost.

Borehole slurry mining.-A prototype Borehole Placer Mining System was successfully tested in a frozen placer deposit on Tenderfoot Creek near Fairbanks. The prototype was designed and fabricated at the USBM's Twin Cities Research Center. The system uses two down-hole miners in adjacent boreholes; each miner is equipped with a water jet that cuts an opening in the direction of the other hole. After an underground chamber connects the two boreholes, the jetting system of one miner and the pumping system of the other are operated in unison to flush and lift the gravels from underground. In the field test, the two-borehole arrangement produced three times as much gold as a single borehole. The test also pointed out several deficiencies in the equipment and procedures, solutions to which are being developed and evaluated in another test in 1993.

Bacteria treatment of mine waste water.-The USBM has spent approximately $\$ 1$ million during the 
past 5 years to study the bacterial treatment of cyanide in mine waste water. Cyanide is often used to extract gold from crushed ore, and most mines rely on chemical treatments to break down the cyanide before disposal. Cyanide-eating bacteria often create cleaner waste water than do traditional chemical methods, but the bacteria become extremely sluggish in colder climates. At the University of Alaska's Institute of Arctic Biology in Fairbanks, the USBM is helping to fund research that is designed to help the bacteria adapt to Alaska's harsh climate Eight crates of the bacteria have been buried in an ore pile at Citigold's Ryan lode-gold mine on Ester Dome near Fairbanks; the microbes' survival will be monitored through the winter.

Frozen tailings as backfill material.-The use of frozen tailings and waste rock as backfill material in an underground mining operation is being assessed. Physical and chemical stability of this material is important in evaluating its potential for long-term deposition. Freezethaw cyclic tests were conducted on frozen placer gravel samples to simulate seasonal temperature variations; test results showed minimal mobilization of the residual metals. Additional research revealed that the presence of dissolved salts in the saturation solution did not affect the freezing of the material or the solubility of the metals. Continuing research will investigate the effect of acidity on the chemical stability of the frozen fill materials.

Process mineralogy of Alaskan resources.-Mineral characterization and beneficiation studies continue to examine bulk samples of Alaskan mineral deposits. Grinding tests on samples from the Story Creek deposit showed that the lead and zinc minerals are liberated from the host rock at a coarse size, around 300 microns; a combined gravityflotation technique recovered 96 percent of the zinc and 74 percent of the lead. Current research is examining mineral concentrates and tailings produced from the bulk samples collected at Cape Yakataga and Yakutat. Results of this study will determine if those beach sands are an economic resource for titanium, zirconium, REE, and precious metals. Future research on the Ivotuk Hills phosphate is planned to determine if this material is suitable for producing fertilizer-grade phosphoric acid.

Evaluation of Alaskan precious metal resources.Five gold ores from Prince of Wales Island were evaluated for their amenability to conventional recovery methods; the study concluded that all five ores exhibit refractory traits and probably would require pretreatments to ensure adequate gold recovery. Future work will examine other gold deposits.

Evaluation of Alaskan strategic and critical mineral resources.-Tests of Alaskan tin and chromium ores indicated that beneficiation of ultrafine particles in these ores will be a generic problem. The Mosley Multigravity concentrator was useful, however, for concentrating chromite particles in the 5-micrometer range.
BUREAU OF LAND MANAGEMENT

In the 1992 assessment year (September 1991 to September 1992), there were filings/recordings of a total of 24,617 Federal mining claims in Alaska. The total number of active mining operations on BLM-administered lands included 128 Notices, which cover 20,234 square meters or less total surface disturbance, and 100 Plans of Operations, which cover more than 20,234 square meters of total surface disturbance. Decisions were issued that resulted in the closure of 4,650 claims. Five mineral patents were adjudicated to completion, and two mineral patents covering 14 claims were issued. Three applications covering 29 claims were rejected.

Geologists, support personnel, and field personnel from the BLM Arctic District Office accompanied and cooperated with the USBM's field work for the Colville mining district study of metallic minerals in the southern NPRA.

\section{U.S. FISH AND WILDLIFE SERVICE}

Valid mining claims on lands established as national wildlife refuges by the ANILCA in 1980 remain valid if they are kept active. In 1992, there were 135 claims on 8 of the 16 refuges in Alaska, including 1 in the Alaska Maritime NWR, 70 in the Alaska Peninsula NWR, 9 claims and 1 mill site in the Arctic NWR, 1 in the Becharof NWR, 2 in the Innoko NWR, 4 in the Tetlin NWR, 35 in the Togiak NWR, and 13 in the Yukon Delta NWR. The mill-site claim and four placer claims in the Arctic NWR are suspected of being maintained for nonconforming uses of a mining claim; in 1992, the claimant was asked to either relinquish the claims or prove their validity.

Based on previous field work, the FWS prepared reports in 1992 of contaminant monitoring in the Innoko, Koyukuk, Nowitna, and Selawik NWR's, where placer mining occurs upstream of the refuges. The FWS also reviewed $21 \mathrm{ACE}$ permits or permit modifications for mining-related activities. The FWS monitored the Greens Creek silver mine and participated in investigations, planning, and permit review of the proposed A-J and Kensington gold mines in southeastern Alaska.

\section{MINERALS MANAGEMENT SERVICE}

Onshore mining of stream and beach placers near Nome has occurred intermittently since the first gold discoveries in 1899. Since that time, miners have recovered over 186,620 kilograms of gold from the Seward Peninsula, of which over 139,965 kilograms came from the Nome mining district. From 1986 to 1990 , the Western Gold Exploration and Mining Company (WestGold) used the floating dredge Bima to mine 88 square kilometers of mineral leases in State of Alaska waters near Nome, 
extracting approximately 4,043 kilograms of gold. Industry responses to a Request for Comments and Nominations in March 1988 indicated that sufficient interest existed to justify a gold sale in the Federal OCS waters of Norton Sound.

The MMS scheduled the OCS mineral lease sale for areas south and southeast of Nome for 1991. The proposed sale area encompassed 595 square kilometers on the OCS and extended up to 16 kilometers seaward of the State of Alaska's 4.8-kilometer coastal water limit. Preliminary studies had indicated that the sale area could yield as much as 32,970 kilograms of gold in placer deposits at or near the sea floor at depths ranging from 18 to 30 meters. The Final EIS for the sale was released in March 1991, the Final Leasing Notice issued in June, and the sale held in July; however, no bids were received by the deadline, so the sale was canceled. High operating costs and low gold prices had forced Westgold to cease production in late 1990 , and this may have been a contributing factor to the sudden disinterest in the sale.

\section{NATIONAL PARK SERVICE} lows:

Major NPS accomplishments during 1992 are as fol-

1. In 1991, the Ninth Circuit Court affirmed the approval of EIS's prepared by the NPS for Denali, Wrangell-St. Elias, and Yukon-Charley Rivers NP\&P's. Subsequently, the NPS continued to accept plans of operations for mining activities in these three units in addition to other NPS units in Alaska. In 1992, the NPS took action on eight plans of operations in three units: (1) in Bering Land Bridge National Preserve, a plan of operations was received and rejected for lack of information, but the revised plan was accepted at the end of the year, and environmental and engineering analyses will begin on the plan in 1993 (fig. 20); (2) in Denali NP\&P, the NPS continued the review and resolution of boundary differences in one claimant's plan of operations; reviewed and rejected two plans of operations for lack of information; denied one plan of operations because the engineering design was not technically feasible and did not include complete recycling of processing waters; and began the preparation of the environmental and engineering analyses on a fifth plan of operations; and (3) in Wrangell-St. Elias NP\&P, one plan of operations was approved, and the environmental and engineering analyses were begun for a second plan. Mining occurred under an approved plan of operations in Kenai Fjords National Park, and mining operations continued on a previously approved plan of operations in Wrangell-St. Elias NP\&P.

2. The preferred alternative selected in the approved EIS's for Denali, Wrangell-St. Elias, and Yukon-Charley Rivers NP\&P's was the acquisition, on a "willing seller" basis, of all patented and valid unpatented mining claims in the named park units. The mining-claim acquisition program's current funding level of $\$ 7.5$ million includes $\$ 2.9$ million appropriated for Fiscal Year 1993; Congress has directed that acquisition be restricted to Denali NP\&P. During the 1992 field season, hazardous waste recertification and real-estate appraisal inspections were completed for three patented and three unpatented mining properties in the Kantishna area of Denali NP\&P. These six properties are expected to be purchased in 1993. Late in the 1992 field season, personal property was moved out of the Park from one of the unpatented properties. This relocation was accomplished through a self-move by the claim holders, who were reimbursed under the authority of the Uniform Relocation Assistance and Real Property Acquisition Policies Act.

3. As mandated in Section 1010(b) of ANILCA, the NPS has regulations to authorize AMRAP activities within park units. During 1992, permits were issued to three agencies for seven AMRAP projects in six parks. The USGS worked in Gates of the Arctic NP\&P, Kenai Fjords National Park, Lake Clark National Park, and Noatak National Preserve; the USBM worked in Gates of the Arctic NP\&P, Noatak National Preserve, and Yukon-Charley Rivers National Preserve; and the MMS worked in Katmai National Park. The permits supported USGS AMRAP mapping activities, USBM strategic- and critical-minerals surveys and mining district studies, and the MMS OCS leasing program.

4. Mineral examinations and reports for claim validity were conducted on 11 claim blocks of 55 placer and lode claims in Denali NP\&P. Five validity reports were approved by the BLM for claims in Denali NP\&P.

5. The Abandoned Mineral Lands (AML) Program is designed to manage sites of former mining operations on park lands; its objectives are to eliminate and (or) mitigate safety hazards and to preserve any significant natural or cultural resource values located on the former mining properties. In 1992, one AML site inventory was completed in Glacier Bay NP\&P. AML Reports are in preparation for the Stampede Mine in Denali NP\&P and for AML sites in Wrangell-St. Elias NP\&P.

6. Reclamation research continued in the Kantishna Hills of Denali NP\&P. The ongoing reclamation of an abandoned placer mine is a prototype project designed to study the process of ecosystem recovery. Revegetation studies are evaluating planting techniques, substrata characteristics, the role of soil microorganisms, and species; white spruce and soapberry seedlings were added to revegetation plots in summer 1992. An additional 975 meters of flood plain was recontoured to an engineer-designed 100 year flood plain. Willow plantings and alder berms were installed to protect and stabilize the new flood-plain surface. Research results will be used to guide reclamation planning for plan of operations submissions and reclamation/ stabilization work on mining claims acquired by the NPS. 
7. The Cultural Resources Mining Inventory and Monitoring Program continued to ensure that all miningrelated activities within Alaska's national parks are in full compliance with Federal historic and cultural resource preservation laws and regulations. Field crews conducted surveys in Denali NP\&P, Wrangell-St. Elias NP\&P, and Yukon-Charley Rivers National Preserve, documenting 17 new historic mining sites and two new prehistoric sites. One important discovery was the site of Charley's village, a main settlement of the Han Athabaskans during the early gold-rush days on the Yukon River. Although the village has been cited frequently in ethnographic and historic literature, its actual location had remained a mystery until this discovery.

8. The NPS conducts cadastral surveys to determine the locations of unpatented mining claims and claim boundaries within park units. In 1992, the NPS contracted the BLM to conduct a claim boundary retracement survey for 32 patented claims on Quigley Ridge in Denali NP\&P. In Wrangell-St. Elias NP\&P, a total of 57 unpatented claims were surveyed in the Gold Hill, Dan Creek, and Idaho Gulch areas. Computer-generated plots of these mining claims on 82 0.6-meter-contour topographic map sheets, each containing 1 to 1.5 claims, were received from the contractor and edited by the NPS. These maps are currently used for numerous projects related to minerals and resource management and claim acquisition, including validity examinations, review and analysis of plans of operations, hazardous waste surveys, reclamation projects, and property appraisals. Nearly 3,000 individual computer-generated cartographic, graphic, and engineering products were produced for support of all program areas in Minerals Management, and more than 11 percent of these products were supplied to the private sector, including mining claimants, consultants, concessionaires, and other interested parties.

9. Within the Kantishna Hills area of Denali NP\&P, Moose Creek was surveyed in order to determine its navigability. Conflict arose in 1991 between the State of Alaska and the NPS when the State unilaterally declared sections of the creek navigable, allowed 39 mining claims to be staked, and issued permits for mining operations. In August 1992, the Alaska Department of Natural Resources issued Mineral Order 648, closing to further mineral entry all State lands within Denali NP\&P, but not rescinding the claims already established. An official resolution of navigability status will settle the issue and determine the claims' validity.

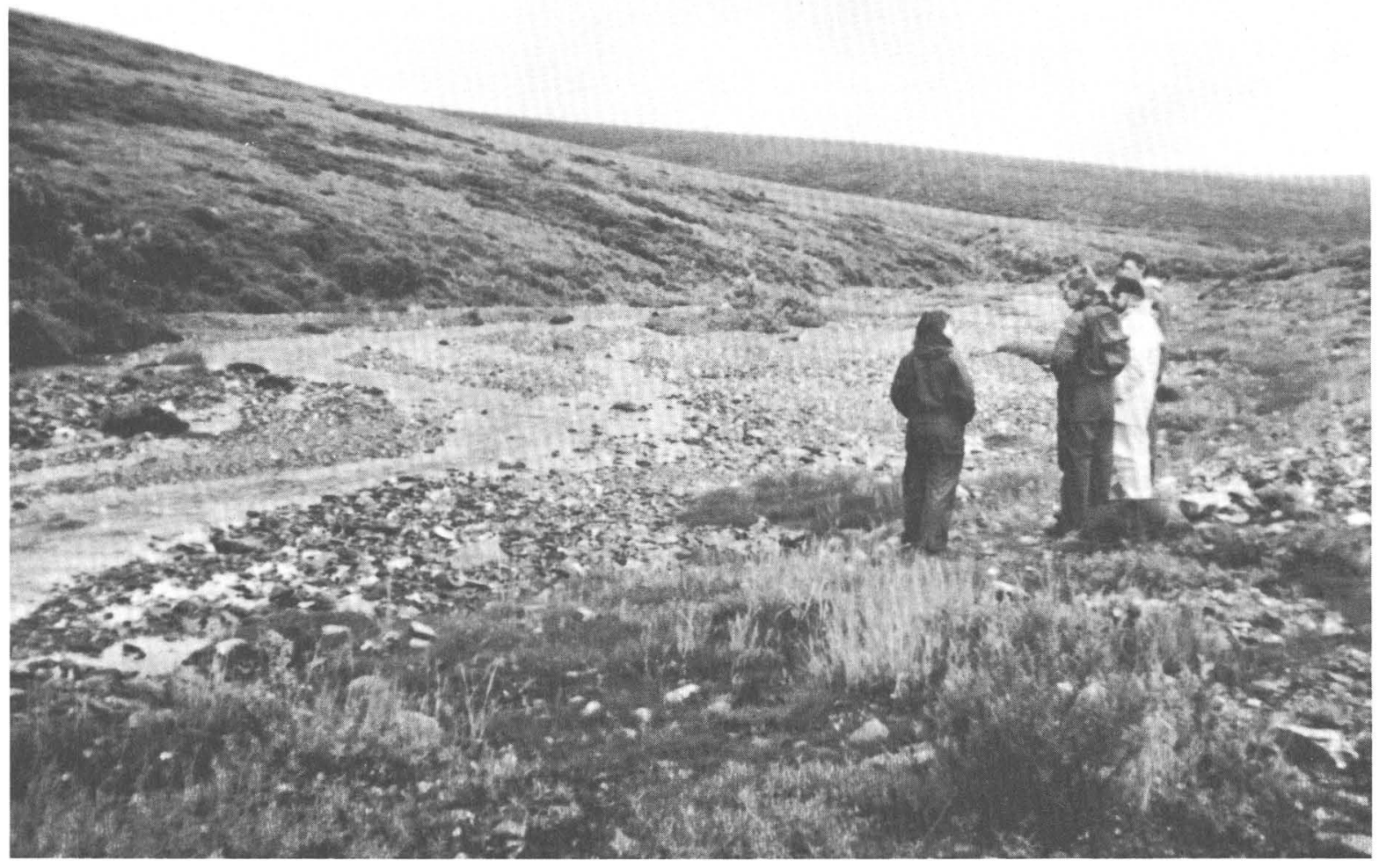

Figure 20. NPS personnel reviewing plan of operations in Bering Land Bridge National Park and Preserve. Photograph provided from NPS files. 


\section{U.S. FOREST SERVICE}

Mineral exploration and development activities on Alaska's National Forest lands are currently in a holding pattern: (1) the Greens Creek Mine shut down in April 1993; (2) Final EIS's have been completed for the Kensington and A-J Mines, but both projects are awaiting permits from various government agencies; and (3) in the Tongass and Chugach National Forests, further action on mineral patent applications on which substantial work has not yet already been accomplished has been suspended due to efforts to revise the 1872 General Mining Law.

\section{TONGASS NATIONAL FOREST}

Management Plan.-The Tongass Timber Reform Act of 1990 (PL 101-626) added 296,080 acres of wilderness to the Tongass National Forest in six new wilderness areas; the 16,737,492-acre National Forest now contains a total of 5,693,246 wilderness acres. The revised Tongass Land Management Plan will incorporate new policies set forth in the Act. One highlight of the Plan revision is a "prescription" for minerals management, designed to encourage and facilitate development of mineral resources; 12 areas in the Tongass National Forest with high mineral potential are identified for the prescription. Publication of the Plan Revision has been delayed pending completion of a peer review by the USFS Pacific Northwest Research Station; the review is focusing on wildlife models, the wildlife viability report, and the rationale used in the report and models for the plan. Depending on the results of the review, the final plan could be published in sometime in 1994.

Greens Creek Mine.-Greens Creek, the largest producing silver mine in the United States, is located in Admiralty Island National Monument, administered by the Tongass National Forest. Discovered in 1974, the deposit's development and production is authorized under ANILCA Section 503(f)(2)(A). The USFS completed a Mine Development EIS for the project in January 1983. The mine was aggressively developed, and production began in January 1989. In March 1990, under the provisions of the 1872 General Mining Law, the Kennecott Greens Creek Mining Company claimed extra-lateral rights based on the geometry of the deposit. Extra-lateral rights allow a company to pursue development of the downward extent of an ore body beyond the vertical boundaries of valid mining claims. The USFS evaluated the claim and recognized the company's assertion of extra-lateral rights in May 1990. In summer 1991, Kennecott Greens Creek Mining filed patent applications for the claims encompassing the mine. The field examination was conducted by USFS mineral examiners, and the BLM issued a patent to 17 lode mining claims and 1 mill-site claim on December 17, 1992. On February 16, 1993, company officials announced the mine's closure due to low metals prices.
Kensington project.-The Kensington gold project, a joint venture between Echo Bay Alaska and Couer Alaska, is located about 40 miles north of Juneau on Lynn Canal. The Record of Decision for the Final EIS on the project was issued by the Forest Supervisor of the Chatham Area of the Tongass National Forest on January 29, 1992. Administrative appeals filed by a variety of individuals in opposition to the Decision were decided in the project's favor. An appeal filed in opposition to the permit was heard before the Assembly of the City and Borough of Juneau on February 20; the Assembly rejected the appeal by unanimous vote. A lawsuit seeking to overturn the Assembly's decision has been filed in Superior Court.

Jualin project.-Geochemical and geophysical studies were conducted on the Jualin project during summer 1992 on USFS, private, and State lands. Gold was originally discovered at the property in 1895; modern claim location and exploration has been in progress since 1980. The Jualin claim block is located adjacent to the Kensington claims, and both projects are prospecting the Jualin shear zone.

Alaska-Juneau project.-The USFS cooperated in the preparation of the EIS for the A-J project, located in Juneau's backyard. Due to its large size and proximity to Juneau, this project is highly controversial. Sheep Creek was identified in the BLM's Final EIS as the preferred alternative for tailings disposal; three other alternatives involve disposal sites on National Forest land. If one of the National Forest alternatives is selected, the USFS would then have to approve the selection, either through a plan of operations or a special-use permit, before any tailings disposal could occur.

Other.-There is a fair amount of minerals activity on Prince of Wales Island in the Tongass National Forest. The USBM is conducting a study of the Ketchikan mining district, and the USGS is compiling data on the mineral resources of southeastern Alaska. In addition to the island's abundant mineral endowment, which ranges from chemical-grade limestone to copper and platinum, the established urban and transportation infrastructure on the island would facilitate the development of those resources. The road system on the island was constructed for harvesting National Forest timber.

\section{CHUGACH NATIONAL FOREST}

During summer 1992, the USGS and USBM conducted minerals field work in the Chugach National Forest in the upper regions of Unakwik Inlet and College Fjord, and in the Copper River Additions between the Copper River delta and the Tasnuna River. The information collected will be used to (1) identify and quantify suspected mineral deposits in the Chugach National Forest, (2) update the Chugach minerals data base of known mineral occurrences, (3) identify potential opportunities for mineral 
development, and (4) protect access and predict the extent of mineral development during the planning period for the pending Forest Plan revision.

Abandoned mine sites in the Chugach National Forest are being inventoried by the USFS and USBM for chemical and physical safety hazards that may have resulted from past mining activities (fig. 21). The USBM is providing field and technical assistance for this investigation through a partnership agreement with the Chugach National Forest. During 1992, personnel documented hazards at 17 sites and collected samples to test for possible soil contamination. Mitigation and remediation measures for previously identified hazards were initiated.

\section{INDUSTRIAL MINERALS}

\section{OVERVIEW OF INDUSTRY ACTIVITY}

In 1992, the production of sand, gravel, and building stone remained at about the same levels as for the last 6 years; approximately 13.2 million metric tons of sand and gravel, valued at $\$ 42.2$ million, and 2.6 million metric tons of building stone were quarried (table 6) (Swainbank and others, 1993). Oddly enough, the value of jade and soapstone skyrocketed 150 percent, even while production plummeted from 14.5 to 1.4 metric tons.

\section{ACTIVITY BY FEDERAL AGENCIES}

\section{BUREAU OF LAND MANAGEMENT}

The disposal of salable mineral materials, namely sand and gravel, continued to be a minor activity for the BLM in Alaska.

\section{U.S. FISH AND WILDLIFE SERVICE}

When compatible with refuge purposes, the FWS issues special-use permits for the sale and extraction of sand and gravel to support development activities in rural communities. In 1992, the Izembek NWR sold gravel at Cold

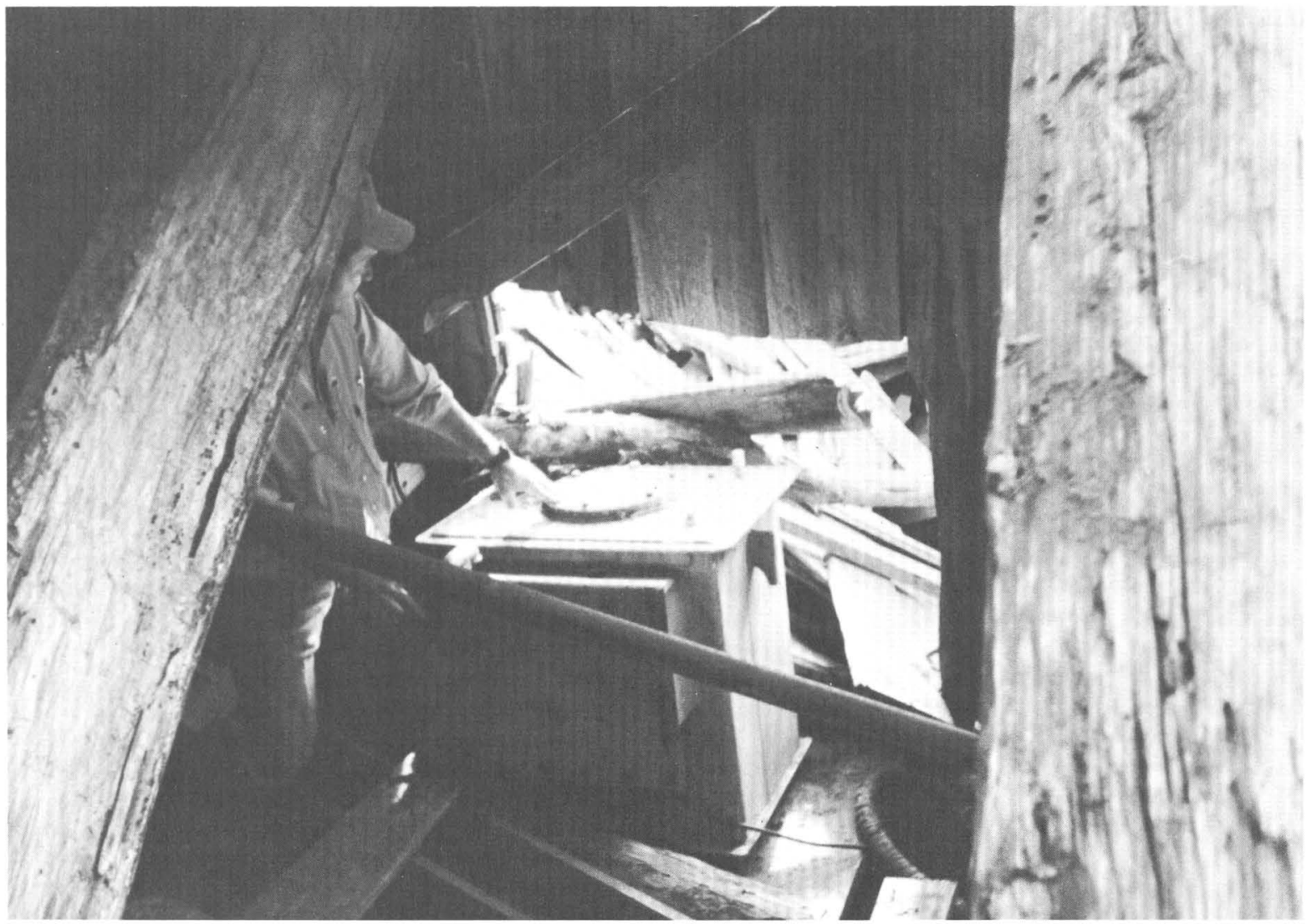

Figure 21. USBM scientist inspects oil-filled electrical transformer at an abandoned mine in the Chugach National Forest. Environmental damage may result if oil from abandoned equipment leaks into the underlying soil and groundwater. Photograph by C. Huber. 
Bay and False Pass. The Aleutian Islands Unit, Alaska Maritime NWR, began processing an application for a gravel sale at Atka.

\section{U.S. FOREST SERVICE}

Annually, the USFS permits the removal of many thousands of tons of sand, gravel, and stone from National Forest lands. Much of this material is used in the construction of timber-sale roads. Lesser amounts are used by State and local governments for the construction and maintenance of breakwaters, airports, and roads.

Large reserves of high quality sand and gravel occur in the Portage Valley, within the Glacier Ranger District of the Chugach National Forest, 50 miles south of Anchorage. Gravel extraction sites on USFS land in the Portage Valley are the primary source for aggregate in the Girdwood area. Extraction sites are reclaimed mainly for fish enhancement.

\section{REFERENCES CITED}

Affolter, R.H., and Stricker, G.D., 1987, Variations in element distribution of coal from the Usibelli Mine, Healy, Alaska, in Rao, P.D., ed., Focus on Alaska's Coal '86, Conference proceedings: University of Alaska at Fairbanks, Mineral Industry Research Laboratory Report 72, p. 91-99.

Alaska Business Monthly [published monthly by Alaska Business Publishing Company, Box 241288, Anchorage, Alaska 99524-1288].

Alaska Journal of Commerce [published weekly by OCA Publishing, 3710 Woodland Drive, Suite 2100, Anchorage, AK 99517].

Alaska Miner, 1992, News in brief-Fort Knox update: Alaska Miner, v. 20, no. 10 , p. 12.

Alaska Oil and Gas Conservation Commission Bulletin [published monthly by the State of Alaska, Alaska Oil and Gas Conservation Commission, 3001 Porcupine Drive, Anchorage, AK 99501].

Alaska Report [published weekly by Petroleum Information Corporation, P.O. Box 102278, Anchorage, AK 99510].

American Society for Testing and Materials, 1980, Standard for metric practice: Philadelphia, Pennsylvania, American Society for Testing and Materials, E380-79 [PCN 06-503807-41], 42 p.

Anchorage Daily News [published daily by Anchorage Daily News Incorporated, 1001 Northway Drive, Anchorage, AK 99508].

Anchorage Times [published daily by Anchorage Times Publishing Company, 820 West Fourth Avenue, Anchorage, AK 99501-now defunct].

Baer, R.L., Sherman, G.E., and Plumb, P.D., 1992, Submarine tailings disposal of mill tailings from on-land sources-An overview and bibliography: U.S. Bureau of Mines OpenFile Report 89-92, 102 p.

Bradley, D.C., and Dusel-Bacon, C., eds., 1992, Geologic studies in Alaska by the U.S. Geological Survey, 1991: U.S. Geological Survey Bulletin 2041, 256 p.
Brew, D.A., 1992, Decision points and strategies in quantitative probabilistic assessment of undiscovered mineral resources: U.S. Geological Survey Open-File Report 92-307, 21 p.

Brew, D.A., Drew, L.J., Schmidt, J.M., Root, D.H., Huber, D.F., and Drinkwater, J.L., 1992, Firsthand USGS-Alaskan Branch experience with probabilistic assessment of undiscovered mineral resources-The Tongass National Forest and adjacent areas, southeastern Alaska [abs.], in Mineral potential workshop-Report of proceedings: British Columbia Ministry of Energy, Mines, and Petroleum Resources, Geological Survey Branch Information Circular 1992-22, p. 17-18.

Bundtzen, T.K., Swainbank, R.C., Wood, J.E., and Clough, A.H., 1992, Alaska's mineral industry 1991: Alaska Division of Geological and Geophysical Surveys Special Report $46,89 \mathrm{p}$.

Carlson, P.R., and Kvenvolden, K.A., 1993, Tracking Exxon Valdez oil from beach to deep-water sediments of Prince William Sound, Alaska: [in press].

Chandler, B., and Middaugh, J.P., 1992, Health risk assessment of radioisotopes at Cape Thompson, Alaska: Anchorage, Alaska, State of Alaska Department of Health and Social Services, $10 \mathrm{p}$.

Chenowith, W.L., 1992, State of the U.S. uranium industry in 1992, in Association Round Table: American Association of Petroleum Geologists Bulletin, v. 76, no. 9, p. 1451-1452.

Clough, J.G., Patton, P.C., and Christiansen, A.C., eds., 1987, Arctic National Wildlife Refuge, Alaska, coastal plain resource assessment-Report and recommendation to the Congress of the United States and final legislative environmental impact statement: Washington, DC, U.S. Fish and Wildlife Service, U.S. Geological Survey, and Bureau of Land Management, 2 v., 208 p.

Clough, J.G., Robinson, M.S., Decker, J., and O'Sullivan, P.B., 1990, Bedrock geology of the Sadlerochit and Shublik Mountains and apatite fission-track thermal history of Permian to Tertiary sedimentary rocks in the Arctic National Wildlife Refuge, northeastern Alaska, in Hunt, M.C., Doenges, S., and Stubbs, G.S. eds., Second Symposium on Studies Related to Continental Margins-A summary of year-three and year-four activities: Austin, University of Texas, Bureau of Economic Geology, p. 18-24.

Coal News [published weekly by National Coal Association, 1130 17th Street N.W., Washington, DC 20036].

Cooke, L.W., 1991, Estimates of undiscovered, economically recoverable oil and gas resources for the Outer Continental Shelf, revised as of January 1990: Minerals Management Service OCS Report MMS 91-0051, 30 p.

Crowe, D.E., Nelson, S.W., Brown, P.E., Shanks III, W.C., and Valley, J.W., 1992, Geology and geochemistry of volcanogenic massive sulfide deposits and related igneous rocks, Prince William Sound, south-central Alaska: Economic Geology, v. 87, no. 7, p. 1722-1746.

Csejtey, Bela, Jr., and Keith, W.J., 1992, Preassessment report on the Holy Cross quadrangle, Alaska: U.S. Geological Survey, Administrative Report, $52 \mathrm{p}$.

Daniel, L.M., 1992, The Tongass-Getting beneath the surface: U.S. Bureau of Mines Minerals Today, August 1992, p. 12-17.

Dusel-Bacon, Cynthia, 1991, Metamorphic history of Alaska: U.S. Geological Survey Open-File Report 91-556, 48 p., 2 sheets, scale $1,000,000$. 
Fairbanks Daily News-Miner [published 6 days a week by the Fairbanks Publishing Company, 200 North Cushman, Fairbanks, AK 99701].

Finley, P., and Krason, J., 1989, Evaluation of geological relationships to gas hydrate formation and stability-Summary Report, v. 15 of Geological evolution and analysis of confirmed or suspected gas hydrate localities: Department of Energy/Morgantown Energy Technology Center, DOE/MC/ 21181-1950 (NTIS DE90000452), $111 \mathrm{p}$.

Gamble, B.M., and Till, A.B., 1993, Metallic mineral resources of the Bendeleben and Solomon quadrangles, western Alaska: U.S. Geological Survey Miscellaneous Field Studies MF-1838-D, 3 sheets, scale 1:250,000.

Glenn, R., and Allen, W.W., 1992a, Geology, reservoir engineering, and methane-hydrate potential of the Walakpa gas field, North Slope, Alaska: Department of Energy/ Morgantown Energy Technology Center, DOE/MC/281313334 (NTIS DE93000271), 26 p.

1992b, The development of a shallow gas field in the Arctic-The Walakpa field, North Slope, Alaska [abs.]: International Conference on Arctic Margins, Anchorage, Alaska, 1992, ICAM Abstracts, p. 20.

Kelley, J.S., Tailleur, I.L., Morin, R.L., Reed, K.M., Harris, A. G., Schmidt, J.M., Brown, F.M., and Kurtak, J.M., 1993, Barite deposits in the Howard Pass quadrangle and possible relations to barite elsewhere in the northwestern Brooks Range, Alaska: U.S. Geological Survey Open-File Report 93-215, 13 p., 9 sheets.

Kelley, K.D., Borden, J.C., Bailey, E.A., Fey, D.L., Motooka, J.M., and Roushey, B.H., 1992, Geochemically anomalous areas in the west-central part of the Howard Pass quadrangle, National Petroleum Reserve, Alaska-Evidence for sediment-hosted $\mathrm{Zn}-\mathrm{Pb}-\mathrm{Ag}-\mathrm{Ba}$ mineralization: U.S. Geological Survey Bulletin 2041, p. 60-69.

Kirschner, C.E., 1988, Map showing sedimentary basins of onshore and continental shelf areas, Alaska: U.S. Geological Survey Miscellaneous Investigations Series Map I-1873, one sheet, scale $1: 2,500,000$.

Krason, J., and Ciesnik, M., 1987, Basin analysis, formation, and stability of gas hydrates of the Aleutian Trench and the Bering Sea, v. 10 of Geological evolution and analysis of confirmed or suspected gas hydrate localities: Department of Energy/Morgantown Energy Technology Center, DOE/ MC/21181-1950 (NTIS DE88001008), $152 \mathrm{p}$.

Krason, J., and Finley, P., 1989, Basin analysis, formation, and stability of gas hydrates in the Beaufort Sea, v. 12 of Geological evolution and analysis of confirmed or suspected gas hydrate localities: Department of Energy/Morgantown Energy Technology Center, DOE/MC/21181-1950 (NTIS DE90000431), $227 \mathrm{p}$.

Kvenvolden, K.A., Hostettler, F.D., Rapp, J.B., and Carlson, P.R., 1993, Hydrocarbon in oil residues on beaches of islands of Prince William Sound, Alaska: Marine Pollution Bulletin [in press].

Lange, I.M., Nokleberg, W.J., Newkirk, S.R., Aleinikoff, J.N., Church, S.E., and Krouse, H.R., 1993, Devonian volcanogenic massive sulfide deposits and occurrences, southern Yukon-Tanana terrane, eastern Alaska Range, Alaska: Economic Geology [in press].

Leonard, K.R., and Huber, D.F., 1987, Status of Alaska Mineral
Resources Data System, in Hamilton, T.D., and Galloway, J.P., eds., Geologic studies in Alaska by the U.S. Geological Survey during 1986: U.S. Geological Survey Circular 998 , p. $15-18$.

Loney, R.A., and Himmelberg, G.R., 1992, Petrogenesis of the Pd-rich intrusion at Salt Chuck, Prince of Wales IslandAn early Paleozoic Alaskan-type ultramafic body: Canadian Mineralogist, v. 30, pt. 4, p. 1005-1022.

Malone, R.D., 1990, Gas hydrates-Technology status report: U.S. Department of Energy, DOE/METC-90/0270 (NTIS DE90015321), $52 \mathrm{p}$.

Mast, R.F., Dolton, G.L., Crovelli, R.A., Root, D.H., and Attanasi, E.D., U.S. Geological Survey; Martin, P.E., Cooke, L.W., Carpenter, G.B., Pecora, W.C., and Rose, M.B., Minerals Management Service, 1989, Estimates of undiscovered conventional oil and gas resources in the United States-A part of the Nation's energy endowment: U.S. Department of the Interior, $44 \mathrm{p}$.

McDowell Group, 1992, The economic impact of the mining industry in southeast Alaska: U.S. Bureau of Mines OpenFile Report 87-92, 40 p.

Minerals Management Service, 1990, Alaska regional studies plan (Final, FY 1991-1992): U.S. Department of the Interior, Minerals Management Service, Alaska OCS Region, Anchorage, Alaska, $141 \mathrm{p}$.

1992, Comprehensive program 1992-1997-Summary and decision: U.S. Department of the Interior, Minerals Management Service, Alaska OCS Region, Anchorage, Alaska, 38 p. + appendices.

Mining Journal [published weekly by The Mining Journal Limited, P.O. Box 10, Edenbridge, Kent TN8 5NE, England].

Newcomer, E.S., and McDevitt, P.G., 1992, TAPS reroute meets schedule, beats cost estimate: Oil and Gas Journal, v. 90, no. 37 , p. $49-57$.

Northern Miner [published weekly by Northern Miner Press Limited, 7 Labatt Avenue, Toronto, ON M5A 3P2, Canada].

Odell, R.D., 1992, North American uranium activity: Rocky Mountain Scout, Casper, Wyoming, R.D. 24 p.

O'Sullivan, P.B., 1988, Apatite fission-track study of the thermal history of Permian to Tertiary sedimentary rocks in the Arctic National Wildlife Refuge, northeastern Alaska: Fairbanks, University of Alaska, M.Sc. thesis, 184 p.

O'Sullivan, P.B., Decker, J.E., and Bergman, S.C., 1989, Apatite fission-track study of the thermal history of Permian to Tertiary sedimentary rocks in the Arctic National Wildlife Refuge, northeastern Alaska [abs.]: Geological Society of America Abstracts with Programs, v. 21, p. 126.

Piper, A.M., 1966, Potential effects of Project Chariot on local water supplies, northwestern Alaska: U.S. Geological Survey Professional Paper 539, 45 p., 2 sheets, scales $1: 500,000$ and $1: 12,000$.

Pittsburgh Energy Technology Center, 1992, Draft environmental impact statement for the proposed Healy Clean Coal Project: Pittsburgh Energy Technology Center, DOE/EIS0186, $200 \mathrm{p}$.

Pool, T.C., 1992, Uranium-Is the worst over?: Mining and Engineering Journal, v. 193, no. 4, p. 45-47.

Rintoul, Bill, 1993, Alaska drilling and production: Pacific Oil World, v. 85 , no. 1 , p. $52-57$. 
Stricker, G.D., 1991, Economic Alaskan coal deposits, in Gluskoter, H.J., Rice, D.D., and Taylor, R.B., eds., Economic geologyU.S., v. P-2 of Geology of North America: Boulder, Colorado, Geological Society of America, Decade of North American Geology series, p. 591-602.

Swainbank, R.C., Bundtzen, T.K., Clough, A.H., and Hansen, E.W., 1993, Alaska's mineral industry 1992-A summary: Alaska Division of Geological and Geophysical Surveys Information Circular 36, $11 \mathrm{p}$.

Till, A.B., Dumoulin, J.A., Gamble, B.M., Kaufman, D.S., and Carroll, P.I., 1986, Preliminary geologic map and fossil data, Solomon, Bendeleben, and southern Kotzebue quadrangles, Seward Peninsula, Alaska: U.S. Geological Survey Open-File Report 86-276, 69 p., 3 sheets, scale 1:250,000.

U.S. Department of Transportation-Office of Pipeline Safety, Bureau of Land Management, and State of Alaska, 1992, Corrosion protection monitoring of the Trans-Alaska Pipeline System, Final Report: Bureau of Land Management BLM-AK-PT-93-013-1816-983, 63 p.

Warner, J.D., and Barker, J.C., 1989, Columbium- and rareearth-element-bearing deposits at Bokan Mountain, southeast Alaska: U.S. Bureau of Mines Open-File Report 33-89, $196 \mathrm{p}$.

Wells, Ken, compiler, 1992, The Kensington gold project, southeast Alaska: Alaska Geology, v. 21, no. 8, p. 1, 7.

\section{APPENDIX 1.-ALASKA MINERAL REPORTS RELEASED DURING 1992 AND EARLY 1993}

The following selected publications contain pertinent information about energy resources and other minerals in Alaska released during 1992 or early 1993; these are in addition to the reports listed in the section entitled "References Cited." This listing is only a selection of relevant reports from the publications of any agency. Reports by Federal or State agencies can generally be obtained from the agency offices in Alaska, or are available at the Alaska Resources Library, Federal Building, 701 C Street, Anchorage, AK 99513-7599.

The USGS publishes a monthly listing of its own releases, "New Publications of the U.S. Geological Survey," available free from the U.S. Geological Survey, 582 National Center, Reston, VAA 22092. These listings are also compiled into an annual volume, "Publications of the U.S. Geological Survey, 1992." Information about the prices and sources of listed reports is given in these two publications and is also available from the USGS Earth Science Information Centers.

The USBM's central distribution office is the Branch of Production and Distribution, 4800 Forbes Avenue, Pittsburgh, PA 15213. Many USBM reports are available from the U.S. Government Printing Office in Washington, D.C., or from the National Technical Information Service (NTIS) in Springfield, VA 22161. USBM reports listed here are available from the USBM library in Juneau; for further information, contact the Chief, Alaska Field Operations Center, 3301 C Street, Suite 525, Anchorage, AK 99503.

MMS publications may also be purchased from NTIS, which issues listings of all available MMS volumes. A limited number of complimentary reports are available at the MMS Library/Public Information Room, Alaska OCS Region, Minerals Management Service, 949.East 36th Avenue, Room 603, Anchorage, AK 99508-4302; phone (907) 271-6439.

\section{DEPARTMENT OF THE INTERIOR}

\section{U.S. GEOLOGICAL SURVEY}

List includes Federal and non-Federal publications by USGS authors:

Adams, D.D., Freeman, C.J., Goldfarb, R.J., Gent, C.A., and Snee, L.W., 1992, Age and geochemical constraints on mesothermal gold mineralization, Valdez Creek district, Alaska [abs.]: Geological Society of America Abstracts with Programs, v. 24, no. 5, p. 2.

Apodaca, L.E., 1992, Fluid-inclusion study of the Rock Creek area, Nome mining district, Seward Peninsula, Alaska: U.S. Geological Survey Bulletin 2041, p. 3-12.

Attanasi, E.D., Bird, K.J., and Mast, R.F., 1993, Economics and the national oil and gas assessment-The case of onshore northern Alaska: American Association of Petroleum Geologists Bulletin, v. 77, no. 3, p. 491-504.

Beaudoin, B.C., Fuis, G.S., Mooney, W.D., Nokleberg, W.J., and Christensen, N.I., 1992, Thin, low-velocity crust beneath the southern Yukon-Tanana terrane, east-central Alaska: Results from Trans-Alaska Crustal Transect refraction/wide-angle reflection data: Journal of Geophysical Research, v. 97, p. 1921-1942.

Beyer, L.A., 1992, Petroleum reservoir evaluation by borehole gravity survey [abs.]: U.S. Geological Survey Circular 1074 , p. $3-4$.

Bird, K.J., 1993a, Arctic Coastal Plain province (058): U.S. Geological Survey Bulletin 2034A [in press].

1993b, Northern Foothills province (059): U.S. Geological Survey Bulletin 2034A [in press].

1993c, Southern Foothills-Brooks Range province (060): U.S. Geological Survey Bulletin 2034A [in press].

1993d, The Ellesmerian petroleum system, North Slope of Alaska, USA, in Magoon, L.B., and Dow, W., eds., American Association of Petroleum Geologists [in press].

Bird, K.J., and Collett, T.S., 1992, Sagavanirktok Formation-A new look with seismic data in the Prudhoe Bay-Kuparuk River region, Alaskan North Slope [abs.]: U.S. Geological Survey Circular 1074, p. 7.

Bird, K.J., Howell, D.G., Johnsson, M.J., and Magoon, L.B., 1992, Alaskan North Slope geothermics, geodynamics, and hydrology-Implications for oil and gas [abs.]: U.S. Geological Survey Circular 1074, p. 8.

Bird, K.J., Johnsson, M.J., Howell, D.G., and Magoon, L.B., 1992, Thermal maturity mapping in Alaska: U.S. Geological Survey Yearbook, Fiscal Year 1991, p. 55-57.

Bird, K.J., and Molenaar, C.M., 1992, The North Slope foreland basin, Alaska, in Macqueen R.W., and Leckie, D.A., eds., Foreland basins and foldbelts: American Association of Petroleum Geologists Memoir 55, p. 363-393.

Bliss, J.D., 1992, Grade and tonnage model of Chugach-type lowsulfide Au-quartz veins: U.S. Geological Survey Bulletin 2004 , p. $44-46$. 
Bohn, Diedra, and Schneider, J.L., 1992, 1992 annual report on Alaska's mineral resources: U.S. Geological Survey Circular 1091, $65 \mathrm{p}$.

Borden, J.C., Goldfarb, R.J., Gent, C.A., Burruss, R.C., and Roushey, B.H., 1992, Geochemistry of lode-gold deposits, Nuka Bay district, southern Kenai Peninsula: U.S. Geological Survey Bulletin 2041, p. 13-22.

Bradley, D.C., and Dusel-Bacon, C., eds., 1992, Geologic studies in Alaska by the U.S. Geological Survey, 1991: U.S. Geological Survey Bulletin 2041, 256 p.

Brew, D.A., Drew, L.J., and Ludington, S.D., 1992, The study of the undiscovered mineral resources of the Tongass National Forest and adjacent lands, southeastern Alaska: Nonrenewable Resources, v. 1, no. 4, p. 303-322.

Briggs, P.H., Motooka, J.M., Bailey, E.A., Cieutat, B.A., Burner, S.A., Kelley, K.D., and Ficklin, W.H., 1992, Analytical results of soil, stream sediment, panned concentrate, and water samples from the Lik deposit, northwestern Brooks Range, Alaska: U.S. Geological Survey Open-File Report 92-015A, 55 p.

Brouwers, Elisabeth M., 1992, Pliocene paleoecologic reconstructions based on ostracode assemblages from the Sagavanirktok and Gubik formations, Alaskan North Slope: U.S. Geological Survey Open-File Report 92-321, 49 p.

Bruns, T.R., 1993a, Gulf of Alaska province (069): U.S. Geological Survey Bulletin 2034A [in press].

1993b, Southeastern Alaska province (071): U.S. Geological Survey Bulletin 2034A [in press].

Bruns, T.R., Stevenson, A.J., and Dobson, M.R., 1992, GLORIA investigation of the Exclusive Economic Zone in the Gulf of Alaska and off southeast Alaska-M/V Farnella cruise F7-89-GA, June 14-July 13, 1989: U.S. Geological Survey Open-File Report 92-317, 16 p.

Bundtzen, T.K., and Miller, M.L., 1992, Petrology and metallogeny of Late Cretaceous-early Tertiary igneous rocks, Kuskokwim Mountains, southwest Alaska [abs.]: Geological Society of America Abstracts with Programs, v. 24 , no. 5 , p. 11 .

Burns, L.E., 1992, Ophiolitic complexes and associated rocks near the Border Ranges fault zone, south-central Alaska: U.S. Geological Survey Open-File Report 92-020E, 8 p., 1 plate.

Carter, L.M.H., ed., 1992, USGS research on energy resources, 1992-Program and abstracts-Eighth V.E. McKelvey forum on mineral and energy resources: U.S. Geological Survey Circular 1974, $89 \mathrm{p}$.

Cathrall, J.B., VanTrump, G., Jr., Antweiler, J.C., and Mosier, E.L., 1992, Magnetic media file of analytical results and geochemical signatures of lode gold, placer gold, and heavy-mineral concentrates from mining districts in central, western, and northern Alaska: U.S. Geological Survey Open-File Report 92-573, 17 p.

Church, S.E., Riehle, J.R., Magoon, L.B., and Campbell, D.L., 1992, Mineral and energy resource assessment maps of the Mount Katmai, Naknek, and western Afognak quadrangles, Alaska: U.S. Geological Survey Miscellaneous Field Studies Map MF-2021-F, 22 p., 2 sheets, scale 1:250,000.

Cieutat, B.A., Goldfarb, R.J., Bradley, D.C., and Roushey, B.H., 1992, Placer gold of the Kenai lowland: U.S. Geological Survey Bulletin 2041, p. 23-29.

Collett, T.S., 1992a, Natural gas hydratesa proven resource [abs.]: U.S. Geological Survey Circular 1074, p. 14-15.

1992b, Potential of gas hydrates outlined: Oil and Gas Journal, v. 90, no. 29, p. 84-87.

1992c, Well log evaluation of natural gas hydrates: U.S. Geological Survey Open-File Report 92-381, 37 p.

1993, Natural gas hydrates of the Prudhoe Bay and Kuparuk River area, North Slope, Alaska: American Association of Petroleum Geologists Bulletin, v. 77, no. 5, p. 793-812.

Crock, J.G., Gough, L.P., Mangis, D.R., Curry, K.L., Fey, D.L., Hageman, P.L., and Welsch, E.P., 1992, Element concentrations and trends for moss, lichen, and surface soils in and near Denali National Park and Preserve, Alaska: U.S. Geological Survey Open-File Report 92-323, 156 p.

Csejtey, Bela, Jr., Mullen, M.W., Cox, D.P., and Stricker, G.D., 1992, Geology and geochronology of the Healy quadrangle, south-central Alaska: U.S. Geological Survey Miscellaneous Investigations Series Map I-1961, 63 p., 2 sheets, scale $1: 250,000$.

Deming, David, J.H. Sass, and A.H. Lachenbruch, 1992, Heat flow and subsurface temperature as evidence for basin-scale groundwater flow, North Slope of Alaska: Geological Society of America Bulletin, v. 104, no. 5, p. 528-542.

Detra, D.E., Motooka, J.M., and Cathrall, J.B., 1992, Supplemental analytical results and sample locality map of streamsediment and heavy-mineral concentrate samples from the Craig study area, Craig, Dixon Entrance, Ketchikan, and Prince Rupert quadrangles, Alaska: U.S. Geological Survey Open-File Report 92-552, 17 p., 1 sheet, scale 1:250,000, one $5 \frac{1}{4}$ " diskette.

Dickinson, K.A., and Skipp, G.L., 1992, Clay mineral depositional facies and uranium resource potential in part of the Tertiary Kenai Group, Kenai Peninsula, Alaska: U.S. Geological Survey Bulletin 1999, p. 81-99.

Dolton, G.L., Mast, R.F., and Crovelli, R.A., 1992, Undiscovered oil and gas resources of Federal lands and waters [abs.]: U.S. Geological Survey Circular 1974, p. 21-22.

Dover, J.H., 1992, Geologic map and fold-and-thrust-belt interpretation of the southeastern part of the Charley River quadrangle, east-central Alaska: U.S. Geological Survey Miscellaneous Investigations Map I-1942, scale 1:100,000.

Dumoulin, J.D., and Harris, A.G., 1992, Devonian-Mississippian carbonate sequence in the Maiyumerak Mountains, western Brooks Range, Alaska: U.S. Geological Survey Open-File Report 92-003, 87 p.

Dusel-Bacon, Cynthia, 1991, Metamorphic history of Alaska: U.S. Geological Survey Open-File Report 91-556, 48 p., 2 sheets, scale $1,000,000$.

Fisher, M.A., 1993a, Hope Basin province (065): U.S. Geological Survey Bulletin 2034A [in press].

1993b, Kodiak Island province (070): U.S. Geological Survey Bulletin 2034A [in press].

Fisher, M.A., Nokleberg, W.J., Labson, V.F., Brocher, T.M., Geist, E.L., and Stanley, W.D., 1993, Crustal structure of the eastern Alaska Range orogen and the strike-slip Denali fault, Alaska-An integrated interpretation of geologic, magnetotelluric, and seismic reflection data: Journal of Geophysical Research [in press].

Flores, R.M., and Stricker, G.D., 1993a, Reservoir framework architecture in the type Clamgulchian (Pliocene) Sterling Formation, Kenai Peninsula, Alaska, in Dusel-Bacon, 
Cynthia, and Till, A.B., eds., Geologic studies in Alaska by the U.S. Geological Survey, 1992: U.S. Geological Survey Bulletin [in press].

-1993b, Early Cenozoic depositional systems, Wishbone Hill District, Matanuska coal field, Alaska in Dusel-Bacon, Cynthia, and Till, A.B., eds., Geologic studies in Alaska by the U.S. Geological Survey, 1992: U.S. Geological Survey Bulletin [in press].

Foley, J.Y., 1992, Ophiolitic and other mafic-ultramafic metallogenic provinces in Alaska (west of the 141st meridian): U.S. Geological Survey Open-File Report 92-020B, 57 p., 1 sheet, scale 1:250,000.

Folger, P.F., Goldfarb, R.J., and Cieutat, B.A., 1992, Geochemical survey of the Baird Mountains $1^{\circ} \times 3^{\circ}$ quadrangle: U.S. Geological Survey Bulletin 2003, 77 p., 1 sheet, scale $1: 250,000$.

Foster, H.L., 1992, Geologic map of the eastern Yukon-Tanana region, Alaska: U.S. Geological Survey Open-File Report 92-313, 27 p., 1 sheet, scale 1:500,000.

Frisken, J.G., and Arbogast, B.F., 1992a, Map showing the distribution of anomalous concentrations of selected elements determined in stream sediments from the Port Moller, Stepovak Bay, and Simeonof Island quadrangles, Alaska Peninsula, Alaska: U.S. Geological Survey Miscellaneous Field Studies Map MF-2155-B, 1 sheet, scale 1:250,000.

-1992b, Maps showing the distribution of anomalous concentrations of selected elements and minerals determined in nonmagnetic heavy-mineral concentrates from the Port Moller, Stepovak Bay, and Simeonof Island quadrangles, Alaska Peninsula, Alaska: U.S. Geological Survey Miscellaneous Field Studies Map MF-2155-C, 3 sheets, scale $1: 250,000$.

Frisken, J.G., and Kelly, D.L., 1992, Maps showing the distribution of gold determined in various sample media collected from the Port Moller, Stepovak Bay, and Simeonof Island quadrangles, Alaska Peninsula, Alaska: U.S. Geological Survey Miscellaneous Field Studies Map MF-2155-D, 2 sheets, scale 1:250,000.

Frost, G.M., and Stanley, R.G., 1991, Compiled geologic and Bouguer gravity map of the Nenana basin area, central Alaska: U.S. Geological Survey Open-File Report 91-562, 30 p., 2 oversized sheets, scale 1:250,000.

Frost, T.P., 1992, Analytical results in digital format of rock samples from the Bethel and part of the Russian Mission $1^{\circ}$ $\times 3^{\circ}$ quadrangles, Alaska: U.S. Geological Survey OpenFile Report 92-582, 6 p., one 3a" diskette.

Frost, T.P., Bailey, E.A., Bradley, L., O'Leary, R., and Motooka, J., 1992a, Analytical results of stream-sediment samples from the Bethel and southern part of the Russian Mission $1^{\circ} \times 3^{\circ}$ quadrangles, southwest Alaska: U.S. Geological Survey Open-File Report 92-379, 119 p.

1992b, Analytical results of non-magnetic heavy-mineralconcentrate sample data from the Bethel and part of the Russian Mission $1^{\circ} \times 3^{\circ}$ quadrangles, southwest Alaska: U.S. Geological Survey Open-File Report 92-380, 98 p.

Frost, T.P., Box, S.E., and Moll-Stalcup, E.J., 1992, Summary of results of the mineral resource assessment of the Bethel and southeastern part of the Russian Mission $1^{\circ} \times 3^{\circ}$ quadrangles, Alaska: U.S. Geological Survey Bulletin 2041, p. 13-22.
Frost, T.P., Bradley, L.A., O'Leary, R., \& Motooka, J., 1992, Analytical results, sample locality map, and descriptions of rock samples from the Bethel and southern part of the Russian Mission $1^{\circ} \times 3^{\circ}$ quadrangles, southwest Alaska: U.S. Geological Survey Open-File Report 92-315, 229 p, 1 sheet, scale 1:250,000.

Gault, H.R., and Wahrhaftig, C., 1992, The Salt Chuck copperpalladium mine, Prince of Wales Island, southeastern Alaska: U.S. Geological Survey Open-File Report 92-293, $10 \mathrm{p}$.

Gehrels, G.E., and Berg, H.C., 1992, Geologic map of southeastern Alaska: U.S. Geological Survey Miscellaneous Investigations Map I-1867, scale 1:600,000.

Goldfarb, R.J., Case, J.E., Plafker, G., and Winkler, G.R., 1992, Maps showing area of potential mineral resources in the Cordova and northern Middleton Island $1^{\circ} \times 3^{\circ}$ quadrangles, southern Alaska: U.S. Geological Survey Miscellaneous Field Studies MF-2190, scale 1:250,000.

Goldman, M.R., Fuis, G.S., Luetgert, J.H., and Geddes, D.J., 1992, Data report for the TACT 1987 refraction surveyFairbanks North and Olnes deployments: U.S. Geological Survey Open-File Report 92-196, 98 p.

Gray, J.E., Adrian, B.M., Hageman, P.L., and Kilburn, J.E., 1992, Analytical results and sample locality maps of rock samples from the eastern Goodnews Bay quadrangle, southwest Alaska: U.S. Geological Survey Open-File Report 92-008, $23 \mathrm{p}$.

Gray, J.E., Goldfarb, R.J., Snee, L.W., and Gent, C.A., 1992, Geochemical and temporal conditions for the formation of mercury-antimony deposits, southwestern Alaska [abs.]: Geological Society of America Abstracts with Programs, v. 24 , no. 5 , p. 28.

Gray, J.E., Hageman, P.L., and Ryder, J.L., 1992, Comparison of the effectiveness of stream-sediment, heavy-mineral-concentrate, aquatic-moss, and stream-water geochemical sample media for the mineral assessment study of the Iditarod quadrangle, Alaska: U.S. Geological Survey Bulletin 2041, p. 49-59.

Howe, D.L., Streveler, G.P., and Brew, D.A., 1992, Bibliography of research and exploration in the Glacier Bay region, southeastern Alaska, 1798-1991: U.S. Geological Survey Open-File Report 92-596, 70 p.

Howell, D.G., 1992, Collisional tectonics and the global generation of oil and gas [abs.]: U.S. Geological Survey Circular 1074 , p. 36-37.

Howell, D.G., Bird, K.J., Lu, H., and Johnsson, M.J., 1992, Tectonics and petroleum potential of the Brooks Range fold and thrust belt-A progress report: U.S. Geological Survey Bulletin 1999, p. 112-126.

Howell, D.G., Johnsson, M.J., Underwood, M.B., Lu, H., and Hillhouse, J.W., 1992, Tectonic evolution of the Kandik region, east-central Alaska-Preliminary interpretations: U.S. Geological Survey Bulletin 1999, p. 127-140.

Johnsson, M.J., and Howell, D.G., in press, Thermal maturity map of Alaska: U.S. Geological Survey Miscellaneous Investigations Map.

Johnsson, M.J., Howell, D.G., and Bird, K.J., 1993, Thermal maturity patterns in Alaska-Implications to tectonic evolution and hydrocarbon potential: American Association of Petroleum Geologists Bulletin [in press]. 
Johnsson, M.J., Pawlewicz, M.J., Harris, A.G., and Valin, Z.C., 1992, Vitrinite reflectance and conodont color alteration index data from Alaska-Data to accompany the Thermal Maturity Map of Alaska: U.S. Geological Survey OpenFile Report 92-409, three 3-1/2" diskettes, Macintosh-formatted.

Jones, J.L., and Kilburn, J.E., 1992, Geochemical map showing the distribution of selected elements in heavy-mineral concentrate samples from the Goodnews Bay, Hagemeister Island, and Nushagak Bay quadrangles, Alaska: U.S. Geological Survey Miscellaneous Field Studies Map MF2186, 2 sheets, scale 1:250,000.

Kelley, J.S., Wrucke, C.T., and Armstrong, A.K., 1992, Fracturing and reservoir development in the Katakturuk Dolomite, Arctic National Wildlife Refuge, Alaska [abs.]: U.S. Geological Survey Circular 1074, p. 42-43.

Kelley, K.D., Borden, J.C., Bailey, E.A., Fey, D.L., Motooka, J.M., and Roushey, B.H., 1992, Geochemically anomalous areas in the west-central part of the Howard Pass quadrangle, National Petroleum Reserve, Alaska-Evidence for sediment-hosted $\mathrm{Zn}-\mathrm{Pb}-\mathrm{Ag}-\mathrm{Ba}$ mineralization: U.S. Geological Survey Bulletin 2041, p. 60-69.

Kelley, K.D., and Kelley, D.L., 1992, Reconnaissance exploration geochemistry in the central Brooks Range, northern Alaska-Implications for exploration of sediment-hosted zinc-lead-silver deposits: Journal of Geochemical Exploration, v. 42 , no. $2 / 3$, p. 273-300.

Kilburn, J.E., and Jones, J.L., 1992, Geochemical map showing the distribution of selected elements in stream sediments from the Goodnews Bay, Hagemeister Island, and Nushagak Bay quadrangles, Alaska: U.S. Geological Survey Miscellaneous Field Studies Map MF-23556, 2 sheets, scale 1:250,000.

Kirschner, C.E., Grantz, A., and Mullen, M.W., 1992, Impact origin of the Avak structure, arctic Alaska, and genesis of the Barrow gas fields: American Association of Petroleum Geologists Bulletin, v. 76, no. 5, p. 651-679.

Koch, R.D., Nokleberg, W.J., Zehner, R.E., O'Leary, R.M., Day, G.W., and Sutley, J.S., 1993, Maps and tables showing anomalous levels of selected elements in rock samples from the Mount Hayes quadrangle, eastern Alaska Range, Alaska: U.S. Geological Survey Miscellaneous Investigations Field Studies Map MF-1996-E, 135 p., 5 plates, scale $1: 250,000$ [in press].

Magoon, L.B., 1993a, Kandik province (061): U.S. Geological Survey Bulletin 2034A [in press].

1993b, Alaska interior (062), Kandik (part) (061), Interior lowlands (063), and Copper River Basin (066): U.S. Geological Survey Bulletin 2034A [in press].

1993c, Bristol Basin province (064): U.S. Geological Survey Bulletin 2034A [in press].

1993d, Cook Inlet province (067): U.S. Geological Survey Bulletin 2034A [in press].

Magoon, L.B., and McLean, H., 1993, Alaska Peninsula province (068): U.S. Geological Survey Bulletin 2034A [in press].

McLean, Hugh, and Stanley, R.G., 1992, Reconnaissance sandstone petrology and provenance of the Cantwell Formation, central Alaska: U.S. Geological Survey Bulletin 1999, p. 170-179.
Moore, T.E., Wallace, W.K., Bird, K.J., Karl, S.M., and Mull, C.G., 1992a, Development of the Ellesmerian continental margin and the Brookian orogeny, Alaska-A DNAG perspective [abs.]: U.S. Geological Survey Circular 1074, p. 51-53.

Moore, T.E., Wallace, W.K., Bird, K.J., Karl, S.M., Mull, C.G., and Dillon, J.T., 1992b, Stratigraphy, structure, and geologic synthesis of northern Alaska: U.S. Geological Survey Open-File Report 92-330, 183 p., 1 plate.

Nelson, S.W., 1992, Ophiolitic complexes of the Gulf of Alaska: U.S. Geological Survey Open-File Report 92-020C, 10 p., 1 plate.

Nokleberg, W.J., Aleinikoff, J.N., Lange, I.M., Silva, S.R., Miyaoka, R.T., Schwab, C.E., and Zehner, R.E., 1992, Preliminary geologic map of the Mount Hayes quadrangle, eastern Alaska Range, Alaska: U.S. Geological Survey Open-File Report 92-594, 134 p., 1 sheet, scale 1:250,000.

Nokleberg, W.J., Eremiin, R.A., Byalobzhesky, S.G., Shpikerman, V.I., Siderov, A.A., Rozenblyum, I.S., Ratkin, V.V., Nekrasov, I.Y., and Khanchuk, A.I., 1992, Summary metallogenesis of the Russian Far East [abs.]: Northwest Mining Association Abstracts with Program [in press].

Nokleberg, W.J., Grantz, A., Patton, W.W., Jr., Plafker, G., Scholl, D.W., Tabor, R.W., Vallier, T.L., Fujita, K., Natal'in, B.A., Parfenov, L.M., Khanchuk, A.I., Sokolov, S.D., Tsukanov, N.V., Natapov, L.V., Baranov, B.V., Monger, J.W.H., Gordey, S.P., and Feeney, T.D., 1992a, Circum-North Pacific tectonostratigraphic terrane map [abs.]: 29th International Geological Congress, Kyoto, Japan, 1992, Abstracts, v. 2, p. 153.

1992b, Circum-North Pacific tectonostratigraphic terrane map [abs.]: International Conference on Arctic Margins, Anchorage, Alaska, 1992, ICAM Abstracts, p. 44.

Nokleberg, W.J., Patton, W.W., Jr., and Hearn, P.P., 1991, The Soviet Far East and Alaska: United States Geological Survey Yearbook, Fiscal Year 1990, p. 72-73.

Patton, W.W. Jr., 1992a, Ophiolitic terrane of the western Brooks Range, Alaska: U.S. Geological Survey Open-File Report 92-020D, 8 p., 1 plate.

1992b, Ophiolitic terrane bordering the Yukon-Koyukuk Basin, Alaska: U.S. Geological Survey Open-File Report 92-020F, 8 p., 1 plate.

Patton, W:W. Jr., and Box, S.E., 1992, Ophiolitic terranes of east-central and southwestern Alaska: U.S. Geological Survey Open-File Report 92-020G, 14 p., 2 plates.

Patton, W.W., Jr., Murphy, J.M., Burns, L.E., Nelson, S.W., and Box, S.E., 1992, Geologic map of ophiolitic and associated volcanic arc and metamorphic terranes of Alaska: U.S. Geological Survey Open-File Report 92-020A, 1 sheet, scale 1:2,500,000.

Pavlis, T.L., Sisson, V.B., Foster, H.L., Nokleberg, W.J., and Plafker, G., 1993, Mid-Cretaceous extensional tectonics of the Yukon-Tanana terrane, Trans-Alaskan Crustal Transect (TACT), east-central Alaska: Tectonics v. 12, no. 1, p. 103-122.

Philpotts, John, and Evans, J.R., 1992, Rare earth in "thunder eggs" from Zarembo Island, southeast Alaska: U.S. Geological Survey Bulletin 2041, p. 98-105.

Powers, R.B., ed., 1993, Petroleum exploration plays and resource estimates-Onshore United States: U.S. Geological Survey Bulletin 2034A [in press]. 
Richter, D.H., Duffield, W.A., Sawyer, D.A., Ratte, J.C., and Schmoll, H.R., 1992, Geologic map of the Gulkana A-1 quadrangle, south-central Alaska: U.S. Geological Survey Quadrangle Map GQ-1728 [in press].

Robinson, J.W., and McCabe, P.J., 1992, Reservoir heterogeneities in the Morrison Formation in southern Utah-A Prudhoe Bay analog [abs.]: U.S. Geological Survey Circular 1074, p. 67-68.

Shelton, K.L., Underwood, M.B., Bergfeld, D., and Howell, D.G., 1992, Isotopic variations in calcite veins from the Kandik region of east-central Alaska: U.S. Geological Survey Bulletin 1999, p. 213-221.

Stanley, R.G., Flores, R.M., and Wiley, T.J., 1992, Fluvial facies architecture in the Tertiary Usibelli Group of Suntrana, central Alaska: U.S. Geological Survey Bulletin 1999, p. 204-211.

Stricker, G.D., Tripp, R.B., McHugh, J.B., Affolter, R.H., and Cathrall, J.B., 1992, Gold in the Usibelli Group coals, Nenana Coal Field, Alaska: U.S. Geological Survey Bulletin 2041, p. 93-97.

Taylor, C.D., Cieutat, B.A., and Miller, L.D., 1992, A follow-up geochemical survey of base-metal anomalies in the Ward Creek/Windfall Harbor and Gambier Bay areas, Admiralty Island, southeast Alaska: U.S. Geological Survey Bulletin 2041, p. 86-92.

Underwood, M.B., Brocculeri, T., Bergfeld, D., Howell, D.G., and Pawlewicz, M.J., 1992, Statistical comparison between illite crystallinity and vitrinite reflectance, Kandik region of east-central Alaska: U.S. Geological Survey Bulletin 1999, p. 222-237.

Valin, Z.C., and Collett, T.S., 1992, Molecular and isotopic analyses of the hydrocarbon gases within gas-hydrate-bearing rock units of the Prudhoe Bay-Kuparuk River area in northern Alaska: U.S. Geological Survey Open-File Report 92-299, 90 p.

Watterson, J.R., 1992, Preliminary evidence for the involvement of budding bacteria in the origin of Alaskan placer gold: Geology, v. 20, no. 4 , p. $315-318$.

Weber, F.R., Wheeler, K.L., Rinehart, C.D., Chapman, R.M., and Blodgett, R.B., 1992, Geologic map of the Livengood quadrangle, Alaska: U.S. Geological Survey Open-File Report 92-562, 1 sheet, scale 1:250,000.

Wilson, F.H., Miller, T.P., and Detterman, R.L., 1992, Preliminary geologic map of the Cold Bay and False Pass quadrangles, Alaska Peninsula: U.S. Geological Survey Open-File Report 92-545, 10 p., 1 sheet, scale 1:250,000.

Winkler, G.R., Goldfarb, R.J., and Plafker, G., 1992, The Alaska mineral resource assessment program-Background information to accompany geologic and mineral resource maps of the Valdez quadrangle, south-central Alaska: U.S. Geological Survey Circular 1087, 25 p.

Winkler, G.R., Plafker, G., Goldfarb, R.J., and Case, J.E., 1992, The Alaskan mineral resource assessment program-Background information to accompany geologic and mineralresource maps of the Cordova and Middleton Island quadrangles, southern Alaska: U.S. Geological Survey Circular $1076,81 \mathrm{p}$.

Yeend, Warren, 1992, Experimental abrasion of detrital gold in a tumbler: U.S. Geological Survey Bulletin 2041, p. 70-85.

Yehle, L.A., Schmoll, H.R., and Dobrovolny, E., 1992, Surficial geologic map of the Anchorage A-8 SE quadrangle, Alaska: U.S. Geological Survey Open-File Report 92-350, 35 p., 2 sheets, scale 1:25,000.

\section{U.S. BUREAU OF MINES}

Brodie, M.J., Banta, F.R., and Skermer, N.A., 1992a, RCRA regulation impact on Alaska mineral development tailings management: U.S. Bureau of Mines Open-File Report 94$92,141 \mathrm{p}$.

1992b, RCRA regulation impact on Alaska mineral development waste rock management: U.S. Bureau of Mines Open-File Report 95-92, 99 p.

Brownlow, H.E., 1992, Regulatory processes associated with metal-mine development in British Columbia-A case study of the Snip Mine: U.S. Bureau of Mines Open-File Report 91-92, 49 p.

Burleigh, R.E., 1992, Tin mineralization at the Won prospect, west-central Alaska: U.S. Bureau of Mines Open-File Report 85-92, $21 \mathrm{p}$.

1992, Examination of the Win tin prospect, west-central Alaska: U.S. Bureau of Mines Open-File Report 92-92, 23 p.

Foley, J.Y., 1992, Ophiolitic and other mafic-ultramafic metallogenic provinces in Alaska: U.S. Geological Survey Open-File Report 92-20B, 57 p.

Foley, J.Y., Dahlin, D.C., Mardock, C.L., and O'Connor, W.K., 1992, Reconnaissance investigations of chromite deposits and platinum-group metals in the western Brooks Range, northwestern Alaska: U.S. Bureau of Mines Open-File Report 80-92, $68 \mathrm{p}$.

Gardner, L.A., 1992, Regulatory processes associated with metal-mine development in Alaska-A case study of the Westgold Bima: U.S. Bureau of Mines Open-File Report 88-92, 34 p.

Hemming, J.E., and Cocklan-Vendl, M., 1992, Regulatory processes associated with metal-mine development in AlaskaA case study of the Red Dog Mine: U.S. Bureau of Mines Open-File Report 93-92, 32 p.

Kurtak, J.M., 1992, Searching for minerals above the Arctic Circle: U.S. Bureau of Mines Minerals Today, August 1992, p. 6-10.

Kurtak, J.M., Southworth, D.D., Balen, M.D., and Clautice, K.H., 1992, Mineral investigations in the Valdez Creek mining district, south-central Alaska: U.S. Bureau of Mines Open-File Report 1-92, 658 p.

Maas, K.M., Still, J.C., and Bittenbender, P.E., 1992, Mineral investigations in the Ketchikan mining district, Alaska, 1991-Prince of Wales Island and vicinity: U.S. Bureau of Mines Open-File Report 81-92, 69 p.

McDonald, L.A., and Martin, W.E., 1992, Environmental regulation for mines in southeast Alaska and its effects on projects design, timeframes, and uncertainty-A preliminary review: U.S. Bureau of Mines Open-File Report 10592, $37 \mathrm{p}$.

Meyer, M.P., and Kurtak, J.M., 1992, Results of the 1991 U.S. Bureau of Mines Colville mining district study: U.S. Bureau of Mines Open-File Report 75-92, $101 \mathrm{p}$.

Minerals Today, 1992, Mining claims in Alaska: U.S. Bureau of Mines Minerals Today, February 1992, p. 23.

Summers, C.A., Larson, D.E., and Werdon, M.B., 1993, Lead and zinc mineralization at Story Creek: Society of Mining, Metallurgy, and Exploration Annual Meeting, Reno, Nevada, February 15-18, 1993, Preprint 93-124. 


\section{MINERALS MANAGEMENT SERVICE}

OCS Reports and Maps are authored by the MMS professional staff. OCS Studies are generally contractually prepared environmental, socioeconomic, and technological studies.

Dellagiarino, G., Fulton, P., and Zinzer, D., 1991, Geological and geophysical data acquisition-Outer Continental Shelf through fiscal year 1990: Minerals Management Service OCS Report 91-0092, 67 p.

François, D.K., and Barbagallo, M.B., 1992, Federal offshore statistics-1991: Minerals Management Service OCS Report MMS 92-0056, 163 p.

François, D.K., and Gächter, R.A., 1992, Alaska update, February 1990-April 1992-Outer Continental Shelf oil and gas activities: Minerals Management Service OCS Report MMS 92-0053, 46 p., 2 plates.

Fulton, P.A., 1991, Permitting process for oil, gas, and sulphur on the Outer Continental Shelf: Minerals Management Service OCS Report MMS 91-0059, 17 p. + appendices.

Geiselman, J., and Mitchell, K.L., eds., 1991, Federal arctic research information workshop-Proceedings: Minerals Management Service OCS Study MMS 91-0053, 117 p. + appendices.

Hansen, D.J., 1992, Potential effects of oil spills on marine mammals that occur in Alaskan waters: Minerals Management Service OCS Report MMS 92-0012, 25 p.

Heimberger, M.L., compiler, 1992, Oil \& gas leasing/production program-Annual report, FY 1991: Minerals Management Service OCS Report MMS 92-0059, 77 p.

Herman, B.M., and Zerwick, S.A., 1992, A preliminary analysis of potential field data in the southern Chukchi Sea [abs.]: International Conference on Arctic Margins, Anchorage, Alaska, 1992, ICAM Abstracts, p. 26.

Johnson, P.P., 1992, The North Chukchi high-Compressional structures in a rift system [abs.]: International Conference on Arctic Margins, Anchorage, Alaska, 1992, ICAM Abstracts, p. 28.

Johnson, S.R., and Gazey, W.J., 1992, Design and testing of a monitoring program for Beaufort Sea waterfowl and marine birds: Minerals Management Service OCS Study MMS 92-0060, 114 p.

LGL Ecological Research Associates, 1992, Genetic studies of the Arctic cisco (Coregonus autumnalis) in Alaska-Multiple stocks?: Minerals Management Service OCS Study MMS 92-0039, 151 p.

Lothamer, R.T., 1992, Early Tertiary wrench faulting in the North Chukchi Basin, Chukchi Sea, Alaska [abs.]: International Conference on Arctic Margins, Anchorage, Alaska, 1992, ICAM Abstracts, p. 34.

MBC Applied Environmental Sciences, 1992, Alaska OCS Region, fourth information transfer meeting-Conference proceedings: Minerals Management Service OCS Study MMS 92-0046, 303 p. + appendices.

McGurk, M.D., and Warburton, H. D., 1992, Fisheries oceanography of the southeast Bering Sea-Relationships of growth, dispersion, and mortality of sand lance larvae to environmental conditions in the Port Moller estuary: Minerals Management Service OCS Study MMS 92-0019, 38 p.

McGurk, M.D., Warburton, H. D., Edinger, J.E., and Buchak, E.M., 1991, Fisheries oceanography of the southeast Bering
Sea-Relationships of growth, dispersion, and mortality of herring larvae to environmental conditions in the Port Moller estuary, with appendices to the 1990 annual report: Minerals Management Service OCS Study MMS 92-0018, 58 p. + appendices.

Minerals Management Service, 1992, Alaska regional studies plan-Final, FY 1993: Minerals Management Service, Alaska OCS Region, $167 \mathrm{p}$.

Moore, S.E., and Clarke, J.T., 1992, Distribution, abundance, and behavior of endangered whales in the Alaskan Chukchi and western Beaufort Seas, 1991, with a review 1982-91: Minerals Management Service OCS Study MMS 92-0029, 126 p. + appendices.

Paul, L., and Bascle, B.J., 1992, The Aurora well-Implications for Beaufort Sea and Arctic National Wildlife Refuge (ANWR) geology [abs.]: International Conference on Arctic Margins, Anchorage, Alaska, 1992, ICAM Abstracts, p. 48.

Piatt, J.F., Pinchuk, A., Kitaiskiy, A., Springer, A. M., and Hatch, S.A., 1992, Foraging distribution and feeding ecology of seabirds at the Diomede Islands, Bering StraitsU.S. Fish and Wildlife Service final report: Minerals Management Service OCS Study MMS 92-0041, 133 p.

Schell, D.M., 1992, Stable isotope analysis of 1987-1991 zooplankton samples and bowhead whale tissues: Minerals Management Service OCS Study MMS 92-0020, 101 p.

Scherr, J., Banet, S.M., and Bascle, B.J., 1991, Correlation study of selected exploration wells from the North Slope and Beaufort Sea, Alaska: Minerals Management Service OCS Report MMS 91-0076, 29 p., 19 plates.

1992, Correlation study of selected exploration wells from the North Slope and Beaufort Sea, Alaska [abs.]: International Conference on Arctic Margins, Anchorage, Alaska, 1992, ICAM Abstracts, p. 4.

Sherwood, K.W., 1992, Herald thrust system, southeast Chukchi Sea [abs.]: International Conference on Arctic Margins, Anchorage, Alaska, 1992, ICAM Abstracts, p. 53.

1992, Northeast Chukchi Basin-Suspect Franklinian terrane within Arctic Alaska plate [abs.]: International Conference on Arctic Margins, Anchorage, Alaska, 1992 , ICAM Abstracts, p. 54.

Thorsteinson, L.K., Jarvela, L.E., and Hale, D.A., 1991, Arctic fish habitat use investigations-Nearshore studies in the Alaskan Beaufort Sea, summer 1990: Minerals Management Service OCS Study MMS 92-0011, 166 p.

Tornfelt, E.E., and Burwell, M., 1992, Shipwrecks of the Alaskan shelf and shore: Minerals Management Service OCS Report MMS 92-0002, 227 p.

Tracy, L.M., 1992, Accidents associated with oil and gas operations, Outer Continental Shelf, 1956-1990: Minerals Management Service OCS Report MMS 92-0058, 324 p.

Treacy, S.D., 1992, Aerial surveys of endangered whales in the Beaufort Sea, fall 1991: Minerals Management Service OCS Study MMS 92-0017, 62 p. + appendices.

\section{BUREAU OF LAND MANAGEMENT}

Banet, A.C., Jr., 1992a, Log analysis of Aurora 890-\#1, OCS-Y0943 well, offshore of the Arctic National Wildlife Refuge 1002 Area, northeast Alaska: U.S. Bureau of Land Management, Alaska Technical Report 15, 37 p. 
$1992 \mathrm{~b}$, Geochemical profile and burial history of the Aurora 890 \#1 OCS Y-0943 well offshore of the ANWR 1002 area, northeast Alaska [abs.]: International Conference on Arctic Margins, Anchorage, Alaska, 1992, ICAM Abstracts, p. 3.

-1992c, Log analysis of Aurora 890 \#1, OCS Y-0943 well, offshore of the Arctic National Wildlife Refuge 1002 Area, northeast Alaska [abs.]: International Conference on Arctic Margins, Anchorage, Alaska, 1992, ICAM Abstracts, p. 3.

-1992d, Some geochemical relationships between the oils and extracts of stained sediments from the Prudhoe area, the Bulge, and MacKenzie Delta [abs.]: International Conference on Arctic Margins, Anchorage, Alaska, 1992, ICAM Abstracts, p. 4.

Bascle, R., and Foland, R., 1992, Oil and gas assessment of the Utukok Special Management Area, National Petroleum Reserve in Alaska: U.S. Bureau of Land Management, Alaska Open-File Report 41, 28 p.

Diel, William, 1992, Leasable mineral resource assessment of the South-Central planning area, Alaska: U.S. Bureau of Land Management, Alaska Open-File Report 35, 68 p.

Mowatt, T.C., 1992, Some observations regarding the occurrence of platinum and palladium in mafic-ultramafic igneous rocks, northwestern Alaska [abs.]: International Conference on Arctic Margins, Anchorage, Alaska, 1992, ICAM Abstracts, p. 38.

Mowatt, T.C., and Banet, A., 1992, Petrographic studies of reservoir rock quality and potential, Arctic National Wildlife Refuge (ANWR), northeastern Alaska, part I-Selected outcrop samples [abs.]: International Conference on Arctic Margins, Anchorage, Alaska, 1992, ICAM Abstracts, p. 38.

Mowatt, T.C., Banet, A.C., and Reeder, J.W., 1992a, Petrographic analyses of selected horizons, Aurora 089 No. 1 OCS-Y-0943 well, offshore northeast Alaska, part 1Depth intervals 14,680 feet to 14,860 feet and 16,445 feet to 16,630 feet: U.S. Bureau of Land Management, Alaska Open-File Report 42, 48 p.

1992b, Petrography of selected stratigraphic intervals, Aurora 089 No.1 OCS-Y-0943 well, offshore northeast Alaska [abs.]: International Conference on Arctic Margins, Anchorage, Alaska, 1992, ICAM Abstracts, p. 38.

Mowatt, T.C., Bascle, R., and Gibson, C., 1992, Petrographic studies of reservoir rock quality and potential, Arctic National Widlife Refuge (ANWR), northeastern Alaska, part II-Canning turbidite sequence [abs.]: International Conference on Arctic Margins, Anchorage, Alaska, 1992, ICAM Abstracts, p. 38.

Mowatt, T.C., and Naidu, A.S., 1992a, Gravel-sized sediments from the floor of the Beaufort Sea, offshore northern Alaska, part I-Petrologic character [abs.]: International Conference on Arctic Margins, Anchorage, Alaska, 1992, ICAM Abstracts, p. 37.

1992b, Petrologic character of gravel-sized materials from several coastal/nearshore locations, Beaufort Sea, northern Alaska [abs.]: International Conference on Arctic Margins, Anchorage, Alaska, 1992, ICAM Abstracts, p. 37.

Mowatt, T.C., Seidlitz, A.L., and Dygas, J.A., 1992, The Red Dog ore deposit, northwestern Alaska-A summary of discovery, delineation, and development; Regional resource implications [abs.]: International Conference on Arctic Margins, Anchorage, Alaska, 1992, ICAM Abstracts, p. 39.

\section{U.S. FISH AND WILDLIFE SERVICE}

Natural-resource damage assessment reports relating to the Exxon Valdez oil spill were released in 1992 following the October 1991 settlement of the criminal and civil case against Exxon; the latest interim report is listed. Numerous interim reports for 1990 and (or) 1991 were published in those years but not released until 1992.

Andres, B.A., 1992, Feeding ecology and reproductive success of black oystercatchers in Prince William Sound, revised: Anchorage, Alaska, U.S. Fish and Wildlife Service, Interim Report R0006, 29 p.

Ballachey, B.E., Bodkin, J.L, and Burn, D., 1992, Assessment of the magnitude, extent, and duration of oil spill impacts on sea otter populations in Alaska, revised: Anchorage, Alaska, U.S. Fish and Wildlife Service, Interim Report MM006, 95 p. + appendices.

DeGange, A.R., 1990, Assessment of the fate of sea otters oiled and rehabilitated as a result of the Exxon Valdez oil spill: Anchorage, Alaska, U.S. Fish and Wildlife Service, Interim Report MM007, 13 p. + appendices.

Ecological Consulting, Incorporated, 1991, Assessment of direct seabird mortality in Prince William Sound and the western Gulf of Alaska resulting from the Exxon Valdez oil spill: Anchorage, Alaska, U.S. Fish and Wildlife Service, Final Report BD001, 153 p. + appendices.

Everett, R.J., and Wilmot, R.L., 1990, Genetic stock structure of Arctic char (Salvelinus alpinus) from drainages to the Beaufort Sea in Alaska and Canada: Anchorage, Alaska, U.S. Fish and Wildlife Service, Fisheries Management Services, Alaska Fish and Wildlife Research Center, 59 p.

Felix, N.A., Raynolds, M.K., Jorgenson, J.C., and DuBois, K.E., 1992, Resistance and resilience of tundra plant communities to disturbance by winter seismic vehicles: Arctic and Alpine Research, v. 24 , no. 1 , p. 69-77.

GIS Technical Group, 1991, Natural resource damage assessment report: Anchorage, Alaska, U.S. Fish and Wildlife Service, Interim Report TS003, 77 p.

Hotchkiss, L.A., 1991, Assessment of injury to waterbirds from the Exxon Valdez oil spill-Surveys to determine distribution and abundance of migratory birds in Prince William Sound and the northern Gulf of Alaska: Anchorage, Alaska, U.S. Fish and Wildlife Service, Interim Report BD002A, 79 p. + tables.

Hughes, J.H., 1990, NRDA Status Report-Bird study number 5-Peregrine falcons: Anchorage, Alaska, U.S. Fish and Wildlife Service, Interim Report BD005, 6 p.

Irons, D.B., 1990, Assessment of injury to waterbirds from the Exxon Valdez oil spill-Effects on the reproductive success of black-legged kittiwakes in Prince William Sound: Anchorage, Alaska, U.S. Fish and Wildlife Service, Interim Report BD008, 14 p.

Kuletz, K.J., 1992a, Assessment of injury to nearshore alcids from the Exxon Valdez oil spill-Effects on marbled murrelets and pigeon guillemots-Addendum to bird study 2B: Anchorage, Alaska, U.S. Fish and Wildlife Service, Interim Report BD002B, 15 p.

$1992 \mathrm{~b}$, Interim summary of the 1991 marbled murrelet restoration project, revised: Anchorage, Alaska, U.S. Fish and Wildlife Service, Interim Report R004, 6 p. 
-1992c, Identification of upland habitats used by wildlife affected by the Exxon Valdez oil spill-Marbled murrelets, revised: Anchorage, Alaska, U.S. Fish and Wildlife Service, Interim Report R004, 34 p.

- 1992d, A preliminary summary of the Exxon Valdez damage assessment studies on the pigeon guillemot, revised: Anchorage, Alaska, U.S. Fish and Wildlife Service, Summary Report BD009, 4 p.

1992e, Assessment of injury to marbled murrelets from the Exxon Valdez oil spill-Bird Study Number 6 (1989), includes supplemental to Bird Study No. 2 (1990) and supplemental to Restoration No. 4 (1991), revised: Anchorage, Alaska, U.S. Fish and Wildlife Service, Interim Report BD006, 55 p.

Laing, K.K., 1991, Assessment of injury to waterbirds from the Exxon Valdez oil spill-Boat surveys to determine distribution and abundance of migratory birds in Prince William Sound: Anchorage, Alaska, U.S. Fish and Wildlife Service, Interim Report BD002, $14 \mathrm{p}$.

Lyons, S.M., and Trawicki, J.M., 1991, Water resource inventory and assessment, Arctic National Wildlife Refuge, 1990 stream discharge gaging data: Anchorage, Alaska, U.S. Fish and Wildlife Service, Alaska Fisheries Progress Report 91-2, 12 p.

1992, Water resource inventory and assessment, Arctic National Wildlife Refuge, 1991 stream discharge gaging data: Anchorage, Alaska, U.S. Fish and Wildlife Service, Alaska Fisheries Progress Report 92-2, 12 p.

McCabe, T.R., Griffith, B., Walsh, N.E., and Young, D.D., eds., 1992, Terrestrial research, 1002 area, Arctic National Wildlife Refuge, Interim Report 1988-1990: Anchorage, Alaska, U.S. Fish and Wildlife Service, 432 p.

-1993, Porcupine caribou herd calving site selection-A re-analysis: Canadian Joural of Zoology [in press].

Martin, P.D., 1990, Assessment of injury to shorebird staging and nesting in rocky intertidal habitats of Prince William Sound and the Kodiak Archipelago, Alaska: Anchorage, Alaska, U.S. Fish and Wildlife Service, Interim Report BD012, 53 p.

Monnett, C., and Rotterman, L.M., 1990, Assessment of the fate of sea otters oiled and treated as a result of the Exxon Valdez oil spill: Anchorage, Alaska, U.S. Fish and Wildlife Service, Interim Report MM007, 7 p.

Mueller, K.A., 1992, Toxicity and water quality of natural water bodies, reserve pits, and selected sites at North Slope, Alaska, oil fields: Fairbanks, Alaska, U.S. Fish and Wildlife Service, Technical Report NAES-TR-92-01, 27 p.

Nishimoto, M., 1990. Assessment of injury to waterbirds from the Exxon Valdez oil spill-Effects of petroleum hydrocarbon on fork-tailed storm petrel reproductive success: Anchorage, Alaska, U.S. Fish and Wildlife Service, Interim Report BD007, 21 p.

Nysewander, D., and Dippel, C., 1991, Population surveys of seabird nesting colonies in Prince William Sound, the outside coast of the Kenai Peninsula, Barren Islands, and other nearby colonies, with emphasis on changes of numbers and reproduction of murres: Anchorage, Alaska, U.S. Fish and Wildlife Service, Interim Report BD003, 70 p.

Oakley, K.L., 1990, Effects on the population and reproductive success of pigeon guillemots in Prince William Sound: An- chorage, Alaska, U.S. Fish and Wildlife Service, Final Report BD009, 51 p. + appendices.

Patten, S.M., 1990, Assessment of injury to glaucous-winged gulls using Prince William Sound: Anchorage, Alaska, U.S. Fish and Wildlife Service, Interim Report BD010, 23 p. + appendices.

-1991, Injury assessment of hydrocarbon uptake by sea ducks in Prince William Sound and the Kodiak Archipelago, Alaska: Anchorage, Alaska, U.S. Fish and Wildlife Service, Interim Report BD01 1, 43 p. + tables.

Schempf, P.F., and Bowman, T.D., 1992, Assessing the effect of the Exxon Valdez oil spill on bald eagles-Annual progress report: Anchorage, Alaska, U.S. Fish and Wildlife Service, Interim Report BD004, 66 p.

Sharp, B., 1990, Black oystercatchers in Prince William Sound-Oil spill effects on reproduction and behavior in 1989: Anchorage, Alaska, U.S. Fish and Wildlife Service, Interim Report BD012, 46 p.

Snyder-Conn, E., Bertram, M.R., and Scannell, P.O., 1992, Contaminant data for water, sediments, and fish of Koyukuk National Wildlife Refuge and the northern unit of Innoko National Wildlife Refuge: Fairbanks, Alaska, U.S. Fish and Wildlife Service, Technical Report NAES-TR-92-04, 78 p. + appendices.

Snyder-Conn, E., Mueller, K.A., and Doyle, T.J., 1993, Contaminant baseline data for water, sediments, and fish of the Selawik National Wildlife Refuge, Alaska, 1987-1988: Fairbanks, Alaska, U.S. Fish and Wildlife Service, Technical Report NAES-TR-93-02, 79 p. [in press].

Snyder-Conn, E., Patton, T., Bertram, M.R., Scannell, P.O., and Anthony, C., 1992, Contaminant baseline data for water, sediments, and fish of the Nowitna National Wildlife Refuge, 1985-1988: Fairbanks, Alaska, U.S. Fish and Wildlife Service, Technical Report NAES-TR-92-02, 69 p. + appendices.

Underwood, T.J., Gordon, J.A., and Osborne, B.M., 1992, Fish population characteristics of Arctic National Wildlife Refuge coastal waters, summer 1990: Fairbanks, Alaska, U.S. Fish and Wildlife Service, Alaska Fisheries Progress Report 92-3, $115 \mathrm{p}$.

Walsh, N.E., Fancy, S.G., McCabe, T.R., and Pank, L.F., 1992, Habitat use by the Porcupine Caribou Herd during predicted insect harassment: Journal of Wildlife Management, v. 56, p. $465-473$.

Willms, M.A., 1992, Migratory bird use of potential port sites on the Beaufort Sea coast of the Arctic National Wildlife Refuge: Anchorage, Alaska, U.S. Fish and Wildlife Service, $126 \mathrm{p}$.

Wilson, K.W., 1992, Spatial scales of muskox resource selection in late winter: Fairbanks, Alaska, University of Alaska, M.S. thesis, $90 \mathrm{p}$.

Wiswar, D.W., 1991, Distribution of Arctic fishes in the Okpilak and Akutoktak Rivers, Arctic National Wildlife, Alaska, 1989: Fairbanks, Alaska, U.S. Fish and Wildlife Service, Alaska Fisheries Technical Report 11, 26 p.

1992, Summer distribution of Arctic fishes in the Okpilak, Akutoktak, Katakturuk, and Jago Rivers, Arctic National Wildlife, Alaska, 1990: Fairbanks, Alaska, U.S. Fish and Wildlife Service, Alaska Fisheries Technical Report $17,46 \mathrm{p}$. 
Wohl, K.D., and Denlinger, L.M., 1990, Assessment of injury to waterbirds from the Exxon Valdez oil spill-Beached bird surveys in Prince William Sound and the Gulf of Alaska: Anchorage, Alaska, U.S. Fish and Wildlife Service, Interim Report BD001, 10 p. +3 tables.

\section{DEPARTMENT OF ENERGY}

Pittsburgh Energy Technology Center, 1992, Draft environmental impact statement for the proposed Healy Clean Coal Project: Pittsburgh Energy Technology Center, DOE/EIS0186, $200 \mathrm{p}$.

Watts, K.F., 1992a, Analysis of reservoir heterogeneities due to shallowing-upward cycles in carbonate rocks of the Pennsylvanian Wahoo Limestone of northeastern Alaska-Annual report for the period September 1989-September 1990: Bartlesville, Oklahoma, U.S. Department of Energy, DOE/ BC/14471-11 (DE92001064), 72 p.

$-1992 \mathrm{~b}$, Analysis of reservoir heterogeneities due to shallowing-upward cycles in carbonate rocks of the Pennsylvanian Wahoo Limestone of northeastern Alaska-Annual report for the period September 1990-September 1991: Bartlesville, Oklahoma, U.S. Department of Energy, DOE/ BC/14471-11 (DE92001064), 72 p.

\section{NON-FEDERAL REPORTS}

\section{ALASKA DIVISION OF GEOLOGICAL AND GEOPHYSICAL SURVEYS}

Alaska Department of Natural Resources, 1992, Publications catalog of the Division of Geological and Geophysical Surveys-Interim edition: Alaska Division of Geological and Geophysical Surveys Information Circular 11, 86 p.

Anderson, A.V., and Watts, K.F., 1992, Mangaqtaaq Formation lacustrine(?) deposits in the Endicott Group headwaters of the Kongakut River, eastern Brooks Range, Alaska: Alaska Division of Geological and Geophysical Surveys PublicData File 92-6, 19 p.

Bundtzen, T.K., Miller, M.L., Laird, G.M., and Bull, K.F., 1992, Geology and mineral resources of Iditarod mining district, Iditarod B-4 and eastern B-5 quadrangles, southwestern Alaska: Alaska Division of Geological and Geophysical Surveys Professional Report 97, 46 p., 2 sheets, scale $1: 63,360$.

Bundtzen, T.K., Swainbank, R.C., Wood, J.E., and Clough, A.H., 1992, Alaska's Mineral Industry, 1991: Alaska Division of Geological and Geophysical Surveys Special Report $46,89 \mathrm{p}$.

Clautice, K.H., 1992, Analytical results from the southern Cleveland Peninsula area, Craig C-1 and Ketchikan C-6 quadrangles, southeast Alaska: Alaska Division of Geological and Geophysical Surveys Public Data File 92-22, 6 p.

Combellick, R.A., 1992, The penultimate great earthquake in southcentral Alaska-Evidence from a buried forest near Girdwood: Alaska Division of Geological and Geophysical Surveys Public-Data File 92-12, 11 p.
Gilbert, W.G., Still, J.C., Burns, L.E., Weir, K.R., and Redman, E.C., 1992, Geochemistry of Haines-Klukwan-Porcupine area, southeastern Alaska: Alaska Division of Geological and Geophysical Surveys Report of Investigations 92-5, 75 p., 2 sheets, scale 1:63,360.

LaSage, D.M., 1992, Ground-water resources of the Palmer area, Alaska: Alaska Division of Geological and Geophysical Surveys Report of Investigations 92-3, 39 p., 1 sheet, scale $1: 25,000$.

Munter, J.A., Maurer, M.A., Inghram, M.G., and Petrik, W.A., 1992, Recharge area evaluation for Moonlight Springs, Nome, Alaska: Alaska Division of Geological and Geophysical Surveys Report of Investigations 92-2, 69 p., 2 sheets, scales $1: 63,360$ and $1: 12,000$.

Nye, C.J., Motyka, R.J., Turner, D.L., and Liss, S.A., 1992, Geology and geochemistry of the Geyster Bight geothermal area, Umnak Island, Aleutian Islands, Alaska: Alaska Division of Geological and Geophysical Surveys Report of Investigations 92-1, 85 p., 2 sheets, scale 1:24,000.

Ray, S.R., and Vohden, J., 1992, Investigation of trace metals related to placer mining on Fairbanks \& Porcupine Creeks: Alaska Division of Geological and Geophysical Surveys Public-Data File 92-13, 27 p.

Reger, R.D., ed., 1992, Short notes on Alaskan geology 1991: Alaska Division of Geological and Geophysical Surveys Professional Report 111, 98 p.

Robinson, M.S., Clough, J.G., Roe, J., and Decker, J., 1992, Chronologic variations along the contact between the Echooka Formation and the Lisburne Group in the northeastern Brooks Range, Alaska: Alaska Division of Geological and Geophysical Surveys Public-Data File 92-3, 94 p.

Wallace, W.K., 1992, Detachment folds above a passive-roof duplex-An example from the northeastern Brooks Range, Alaska: Alaska Division of Geological and Geophysical Surveys Public-Data File 92-9, 41 p.

Wood, J.E., 1992, Preliminary results of heavy minerals concentrate analysis from selected interior and western Alaska placer mines: Alaska Division of Geological and Geophysical Surveys Public-Data File 92-2, 7 p.

\section{ADDitional NON-Federal PUblications}

Abrams, M.A., 1992, Geophysical and geochemical evidence for subsurface hydrocarbon leakage in the Bering Sea, Alaska: Marine and Petroleum Geology, v. 9, no. 2, p. 208-221.

Alaska Geographic Society, 1992, Skagway-A legacy of gold: Alaska Geographic, v. 19, no. 1, 96 p.

Cunningham, A.B., Jay, K.L., and Opstad, E., 1992, Unconventioanl Prudhoe Bay wells benefit from NWD use: World Oil, v. 213, no. 5, p. 43-36,38,52.

Gray, I.M., and Hollister, Vic, 1992, Luck or skill?-The discovery of the Fort Knox deposit, Alaska [abs.]: Canadian Mining and Metallurgical (CIM) Bulletin, v. 85, no. 964, p. 86.

Hallam, R.J., Piekenbrock, E.J., Abou-Sayaed, A.S., Garon, A.M., Putnam, T.W., Weggeland, M.C., and Webb, K.J., 1992, Resource description and development potential of the Ugnu reservoir, North Slope, Alaska: SPE Formation Evaluation, v. 7, no. 3, p. 211-218. 
Heylmun, E.B., 1992a, Placer gold near Juneau, Alaska: California Mining Journal, v. 61, no. 8, p. 63-65.

1992b, Rare metal placers, Alaska: California Mining Journal, v. 62, no. 3, p. 26-29.

Huggett, Q.J., Cooper, A.K., Somers, M.L., and Stubbs, A.R., 1992, Interference fringes on GLORIA side-scan sonar images from the Bering Sea and their implications: Marine Geophysical Research, v. 14, no. 1, p. 47-63.

Kaufman, D.S., 1992, Aminostratigraphy of Pliocene-Pleistocene high-sea-level deposits, Nome coastal plain and adjacent nearshore area, Alaska: Geological Society of America Bulletin, v. 104, no. 1, p. 40-52.

Kral, Steve, 1992, Red Dog-Cominco's arctic experience pays off again: Mining Engineering, v. 44, no. 1, p. 43-49.

Lu, Changseng, Reed, M.H., and Misra, K.C., 1992, Zinc-lead skarn mineralization at Tin Creek, Alaska-Fluid inclusions and skarn-forming reactions: Geochimica et Cosmochimica Acta, v. 56, no. 1, p. 109-119.

Mapmakers, 1992, Arctic Slope and Beaufort Sea oil and gas lease map, 1992: Mapmakers, 259 South Alaska Street, Palmer, Alaska 99645, 4 sheets.

Masterson, W. D., and Eggert, J.T., 1992, Kuparuk River fieldU.S.A., North Slope, Alaska, in Foster, N.H., and Beaumont, E.A., compilers, Stratigraphic traps III: Tulsa, Oklahoma, American Association of Petroleum Geologists, Treatise of Petroleum Geology, Atlas of Oil and Gas Fields, p. 257-284.

Metz, Paul, 1992a, Metallogeny of the Fairbanks mining district, Alaska, and adjacent areas of Alaska and the Yukon Territory, Canada [abs.]: 29th International Geological Congress, Kyoto, Japan, 1992, Abstracts, v. 3, p. 742.

-1992b, Porphyry gold occurrences in Alaska [abs.]: 29th International Geological Congress, Kyoto, Japan, 1992, Abstracts, v. 3, p. 728.

Miller, L.D., Barton, C.C., Fredricksen, R.S., and Bressler, J.R., 1992, Structural evolution of the Alaska Juneau lode gold deposit, southeastern Alaska: Canadian Journal of Earth Sciences, v. 29 , no. 5., p. 865-878.

Oil and Gas Journal, 1992 BP revives Niakuk development plan off Alaska's North Slope: Oil and Gas Journal, v. 90, no. 10 , p. 38.

Petroleum Information Corporation, 1992, Special report-1991 annual review, Alaska: Alaska Report, v. 38, no. 9, p. 3-14.

1993, Special report-1992 annual review, Alaska: Alaska Report, v. 39, no. 12, p. 3-16.

Rintoul, Bill, 1992a, Alaska drilling/production: Pacific Oil World, v. 84, no. 1, p. 34-37.

1992b, Alaska update: Pacific Oil World, v. 84 , no. 8 , p. 4-10.

Risley, D.E., Martin, G.C., and Flett, T.O., 1992, Play concepts and petroleum potential of the northcentral Gulf of Alaska continental shelf [abs.]: Geological Society of America Abstracts with Programs, v. 24, no. 5, p. 93.

Sims, D.B., 1992, Relationships of silica, barite, organic material, and sulfide minerals at the Red Dog $\mathrm{Zn}-\mathrm{Pb}-\mathrm{Ag}$ deposit, western Brooks Range, Alaska [abs.]: Geological Society of America Abstracts with Programs, v. 24, no. 7, p. 63.

Skillings Mining Review, 1992, Aspen/Newmont JV undertakes exploration of Alaska gold: Skillings Mining Review, v. 81 , no. 18 , p. 7 .
-1992, Echo Bay files EISs for two Alaska sites: Skillings Mining Review, v. 81, no. 38, p. 13.

Southwestern Paydirt, 1992, Tailings disposal in deep fiord is under study in Alaska: Southwestern Paydirt, no. 642 (December), p. 24A.

Spicer, R.A., Parrish, J.T., and Grant, P.R., 1992, Evolution of vegetation and coal-forming environments in the Late Cretaceous of the North Slope of Alaska, in McCabe, P.J., and Parrish, J.T., eds., Controls on the distribution and quality of Cretaceous coals: Geological Society of America Special Paper 267, p. 177-192.

Watkinson, D.H., and Melling, D.R., 1992, Hydrothermal origin of platinum-group mineralization in low-temperature copper sulfide-rich assemblages, Salt Chuck intrusion, Alaska: Economic Geology, v. 87, no. 1, p. 175-184.

Wirth, K.R., and Bird, J.M., 1992, Chronology of ophiolite crystallization, detachment, and emplacement-Evidence from the Brooks Range, Alaska: Geology, v. 20, no. 1, p. 75-78.

Yu, Z., and Lerche, Ian, 1992, An integrated quantitative basin analysis study of the northern part of the Arctic National Wildlife Refuge, northeastern Alaska: Journal of Geodynamics, v. 15, no 1/2, p. 107-146.

Yu, Z., Li, Y., and Lerche, I., 1992, Thermal history and hydrocarbon maturity study in the Norton basin, Alaska: Energy, Exploration, and Exploitation, v. 10, no. 6, p. 402-421.

\section{APPENDIX 2.-ROLES OF FEDERAL AGENCIES IN MINERAL PROGRAMS}

\section{DEPARTMENT OF THE INTERIOR}

\section{U.S. GEOLOGICAL SURVEY}

The mission of the USGS is to develop and interpret the geologic, topographic, and hydrologic data necessary for prudent management of the Nation's minerals, land, and water. The USGS carries out its mission through research that produces geographic, cartographic, and remotely sensed information; geologic, geochemical, and geophysical maps and studies; energy, mineral, and water resource assessments; geohazards research, including toxic waste studies; and participation in multidisciplinary projects, maintaining data bases, and publishing reports and maps.

In Alaska, the USGS is active in assessing minerals, including metalliferous and energy resources. Field and laboratory researchers also gather information about domestic petroleum, coal, uranium, and geothermal resources. At the request of landmanaging agencies, the USGS provides mineral-resource assessments for land planning, including wilderness studies. Within Alaska, the USGS maintains offices for its Geologic, National Mapping, and Water Resources Divisions. Within the Geologic Division, the Branch of Alaskan Geology is the primary USGS office studying mineral resources in Alaska; the Branch is headquartered in Anchorage with a field office in Fairbanks. Other Alaska Branch geologists are stationed in Menlo Park, California. During the summer field season, many USGS scientists from other branches within the Geologic Division conduct mineral-related research in Alaska. 


\section{U.S. BUREAU OF MINES}

The mission of the USBM is to help ensure that our country has an adequate, dependable supply of minerals and materials to meet its national security and economic needs at acceptable social, environmental, and economic costs. The USBM's Alaska Field Operations Center (AFOC) has headquarters in Anchorage and offices in Juneau and Fairbanks. The AFOC carries out its mission through five programs:

1. Minerals availability program.-This program is part of a worldwide USBM program responsible for developing the Minerals Availability System (MAS) computer data base and the Mineral Industry Location System (MILS), a subset of MAS. MILS contains basic information about the identification and location of known mineral deposits. MAS is more extensive, containing information about reserve estimates, mineral extraction and beneficiation methodologies, environmental constraints to mining, and cost analyses for selected major mineral deposits. A computer and communication system allow the information to be stored, manipulated, and retrieved as computer-plotted map overlays and printouts of MAS/MILS data, enabling rapid and uniform development of cost data for MAS mineral-deposit evaluations. MAS and MILS mineral-deposit data are cross-indexed to several other minerals-information data bases.

2. Policy analysis.-This program emphasizes the analysis of newly developed and existing mineral data to interpret their significance in the context of local and national mineral needs. Assessment of technical, institutional, political, social, and economic factors that affect the supply of, and demand for, domestic and international minerals is the key to identifying mineral issues.

3. State mineral activities.-This program covers mineralsrelated activities in Alaska and assists in developing and releasing nonfuel-mineral-industry information. The program also provides the USBM with direct communication to the ADGGS, the Alaska Division of Mining, other minerals-oriented government agencies, industry, private firms, and individuals. The USBM's State Mineral Officer collects, analyzes, and reports mineral data and develops information regarding activities and trends in the mining industry. This program produces the annual USBM Minerals Yearbook chapters and Mineral Industry Surveys.

4. Mineral land assessment.-This is the USBM's major Alaskan program, conducted in cooperation with other Federal and State agencies. Mineral assessments are both areal and commodity-oriented. In support of the Secretary of the Interior's commitment to assess the mineral potential of public lands in Alaska, the AFOC initiated a program in 1985 to evaluate mineral resources of the mining districts in the State. The program seeks to identify the type, amount, and distribution of mineral deposits; related studies will determine their economic feasibility. Legislative effects on mineral development will also be addressed. The USBM has completed its study of the Juneau and Valdez Creek mining districts; studies of the Colville and Ketchikan mining districts are in progress. The USBM also provides minerals data in support of USFS activities in Alaska. The USBM acts as a mineral information resource in support of USFS planning statewide and assists the USFS in identification of mine hazards.

A statewide program provides an inventory and specific technical evaluations of Alaska's strategic and critical mineral and advanced material deposits on Federal lands that are closed to mineral entry, and on lands that are open to entry but not of current interest to industry. In addition to locating, mapping, and estimating the size and grade of deposits, the USBM obtains bulk samples for metallurgic research to determine recovery and extraction methods and costs. These studies are undertaken in cooperation with the USBM Research Centers in Albany, Oregon, and Salt Lake City, Utah. These investigations provide reserve estimates of marginal and submarginal deposits in Alaska and its coastal waters.

5. Minerals research.-The USBM is attempting to provide solutions to mining, mineral recovery, and environmental problems in Alaska through a number of research efforts and technology transfer. Several research projects are currently being conducted in Alaska by USBM research centers or at universities sponsored by the USBM's Mineral Institute Program. USBM and university research centers cooperate with the AFOC to solve mineral utilization problems.

\section{MINERALS MANAGEMENT SERVICE}

The MMS was created in 1982 with a twofold mission: (1) to collect and disburse revenues generated from mineral leases on Federal and Indian lands, and (2) to oversee the orderly development of America's offshore energy and mineral resources while properly safeguarding the environment. The MMS supervises mineral leasing, exploration, development, and production on the OCS. It is responsible for oil-rig safety, oil-rig pollution control regulations, determination of the environmental impact of resource development, and estimation of oil and gas resources. The MMS also has the authority to lease the OCS for ocean mining of hard minerals. At present, revenues from the Alaska OCS are primarily derived from competitive leasing activities; no development or production is occurring on the OCS at this time. The responsibility of the MMS for onshore Alaskan minerals is limited to the collection of royalties, bonuses, and rents from Federal and certain Native lands.

The MMS holds Synthesis Meetings and Information Transfer Meetings, Regional Technical Working Group Meetings, Coordination Team Meetings, and public hearings on Environmental Impact Statements. To determine public concerns for consideration and inclusion in EIS's, scoping meetings related to specific planning or subject areas are held in the local villages. The public is invited to attend these meetings and can contact the MMS Regional Office for specific subjects, dates, and times.

In Alaska, the MMS is active in assessing the oil and gas potential of offshore basins through the analysis of geophysical and geologic data. This work is integrated into the National Resource Assessment and is a basis for evaluations of the potential monetary worth of individual OCS lease blocks, for appraisals of the resource potential of entire basins, and for the formulation of geologic models of basin development. The MMS conducts specialized studies of geologic and geophysical data obtained from deep stratigraphic test (DST) wells and exploratory wells drilled on OCS lands. The results of these studies are published through the MMS OCS Report series or in appropriate scientific journals. The MMS also sponsors resource-oriented geologic studies through the Program for Studies Related to Continental Margins, which funds research by State agencies and affiliated academic institutions. 


\section{BUREAU OF LAND MANAGEMENT}

The BLM manages Federal onshore mineral resources. The BLM also works cooperatively with the NPS, FWS, and USFS to provide technical evaluation of the mineral-related issues on lands under these agencies' jurisdiction.

Management decisions concerning all minerals on the 92 million acres of land currently managed by the BLM in Alaska (fig. 1) are made through the Resource Management Planning process. The BLM first identifies the mineral potential of each planning unit. The effects of minerals exploration, development, and production, and land abandonment and rehabilitation are then analyzed in regard to the needs and sensitivities of the other resources present. Mitigation measures are developed and evaluated to reduce or avoid adverse impacts of the anticipated mineral activities. Field monitoring of all phases of mineral activity ensures that no unnecessary or undue degradation occurs. The BLM also provides resource management for retained Federal mineral estates on an additional 100 million acres.

\section{U.S. FISH AND WILDLIFE SERVICE}

The FWS provides Federal leadership to conserve, protect, and enhance fish and wildlife and their habitats for the continuing benefit of people. In Alaska, the FWS seeks to accomplish this mission through programs that implement provisions of the Endangered Species Act, Marine Mammal Protection Act, Fish and Wildlife Coordination Act, National Wildlife Refuge System Administration Act, ANILCA, Rivers and Harbors Act, Clean Water Act, various migratory-bird laws and treaties, and other statutes.

Under ANILCA, 16 refuges in Alaska (fig. 5) were created or enlarged to conserve fish and wildlife populations and their habitats, as well as other values. Except for valid rights existing at the time of establishment, these refuges are closed to entry and location under mining laws. The refuges are open to entry under leasing laws but are closed to the mining of coal by the Federal Coal Leasing Amendments Act of 1975 and are closed to geothermal resource leasing by the Geothermal Steam Act of 1970. Although many traditional activities have been deemed appropriate for these refuges, other uses, including oil and gas leasing, will be permitted only when such activities are compatible with the purposes for which a specific refuge was established.

\section{NATIONAL PARK SERVICE}

In 1916, Congress established the National Park Service and stated that the fundamental purpose of the Nation's parks, monuments, and other reservations was "to conserve the scenery and natural and historical objects and the wildlife therein and to provide for the enjoyment of same in such a manner and by such means as will leave them unimpaired for the enjoyment of future generations" (39 Stat. 535). NPS management policies are based on the concept of conservation and preservation while providing for appropriate enjoyment of natural and cultural resources within the park system.

Congress enacted the "Mining in the Parks" Act in 1976, declaring that a continued application of the mining laws of the United States to park units conflicts with the purposes for which the parks were established and that all mining operations in park units "should be conducted so as to prevent or minimize damage to the environment and the other resource values" (90 Stat. 1342). The NPS manages mining activities on park lands through regulations found at Title 36 CFR, Part 9, Subpart A. These regulations apply to mining-related activities on patented or valid unpatented claims located under the Mining Law of 1872, and proposed plans of operations for such claims must conform to the statutes. Regulations at Title $36 \mathrm{CFR}$, Part 9, Subpart B govern non-Federal oil and gas development. Pursuant to the permitting and coordination requirements of Title 36 CFR, Part 9, Subpart D, eligible Federal agencies may conduct AMRAP activities in units of the National Park System.

\section{DEPARTMENT OF AGRICULTURE}

\section{U.S. FOREST SERVICE}

The mission of the USFS is to provide a continuing flow of natural-resource goods, including mineral and energy resources, to help meet national needs, and to contribute to meeting such needs worldwide. It is the responsibility of the USFS to encourage and support environmentally sound mineral enterprises on Federal lands under its administration. In managing the use of these resources, the USFS objective is to minimize unnecessary adverse environmental impacts to surface and cultural features and values that might result from lawful exploration and development operations. This objective is accomplished through the application of reasonable conditions that do not interfere with well-planned mineral operations. The USFS also provides research information and technology to help with post-mining reclamation. In implementing this policy, the USFS Chief directed that:

1. A key objective of the minerals program is to encourage and facilitate the orderly exploration, development, and production of mineral resources.

2. Minerals, like range, recreation, timber, water, wildlife, and wilderness, are one of the multiple uses that the USFS manages.

3. USFS managers must develop a good understanding of the minerals industry, its practices, and the minerals laws and regulations.

4. Managers must develop a strong working relationship with the minerals industry.

5. Visibility and interaction with the minerals industry must be increased by attendance and participation of line officers and appropriate staff at industry and professional association activities and meetings.

6. Directories, organization charts, and receptionists direct the mineral industry to personnel who have minerals-administration responsibilities.

\section{DEPARTMENT OF ENERGY}

The DOE's mission is to reduce the Nation's vulnerability to disruptions of energy supplies and to mitigate any adverse impacts on the Nation should a shortage occur. With regard to Alaska, the energy sources currently being addressed by the DOE are fossil fuels (petroleum and coal) and geothermal. 
The strategy for responding to petroleum-supply interruptions is to rely on the free market, supplemented as necessary and appropriate with other measures, such as the Strategic Petroleum Reserve. The DOE's Fossil Energy Research and Development Programs are aimed at careful consideration of the alternatives available and the relative chances for success in fostering an adequate supply of energy at a reasonable cost through long-term, high-risk research and development. Alternatives for increasing domestic petroleum supplies include (1) DOE's Unconventional Gas Recovery Program, which emphasizes the development of advanced technologies for the extraction of natural gas from resources that are classified as unconventional because of unique geologic settings and production mechanisms that are not now well understood; and (2) DOE programs for developing tertiary oil recovery, tar sands, and heavy-oil deposits.

The purpose of the DOE's Geothermal Energy Program is to develop the technology needed by industry for the use of geothermal resources. DOE research is aimed toward improving methods used to locate, extract, and convert geothermal heat to usable forms of energy. Through DOE funding in Alaska, Federal and State agencies have researched and published several studies of specific geothermal systems.

A further purpose of DOE programs is to generate data essential to the private sector's decision-making process to facilitate the development of commercial projects. 


\section{SELECTED SERIES OF U.S. GEOLOGICAL SURVEY PUBLICATIONS}

\section{Periodicals}

Earthquakes \& Volcanoes (issued bimonthly).

Preliminary Determination of Epicenters (issued monthly).

\section{Technical Books and Reports}

Professional Papers are mainly comprehensive scientific reports of wide and lasting interest and importance to professional scientists and engineers. Included are reports on the results of resource studies and of topographic, hydrologic, and geologic investigations. They also include collections of related papers addressing different aspects of a single scientific topic.

Bulletins contain significant data and interpretations that are of lasting scientific interest but are generally more limited in scope or geographic coverage than Professional Papers. They include the results of resource studies and of geologic and topographic investigations, as well as collections of short papers related to a specific topic.

Water-Supply Papers are comprehensive reports that present significant interpretive results of hydrologic investigations of wide interest to professional geologists, hydrologists, and engineers. The series covers investigations in all phases of hydrology, including hydrogeology, availability of water, quality of water, and use of water.

Circulars present administrative information or important scientific information of wide popular interest in a format designed for distribution at no cost to the public. Information is usually of shortterm interest.

Water-Resource Investigations Reports are papers of an interpretive nature made available to the public outside the formal USGS publications series. Copies are reproduced on request unlike formal USGS publications, and they are also available for public inspection at depositories indicated in USGS catalogs.

Open-File Reports include unpublished manuscript reports, maps, and other material that are made available for public consultation at depositories. They are a nonpermanent form of publication that may be cited in other publications as sources of information.

\section{Maps}

Geologic Quadrangle Maps are multicolor geologic maps on topographic bases in 7 1/2-or 15 -minute quadrangle formats (scales mainly $1: 24,000$ or $1: 62,500$ ) showing bedrock, surficial, or engineering geology. Maps generally include brief texts; some maps include structure and columnar sections only.

Geophysical Investigations Maps are on topographic or planimetric bases at various scales; they show results of surveys using geophysical techniques, such as gravity, magnetic, seismic, or radioactivity, which reflect subsurface structures that are of economic or geologic significance. Many maps include correlations with the geology.

Miscellaneous Investigations Series Maps are on planimetric or topographic bases of regular and irregular areas at various scales; they present a wide variety of format and subject matter. The series also includes 7.1/2-minute quadrangle photogeologic maps on planimetric bases that show geology as interpreted from aerial photographs. Series also includes maps of Mars and the Moon.
Coal Investigations Maps are geologic maps on topographic or planimetric bases at various scales showing bedrock or surficial geology, stratigraphy, and structural relations in certain coal-resource areas.

Oil and Gas Investigations Charts show stratigraphic information for certain oil and gas fields and other areas having petroleum potential.

Miscellaneous Field Studies Maps are multicolor or black-andwhite maps on topographic or planimetric bases on quadrangle or irregular areas at various scales. Pre-1971 maps show bedrock geology in relation to specific mining or mineral-deposit problems; post-1971 maps are primarily black-and-white maps on various subjects, such as environmental studies or wilderness mineral investigations.

Hydrologic Investigations Atlases are multicolor or black-andwhite maps on topographic or planimetric bases presenting a wide range of geohydrologic data of both regular and irregular areas; principal scale is $1: 24,000$, and regional studies are at $1: 250,000$ scale or smaller.

\section{Catalogs}

Permanent catalogs, as well as some others, giving comprehensive listings of U.S. Geological Survey publications are available under the conditions indicated below from the U.S. Geological Survey, Books and Open-File Reports Sales, Federal Center, Box 25286, Denver, CO 80225. (See latest Price and Availability List.)

"Publications of the Geological Survey, 1879-1961" may be purchased by mail and over the counter in paperback book form and as a set of microfiche.

"Publications of the Geological Survey, 1962-1970" may be purchased by mail and over the counter in paperback book form and as a set of microfiche.

"Publications of the Geological Survey, 1971-1981" may be purchased by mail and over the counter in paperback book form (two volumes, publications listing and index) and as a set of microfiche.

Supplements for 1982, 1983, 1984, 1985, 1986, and for subsequent years since the last permanent catalog may be purchased by mail and over the counter in paperback book form.

State catalogs, "List of U.S. Geological Survey Geologic and Water-Supply Reports and Maps For (State)," may be purchased by mail and over the counter in paperback booklet form only.

"Price and A vailability List of U.S. Geological Survey Publications," issued annually, is available free of charge in paperback booklet form only.

Selected copies of a monthly catalog "New Publications of the U.S. Geological Survey" are available free of charge by mail or may be obtained over the counter in paperback booklet form only. Those wishing a free subscription to the monthly catalog "New Publications of the U.S. Geological Survey" should write to the U.S. Geological Survey, 582 National Center, Reston, VA 22092.

Note.-Prices of Government publications listed in older catalogs, announcements, and publications may be incorrect. Therefore, the prices charged may differ from the prices in catalogs, announcements, and publications. 
